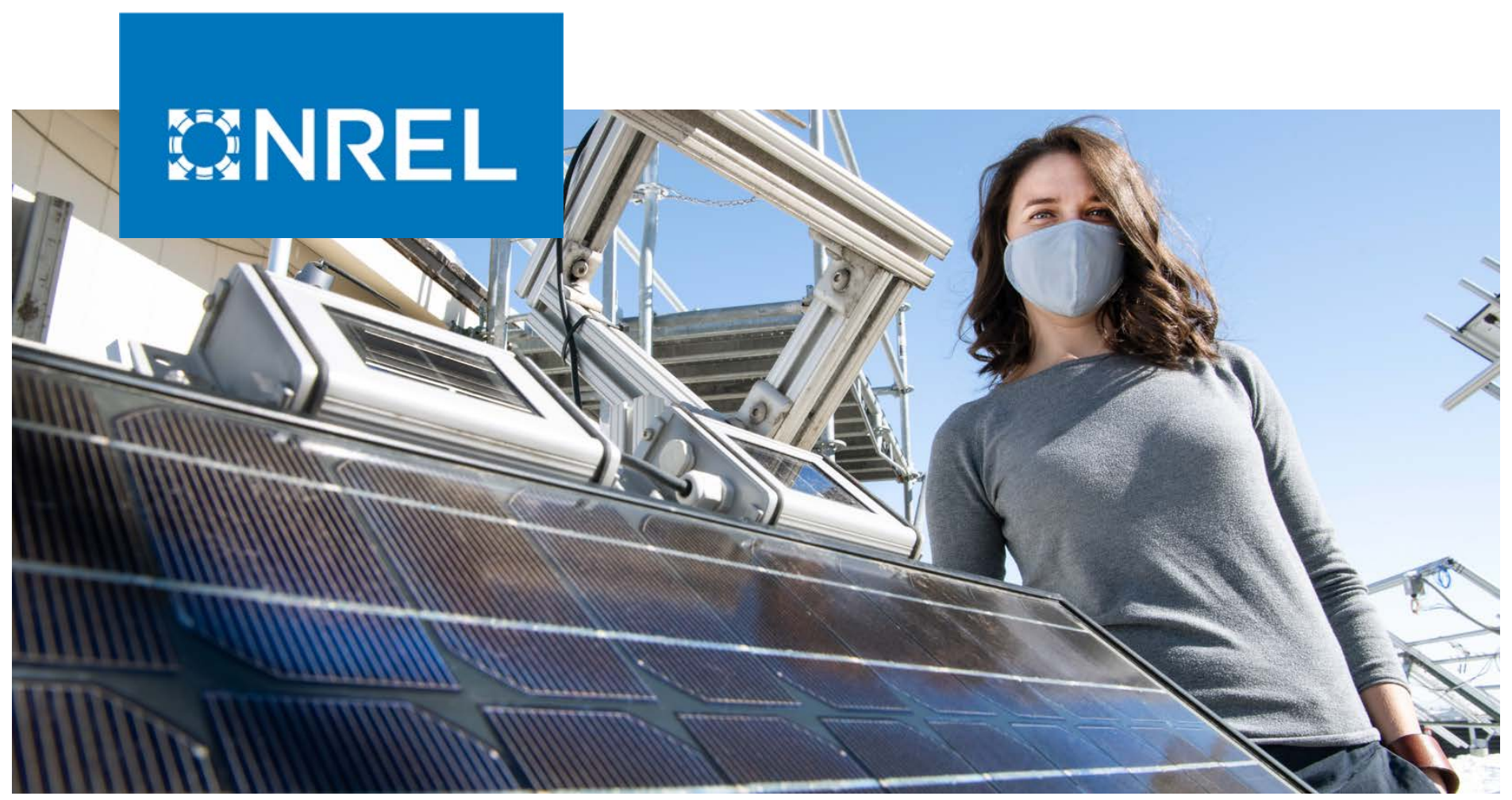

\title{
Photovoltaic (PV) Module Technologies: 2020 Benchmark Costs and Technology Evolution Framework Results
}

Brittany L. Smith, ${ }^{1}$ Michael Woodhouse, ${ }^{1}$

Kelsey A. W. Horowitz, ${ }^{1}$ Timothy J. Silverman, ${ }^{1}$

Jarett Zuboy, ${ }^{2}$ and Robert M. Margolis ${ }^{1}$

1 National Renewable Energy Laboratory

2 Independent Contractor

NREL is a national laboratory of the U.S. Department of Energy Office of Energy Efficiency \& Renewable Energy

Operated by the Alliance for Sustainable Energy, LLC

This report is available at no cost from the National Renewable Energy Laboratory (NREL) at www.nrel.gov/publications.
Technical Report

NREL/TP-7A40-78173

November 2021 


\title{
GNREL
}

\section{Photovoltaic (PV) Module Technologies: 2020 Benchmark Costs and Technology Evolution Framework Results}

\author{
Brittany L. Smith, ${ }^{1}$ Michael Woodhouse, ${ }^{1}$ \\ Kelsey A. W. Horowitz, ${ }^{1}$ Timothy J. Silverman, ${ }^{1}$ \\ Jarett Zuboy, ${ }^{2}$ and Robert M. Margolis ${ }^{1}$ \\ 1 National Renewable Energy Laboratory \\ 2 Independent Contractor
}

\section{Suggested Citation}

Smith, Brittany L., Michael Woodhouse, Kelsey A. W. Horowitz, Timothy J. Silverman, Jarett Zuboy, and Robert M. Margolis. 2021. Photovoltaic (PV) Module Technologies: 2020

Benchmark Costs and Technology Evolution Framework Results. Golden, CO: National

Renewable Energy Laboratory. NREL/TP-7A40-78173.

https://www.nrel.gov/docs/fy22osti/78173.pdf.

NREL is a national laboratory of the U.S. Department of Energy Office of Energy Efficiency \& Renewable Energy Operated by the Alliance for Sustainable Energy, LLC

This report is available at no cost from the National Renewable Energy Laboratory (NREL) at www.nrel.gov/publications.

Contract No. DE-AC36-08GO28308
Technical Report

NREL/TP-7A40-78173

November 2021

National Renewable Energy Laboratory 15013 Denver West Parkway Golden, CO 80401

303-275-3000 • www.nrel.gov 


\section{NOTICE}

This work was authored by the National Renewable Energy Laboratory, operated by Alliance for Sustainable Energy, LLC, for the U.S. Department of Energy (DOE) under Contract No. DE-AC36-08GO28308. Funding provided by the U.S. Department of Energy Office of Energy Efficiency and Renewable Energy Solar Energy Technologies Office. The views expressed herein do not necessarily represent the views of the DOE or the U.S. Government.

This report is available at no cost from the National Renewable

Energy Laboratory (NREL) at www.nrel.gov/publications.

U.S. Department of Energy (DOE) reports produced after 1991 and a growing number of pre-1991 documents are available free via www.OSTI.gov.

Cover Photo by Dennis Schroeder: NREL 62765.

NREL prints on paper that contains recycled content. 


\section{Acknowledgments}

This work received funding from the Solar Energy Technologies Office (SETO) of the U.S. Department of Energy (DOE). We acknowledge the following people for their useful contributions, corrections, comments, and review: David Albin (NREL), Paul Basore (DOE), Brion Bob (DOE), Andrew Dawson (DOE), Joel Jean (Swift Solar), Becca Jones-Albertus (DOE), Katsumi Kushiya (Idemitsu Kosan), and Lenny Tinker (DOE). We also thank Alfred Hicks (NREL) for the many wonderful graphics. 


\section{List of Acronyms}

2J

ALD

AM

AR

ARC

AZO

BSF

C60

CapEx

CBD

CdTe

CIGS

CNBM

COGS

c-Si

$\mathrm{Cz}$

CZTS

DC

DHA

DMSO

EBIT

EH44

EPFL

ETL

EVA

FA

FAI

FF

FTO

GAAP

GM

HTAB

HTL

HVPE

IBC

IEC

IFRS

IPA

ISCAS

ISE

ISFH

ITO

I-V

$\mathrm{iZnO}$ two-junction

atomic layer deposition

atmospheres

antireflection

antireflection coating

aluminum zinc oxide

back surface field

carbon-60

capital expenditures

chemical bath deposition

cadmium telluride

copper indium gallium (di)selenide

Chinese National Building Material Company

cost of goods sold

crystalline silicon

Czochralski

copper zinc tin diselenide

direct current

double-layered halide architecture

dimethyl sulfoxide

earnings before interest and taxes

9-(2-ethylhexyl)- $N, N, N, N$-tetrakis(4-methoxyphenyl)-

$9 H$-carbazole-2,7-diamine

Ecole polytechnique federale de Lausanne

electron transport layer

ethylene-vinyl acetate

formamidinium

formamidinium iodide

fill factor

fluorine-doped tin oxide

Generally Accepted Accounting Principles

gross margin

$n$-hexyl trimethyl ammonium bromide

hole transport layer

hydride vapor phase epitaxy

interdigitated back contact

International Electrotechnical Commission

International Financial Reporting Standards

isopropyl alcohol

Institute of Semiconductors in the Chinese Academy of Sciences

Fraunhofer Institute for Solar Energy Systems

Institute for Solar Energy Research in Hamelin

indium tin oxide

current-voltage

intrinsically doped zinc oxide 


\begin{tabular}{|c|c|}
\hline J-box & junction box \\
\hline $\mathrm{J}_{\mathrm{sc}}$ & short-circuit current \\
\hline $\mathrm{J}-\mathrm{V}$ & current density-voltage \\
\hline KRICT & Korea Research Institute of Chemical Technology \\
\hline LCOE & levelized cost of electricity \\
\hline LID & light-induced degradation \\
\hline MA & methylammonium \\
\hline MAI & methylammonium iodide \\
\hline MOCVD & metal organic chemical vapor deposition \\
\hline MOVPE & metal organic vapor phase epitaxy \\
\hline MSP & minimum sustainable price \\
\hline MWT & metal wrap through \\
\hline NREL & National Renewable Energy Laboratory \\
\hline OpEx & operating expenses \\
\hline P3HT & poly(3-hexylthiophene) \\
\hline PCBM & methanofullerene phenyl-C61-butyric-acid-methyl-ester \\
\hline PEAI & phenethylammonium iodide \\
\hline PECVD & plasma-enhanced chemical vapor deposition \\
\hline PERC & passivated emitter and rear cell \\
\hline PERL & passivated emitter rear locally diffused \\
\hline PERT & passivated emitter rear totally diffused \\
\hline PET & polyethylene terephthalate \\
\hline POE & polyolefin \\
\hline PSG & phosphosilicate glass \\
\hline PTAA & poly(triarylamine) \\
\hline PV & photovoltaic(s) \\
\hline PVCS & photovoltaic combining switchgear \\
\hline $\mathrm{R} \& \mathrm{D}$ & research and development \\
\hline $\mathrm{R} 2 \mathrm{R}$ & roll-to-roll \\
\hline RTP & rapid thermal processing \\
\hline $\mathrm{S} 2 \mathrm{~S}$ & sheet-to-sheet \\
\hline SAS & selenization and sulfurization \\
\hline SG\&A & sales, general, and administrative \\
\hline SHJ & silicon heterojunction \\
\hline SJ & single-junction \\
\hline spiro-OMeTAD & 2,2',7,7'-tetrakis(N,N-di-p-methoxyphenlamine)-9,9'spirobifluorene \\
\hline STC & standard test conditions \\
\hline $\mathrm{TCO}$ & transparent conducting oxide \\
\hline TEF & technology evolution framework \\
\hline $\mathrm{TJ}$ & triple-junction \\
\hline TMAl & trimethyl aluminum \\
\hline TMGa & trimethyl gallium \\
\hline TMIn & trimethyl indium \\
\hline USD & U.S. dollars \\
\hline $\mathrm{V}_{\text {oc }}$ & open-circuit voltage \\
\hline wph & wafers per hour \\
\hline
\end{tabular}




\section{Executive Summary}

In 2016, the U.S. Department of Energy's Solar Energy Technologies Office set a goal to reduce the unsubsidized levelized cost of electricity (LCOE) of utility-scale photovoltaics (PV) to 3 cents/kWh by 2030. Utility PV systems were benchmarked to have an LCOE of approximately 5 cents/kWh in 2020 (Feldman, Ramasamy et al. 2021). To achieve the 2030 SunShot goal, the lifetime economics of PV systems must be improved across multiple dimensions. One key aspect is module minimum sustainable price (MSP), which we benchmark in this report via bottom-up manufacturing cost analysis, applying a gross margin of $15 \%$ to approximate the minimum rate of return necessary to sustain a business over the long term. Figure ES-1 summarizes our MSP benchmarks for established PV technologies in mass production. Technologies based on crystalline silicon (c-Si) dominate the current PV market, and their MSPs are the lowest; the figure only shows the MSP for monocrystalline monofacial passivated emitter and rear cell (PERC) modules, but benchmark MSPs are similar $(\$ 0.25-\$ 0.27 / \mathrm{W})$ across the c-Si technologies we analyze. Cadmium telluride (CdTe) modules have a slightly higher MSP $(\$ 0.28 / \mathrm{W})$, and the copper indium gallium (di)selenide (CIGS) MSP represents a larger step up $(\$ 0.48 / \mathrm{W})$, largely owing to higher labor and equipment/facility costs.

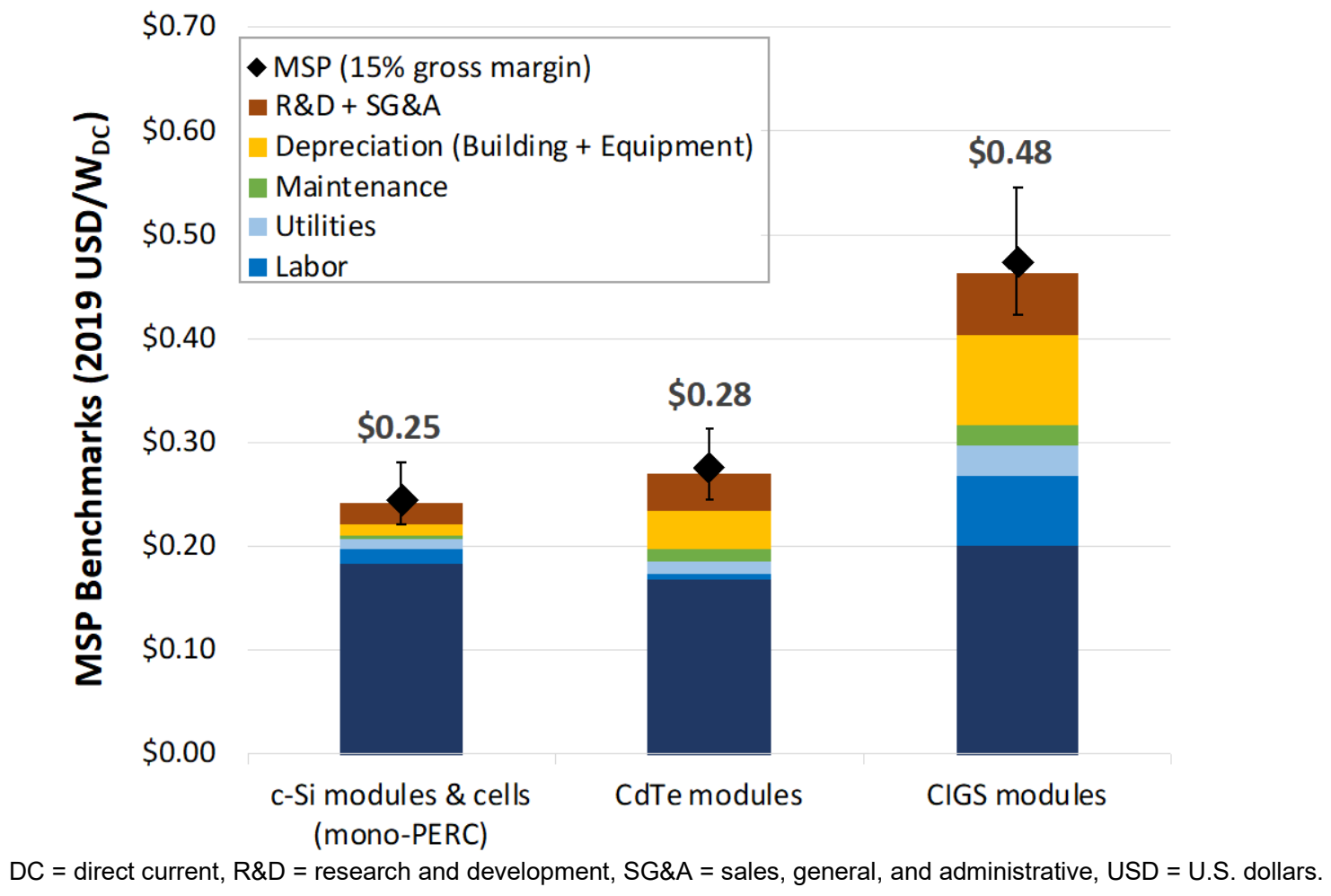

Figure ES-1. Summary of module MSPs for established PV technologies, 2020

We provide technology roadmaps to additional MSP reductions for these PV technologies, which are summarized in Figure ES-2. The MSPs for c-Si and CdTe modules stay similar to each other over the short and long term, while the CIGS premium shrinks but remains significant.

We also separately consider III-V and perovskite PV technologies, which are currently in smallscale or pilot production. This report represents our first technoeconomic assessment of perovskite PV. As shown in Figure ES-3, the III-V MSP benchmark is two orders of magnitude 
higher $(\$ 77 / \mathrm{W})$ than the benchmarks for established technologies, and to date such high prices have kept III-V technology in niche markets including space and terrestrial concentrator applications. This challenge is reflected in the III-V roadmap, in which several potential cost reductions still result in a long-term projection of $\$ 20 / \mathrm{W}$, two orders of magnitude higher than the long-term MSPs of the other technologies. The single-junction sheet-to-sheet (S2S) perovskite module MSP estimated at small production scale is $\$ 0.38 / \mathrm{W}$, with potential cost reductions over the long term achieving $\$ 0.18 / \mathrm{W}$ if performance is able to be improved without incurring additional costs (Figure ES-3). Perovskites can also be combined with other PV technologies in multijunction configurations. We estimate an MSP of \$0.31/W for perovskite-onSi tandem modules in early production based on pilot production results, and this technology could benefit from progress along both the perovskite and c-Si roadmaps.

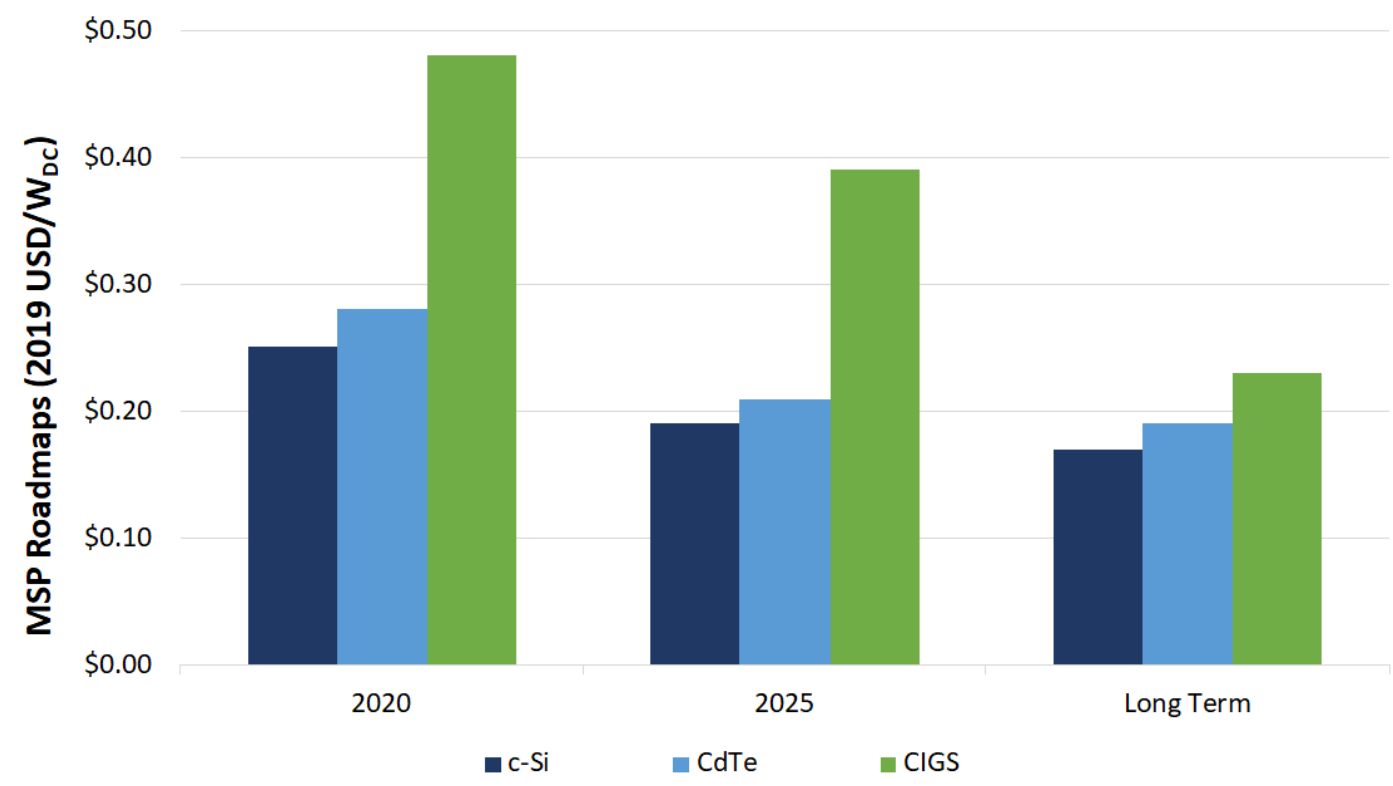

Figure ES-2. Summary of projected module MSPs for established PV technologies, assuming $15 \%$ gross margin

The costs captured in our MSP results represent only some of the factors that determine actual module selling prices. Cost reductions related to production scale-up (economies of scale) and the accumulation of manufacturing experience (learning by doing) are important, but they are not estimated in our cost-reduction roadmaps. Other important module price drivers not captured in our bottom-up analysis include global supply and demand fluctuations, domestic policies related to PV deployment and manufacturing, trade policies, and corporate strategies. Comparing our bottom-up module MSP results with module market prices helps illuminate these other drivers. 

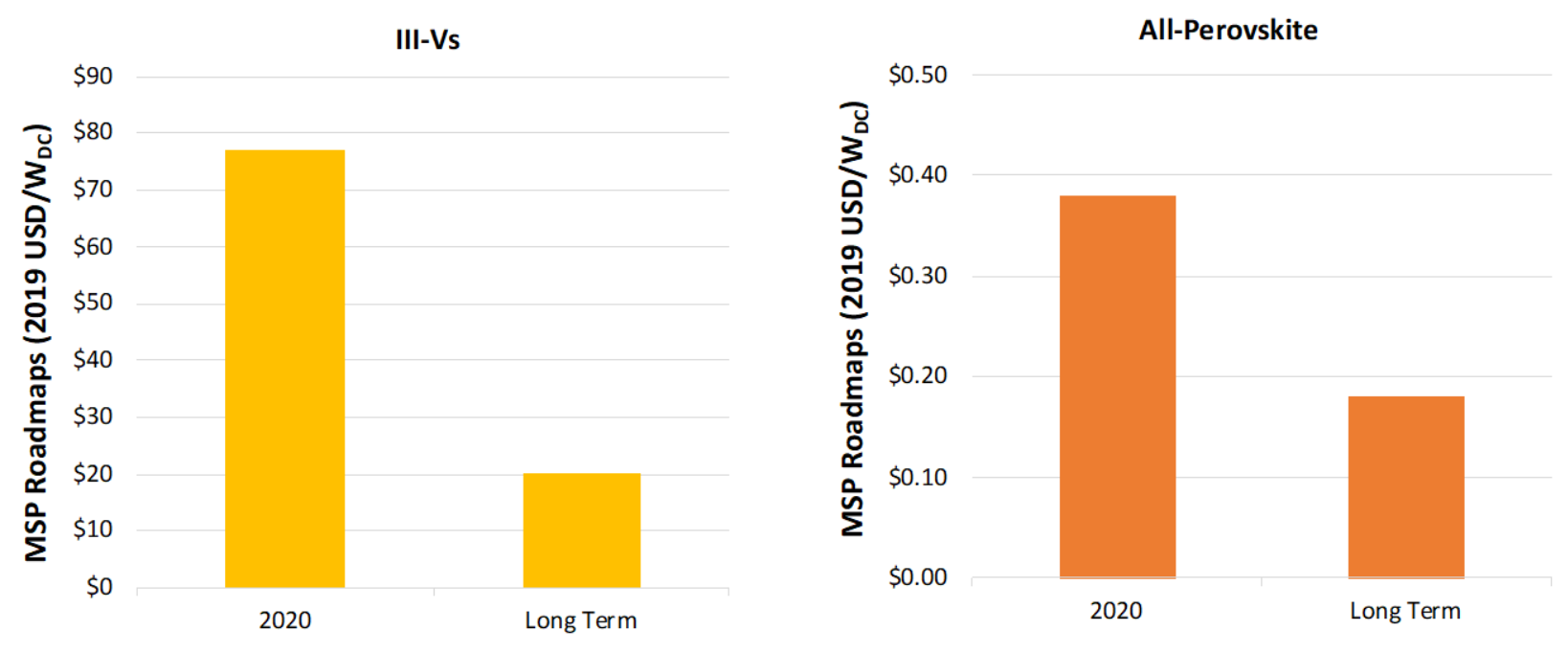

Figure ES-3. Estimated MSPs for III-V and all-perovskite PV technologies

Finally, this report uses a technology evolution framework (TEF) to analyze drivers of LCOE reductions, including installed system cost which is heavily influenced by module price. TEF results are mapped onto radar plots with three axes, including system cost, service life, and annual energy yield. The units for each metric $\left(\$ / \mathrm{m}^{2}\right.$ for system cost, $\mathrm{kWh} / \mathrm{m}^{2}$ for annual energy, and years for service life) prevent effects on LCOE from being double counted. The system cost axis is inverted to be consistent with the other metrics: a value farther from the center represents a lower LCOE. The gray concentric contours shown in the background of the plot represent equilateral positions on each axis, and each concentric contour proceeding outward represents approximately $10,5,2$, and 1 cents/kWh LCOE, respectively. For each technology, the 2030 values target an LCOE of 3 cents $/ \mathrm{kWh}$ while accounting for the known strengths and limitations of each technology.

Plots are shown in Figure ES-4 for CdTe, CIGS, III-V, perovskite, and multiple c-Si PV technologies assuming single-axis tracker utility-scale PV systems under Kansas City insolation. This TEF analysis highlights technology-specific challenges and opportunities related to achieving the 3 cents $/ \mathrm{kWh}$ LCOE target by 2030 . CdTe and c-Si technologies are likely to achieve higher efficiencies by 2030, which increases the annual energy yield and alleviates the system cost reductions required to achieve the 2030 LCOE target. In contrast, CIGS systems require larger cost reductions owing to limits on annual energy yield caused by the challenges evident in achieving higher CIGS efficiencies. Similarly, both III-V and perovskite technologies require large system cost reductions to achieve the 2030 LCOE target: the III-Vs because their exceptional energy yield and service life potential cannot fully offset their extremely high current system cost, and perovskites because they currently have the shortest service life among all technologies. 
mono PERC

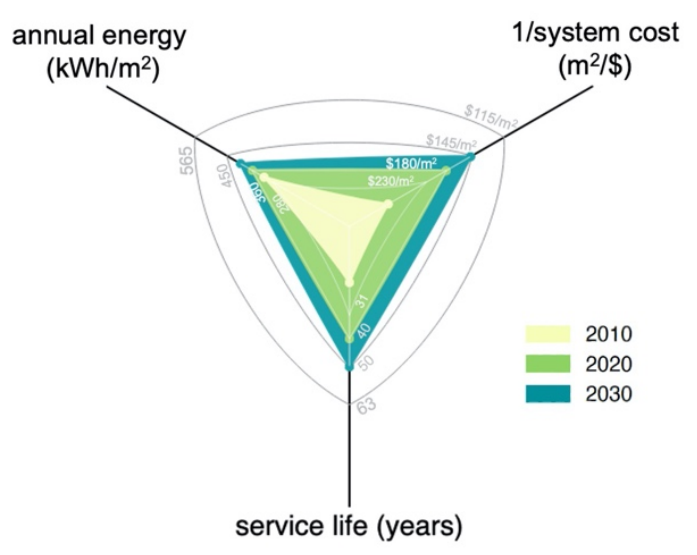

\section{CdTe}

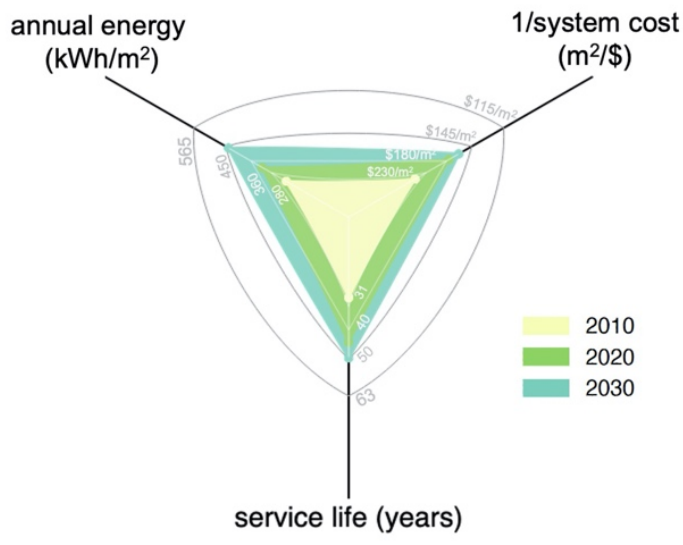

III-Vs

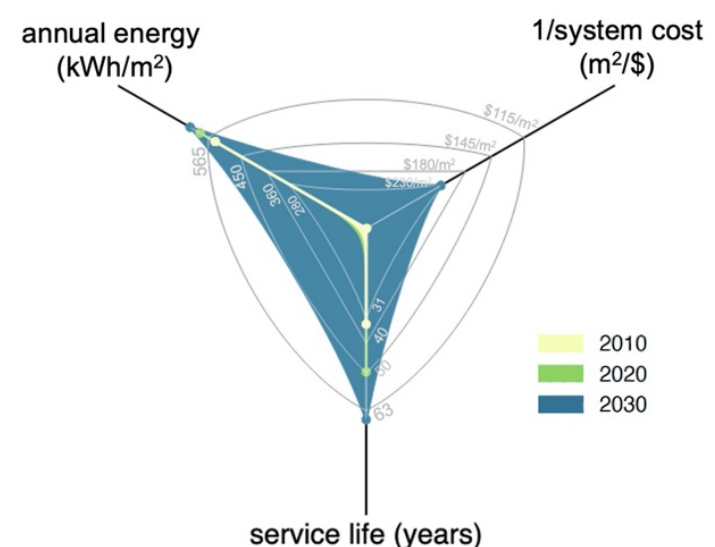

bifacial SHJ

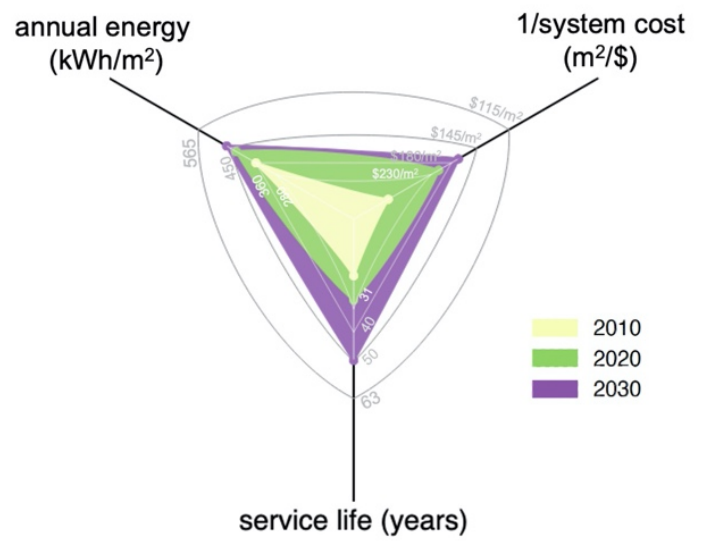

CIGS

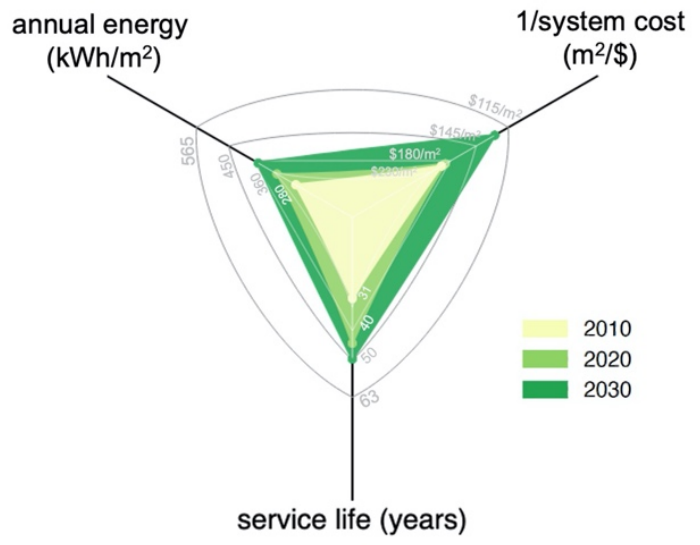

perovskites

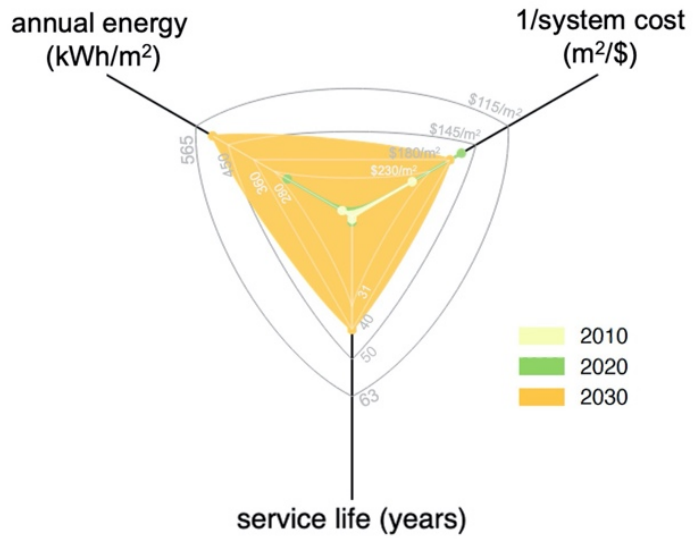

$\mathrm{SHJ}=$ silicon heterojunction .

Figure ES-4. TEF results for various PV technologies

ix 


\section{Table of Contents}

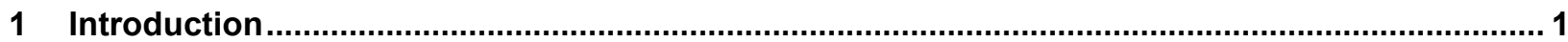

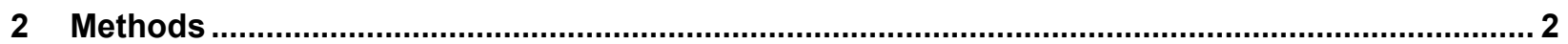

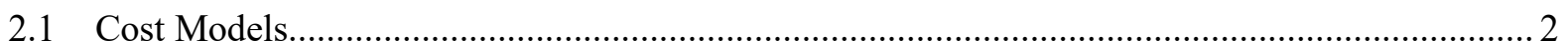

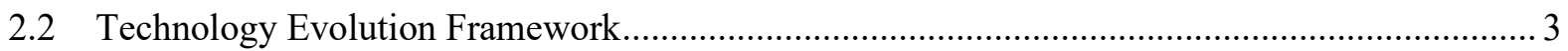

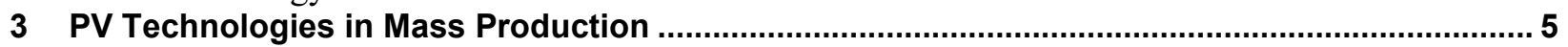

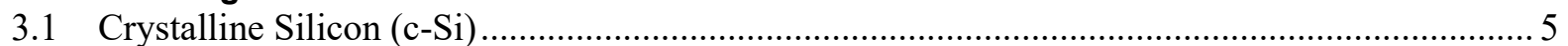

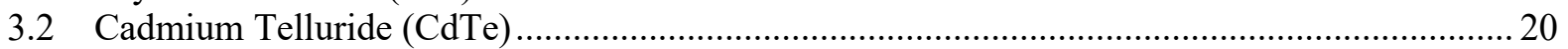

3.3 Copper Indium Gallium (Di)selenide (CIGS) …........................................................ 26

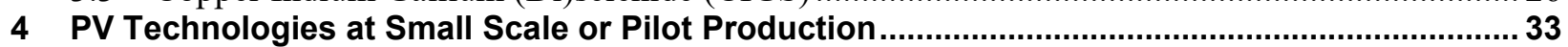

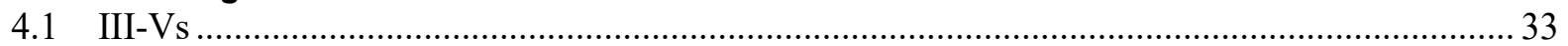

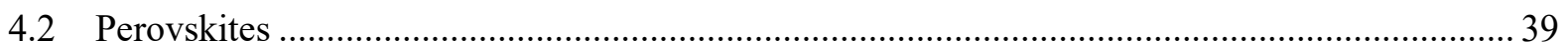

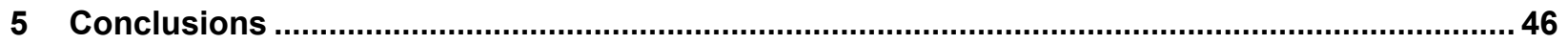

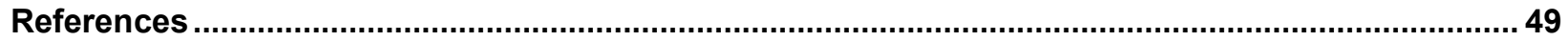

Appendix 


\section{List of Figures}

Figure 1. Cost modeling methods and technologies covered in this report ............................................. 2

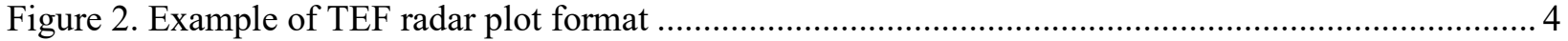

Figure 3. Major steps in the c-Si supply chain (Woodhouse, Smith, et al. 2019) ..................................... 6

Figure 4. c-Si device designs: p-type (PERC) and n-type (IBC, PERT/PERL, and SHJ) .......................... 7

Figure 5. c-Si cell and module efficiency progress......................................................................... 9

Figure 6. Typical process flow for manufacturing monocrystalline (left) and multicrystalline (right) PERC

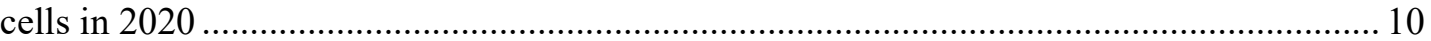

Figure 7. Process flow for manufacturing standard PERC modules................................................... 11

Figure 8. Step-by-step costs for monocrystalline PERC cell production in urban China, 2020 ............... 13

Figure 9. Step-by-step costs for monocrystalline PERC module assembly in urban China, 2020 ............. 14

Figure 10. Cell benchmark MSPs by c-Si technology .................................................................... 15

Figure 11. Fixed and variable costs for monocrystalline p-type wafer production, PERC cell conversion,

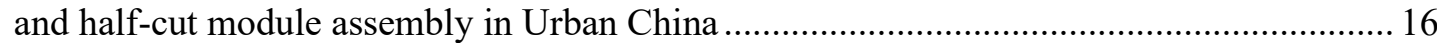

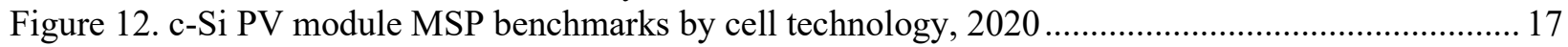

Figure 13. Technology roadmap with projected MSPs for monocrystalline Si modules, assuming 15\%

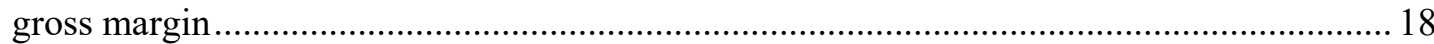

Figure 14. TEF plots for c-Si PV systems: monofacial monocrystalline PERC, bifacial monocrystalline PERC, IBC, bifacial PERT/PERL, and bifacial SHJ ........................................................ 19

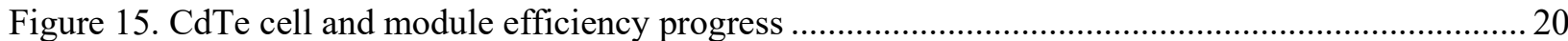

Figure 16. Device stack for CdTe cells built by monolithic integration .................................................. 21

Figure 17. Process flow used for NREL's CdTe manufacturing cost model ............................................ 22

Figure 18. Costs aggregated by major steps for Series 6 CdTe module production in Southeast Asia, 2-

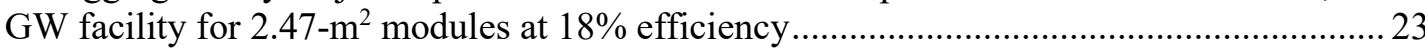

Figure 19. CdTe PV module MSP benchmark for production in Southeast Asia, 2020 ........................ 24

Figure 20. Technology roadmap with projected MSPs for CdTe modules, assuming 15\% gross margin.. 25

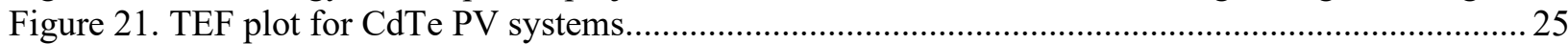

Figure 22. Different CIGS device stacks used today (thicknesses of individual layers can vary)............. 27

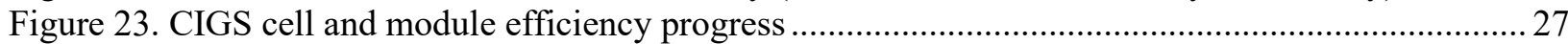

Figure 24. Process flows for manufacturing glass-glass monolithic CIGS modules ................................ 28

Figure 25. Step-by-step costs for CIGS reference design A, where the CIGS layer is produced using the

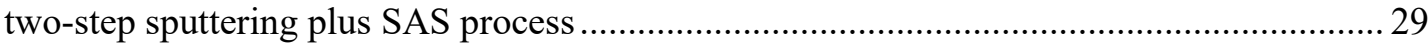

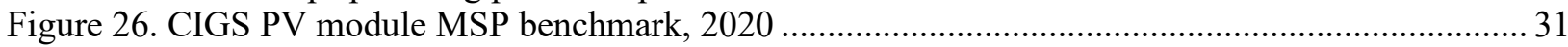

Figure 27. Technology roadmap with projected MSPs for CIGS modules, assuming a 15\% gross margin

.

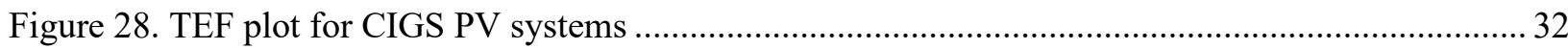

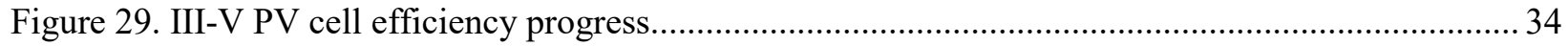

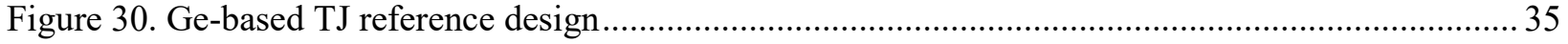

Figure 31. Process flow for Ge-based TJ cell .................................................................................. 35

Figure 32. Step-by-step costs for MOVPE growth of TJ III-V cell on Ge substrate in the United States,

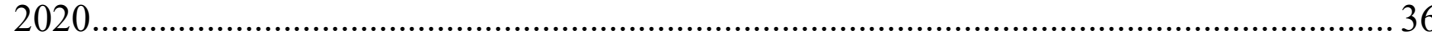

Figure 33. MSP benchmark for TJ III-V cell on Ge substrate, U.S. production, 2020 .......................... 37

Figure 34. Technology roadmap with projected MSPs for TJ III-V cells, assuming $15 \%$ gross margin.... 38

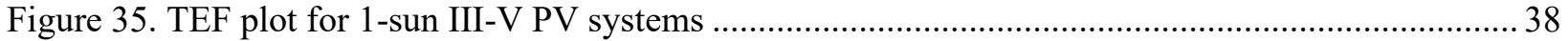

Figure 36. Efficiency progress for early-stage PV technologies including perovskites .......................... 40

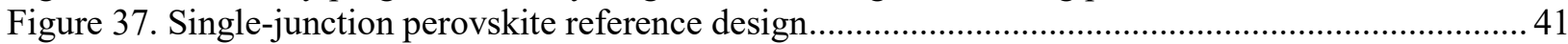

Figure 38. Process flow for S2S single-junction perovskite module .................................................. 41

Figure 39. Step-by-step costs for S2S single-junction perovskite module manufacturing in the United

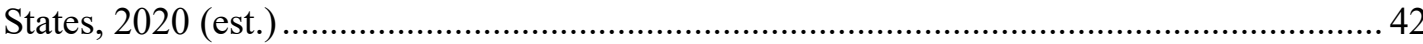

Figure 40. Process flow for perovskite-on-Si tandem cell .......................................................................... 42 
Figure 41. Step-by-step costs for perovskite-on-Si tandem module manufacturing in the United States, 2020 (est.)...

Figure 42. Estimated costs and MSPs for single-junction S2S perovskite module and technology roadmap, assuming $15 \%$ gross margin

Figure 43. Estimated costs and MSP for perovskite-on-Si tandem module production in the United States

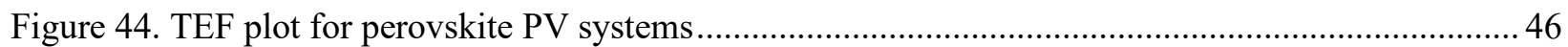

Figure 45. Summary of MSPs for established PV technologies, 2020 .............................................. 47

Figure 46. Summary of projected module MSPs for established PV technologies, assuming 15\% gross

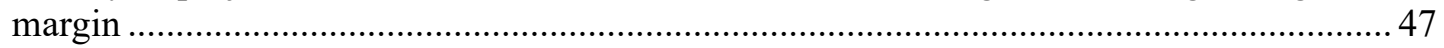

Figure 47. Estimated MSPs for III-V and all-perovskite PV technologies .............................................. 48

\section{List of Tables}

Table 1. c-Si PV Metrics Relevant to Production Scale and Energy Yield ............................................... 8

Table 2. Overview of Inputs Used in NREL's PERC Cost Models........................................................ 12

Table 3. Summary of Global CdTe Module Manufacturing and Cumulative Installations in 2020 ...........20

Table 4. Summary of Inputs Used in NREL's CdTe Module Cost Model ............................................. 23

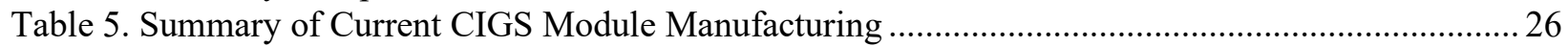

Table 6. Summary of Inputs Used in NREL's CIGS Module Cost Model............................................... 30

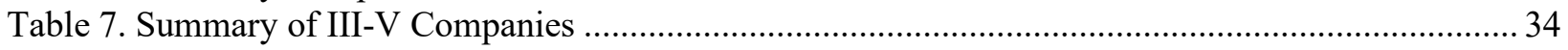

Table 8. Overview of Inputs Used in NREL's III-V Cost Models .......................................................... 36

Table 9. Overview of CapEx Differences for Rigid S2S vs. Flexible Roll-to-Roll (R2R) Single-Junction

Perovskite Modules, Assuming the Same Efficiency (16\%) ............................................... 39

Table 10. Overview of Inputs Used in NREL's Single-Junction Perovskite and Perovskite-on-Si Tandem

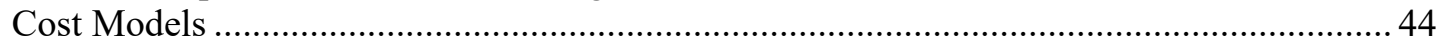




\section{Introduction}

Photovoltaic (PV) module prices are a key metric for PV project development and growth of the PV industry. The general trend of global PV module pricing has been a rapid and steep declinean order of magnitude over the past 10 years (Mints April 2019) — enabled by economies of scale as well as manufacturing and technology improvements. Along the way, there have been shortterm price fluctuations, primarily driven by supply-chain bottlenecks such as the polysilicon supply shortages and price shocks around 2008 (DOE 2012). Most recently, changes in deployment and manufacturing incentives have been driving global surpluses or shortfalls across the PV supply chain. Some changes are driven by different deployment targets set in key markets or changes in feed-in tariff rates or tax incentives. Trade tariffs of varying forms also have influenced pricing across the PV supply chain.

Because China is the world's largest PV producer and consumer, availability and pricing for modules has become highly dependent upon the PV deployment targets and feed-in tariff rates set by the New Energy Administration in China's Ministry of Energy. Specific module vendors and power ratings have even had their supply-demand dynamics determined by specifications in China's "Top Runner" programs (although this program is expected to wind down in 2020 as policies are steered more toward grid parity above all else).

The demand for modules outside of China has depended most heavily on changes in feed-in tariff rates from Japan, India, and countries in the European Union. Optimal timing for monetizing the investment tax credit in the United States has also played a significant role recently. Numerous countries continue to experiment with anti-dumping duties against selected countries and/or impose domestic-content requirements for new PV installations. One net impact of these tariffs and policy measures has been to diversify manufacturing across the globe. They have also greatly impacted module pricing in various nuanced ways.

The National Renewable Energy Laboratory (NREL) tracks high-level policy drivers that affect module supply-demand dynamics and price while assessing the profitability of PV manufacturing by comparing market prices to bottom-up module manufacturing cost model results, which also clarifies cost drivers in the PV supply chain. This report contains the most recent results from our crystalline-silicon (c-Si), cadmium telluride $(\mathrm{CdTe})$, copper indium gallium (di)selenide (CIGS), and III-V PV cell models as well as our first technoeconomic assessment of perovskite PV. These cost assessments update a comprehensive review of the methods, input data, and cost model results for the c-Si supply chain in 2018 (Goodrich, Hacke et al. 2013, Woodhouse, Smith et al. 2019), and they update cost model results from a roadmap for III-V cells (Horowitz, Remo et al. 2018).

This report also uses a technology evolution framework (TEF) to detail system cost, service life, and annual energy yield for each PV technology over time, with projections into the future. Service life plays a crucial role in the economics of PV systems (Jones-Albertus, Feldman et al. 2016, Woodhouse, Jones-Albertus et al. 2016). Higher-efficiency modules can reduce balanceof-system costs (Fu, Feldman et al. 2018), and any additional energy-yield benefits offered by a particular technology may reduce the levelized cost of energy (LCOE) (Woodhouse, Marion et al. 2019). 


\section{Methods}

In this section, both the cost model methodology and TEF methodology used in this report are described.

\subsection{Cost Models}

Figure 1 summarizes our overall procedure for creating PV cost models. On the left side, the technologies currently included in our bottom-up module manufacturing cost analysis portfolio are listed. Detailed documentation of the manufacturing process for each technology is required to identify and collect the data necessary for the cost model. In the center, specific manufacturing data inputs that must be collected for the model are listed. To quantify the metrics associated with large-scale manufacturing, we work with relevant materials and equipment suppliers and integrated manufacturers from across the globe.

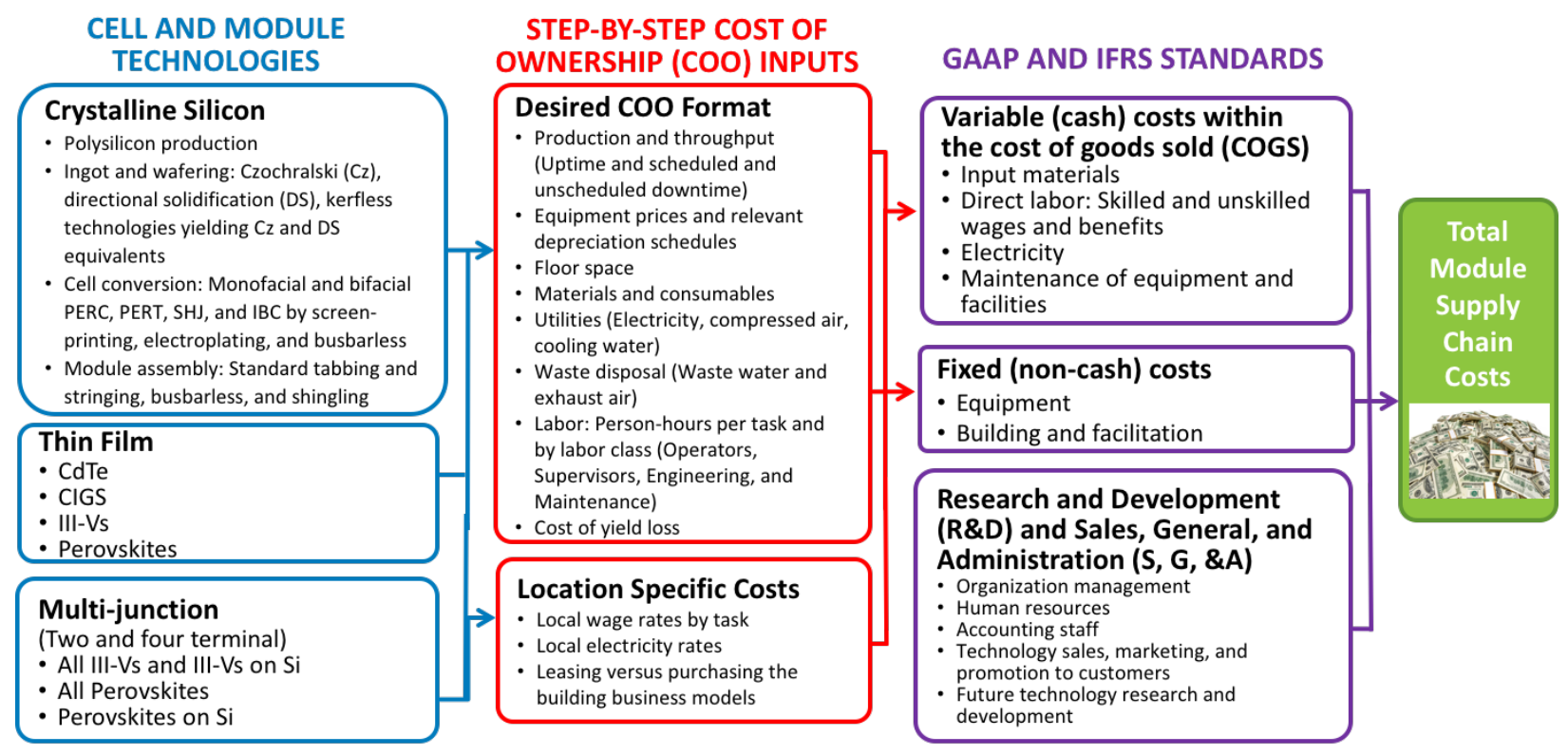

Figure 1. Cost modeling methods and technologies covered in this report

The right side of Figure 1 summarizes the structure of the cost outputs. We report our cost model results as per the U.S. Generally Accepted Accounting Principles (GAAP) and the International Financial Reporting Standards (IFRS) (Woodhouse, Smith et al. 2019). Variable costs (or "cash" costs) within the cost of goods sold (COGS) include raw materials converted into finished product, all direct costs for manufacturing labor, equipment- and building-related electricity, and maintenance-related spare parts or labor. Working capital - the cash available to a firm at a point in time - typically pays for these items.

Fixed costs are also included in COGS; typically, for PV manufacturing, these costs are reported on a depreciated basis following a linear yearly schedule. The initial investments are called capital expenditures (CapEx), and depreciation expenses can be used as tax deductions during the period that defines the equipment's useful lifetime. The depreciation period is 5-10 years for PV manufacturing equipment and 15-25 years for purchased (not leased) buildings and other facilities. If a linear or straight-line schedule is used, CapEx can be converted into an average per-watt depreciation expense by dividing the total investment by the annual production (in watts 
per year) and assumed useful lifetime (in years). We assume manufacturing equipment will have no residual value and, after its depreciation schedule, must be replaced, which seems consistent with the rate of technology obsolescence observed in the PV industry.

For publicly traded firms, the fixed and variable costs that constitute COGS are generally reported after each accounting period (often based on a full fiscal year or a quarter). Depending on the activity type and the relevant tax codes, research and development (R\&D) expenses can be paid with working capital — as an expense during the present accounting period — or amortized over more than one accounting period. Sales, general, and administrative (SG\&A) expenses are generally expensed as incurred in a given accounting period; these include overhead personnel costs as well as other costs related to administration including compensation for accounting staff, human resources, and executives.

The resources and staff dedicated to SG\&A and R\&D differ substantially across firms, which increases the difficulty of bottom-up cost modeling for these elements. To estimate these expenses, we rely on industry-aggregated statistics derived from publicly listed company income statements, which generally report SG\&A and R\&D costs as line items separate from COGS. Using the income statements of the top 11 publicly traded PV firms in 2019, we calculate SG\&A expenses as $9.2 \% \pm 1.9 \%$ of revenues and $R \& D$ expenses as $2.8 \% \pm 0.7 \%$ of revenues with $90 \%$ confidence intervals (Feldman and Margolis 2020). For this reason, we calculate overhead expenses assuming SG\&A expenses of $9 \%$ of revenues and R\&D expenses of $3 \%$ of revenues throughout the remainder of the report.

The output quantity labeled "total module supply chain costs" is distinct from the module selling price. To estimate the selling price, an operating margin must be applied to account for profit and the corporate tax rate, as well as interest and dividend payments (the cost of capital). The operating margin, R\&D expenses, and SG\&A expenses together constitute the gross margin. Broadly speaking, the PV manufacturing environment has been challenging in terms of overall profitability. Since 2010, gross margins have varied between $5 \%$ and $25 \%$, while operating margins have varied between $15 \%$ and $-15 \%$ (Feldman, O'Shaughnessy et al. 2020). In this report, we define minimum sustainable prices (MSPs) as having a gross margin of $15 \%$. MSPs are represented by diamonds in all subsequent figures, and error bars are included to indicate pricing at $5 \%$ and $25 \%$ gross margins.

Assessing the operating margin that a firm needs to sustain or expand its business is complex, being based on the firm's working capital needs, expected returns, stage of growth, and other elements. The actual attainable operating margin depends on the firm's cost structure and the industry's supply and demand conditions. Although not a viable long-term business strategy, some firms might continue to offer prices below cash costs. This strategy is often used by firms trying to increase their sales and market share, but it requires the firms to maintain adequate working capital and continue to push manufacturing costs down.

\subsection{Technology Evolution Framework}

The goal of the TEF is to compare the historical progress and potential trajectory of PV across different absorbers and cell architectures, providing insights into the mechanisms of progress and the pace at which each technology is evolving. Designed with the R\&D community in mind, the 
TEF concept documents the necessary metrics and corresponding potential of each PV technology to gain greater market acceptance.

We use three TEF metrics based on their direct relationship to LCOE: system cost, annual energy output, and service life. These metrics are mapped onto a radar plot as shown in Figure 2. The units for each metric ( $\$ / \mathrm{m}^{2}$ for system cost, $\mathrm{kWh} / \mathrm{m}^{2}$ for annual energy, and years for service life) prevent effects on LCOE from being double counted. The system cost axis is inverted to be consistent with the other metrics: a value farther from the center represents a lower LCOE.

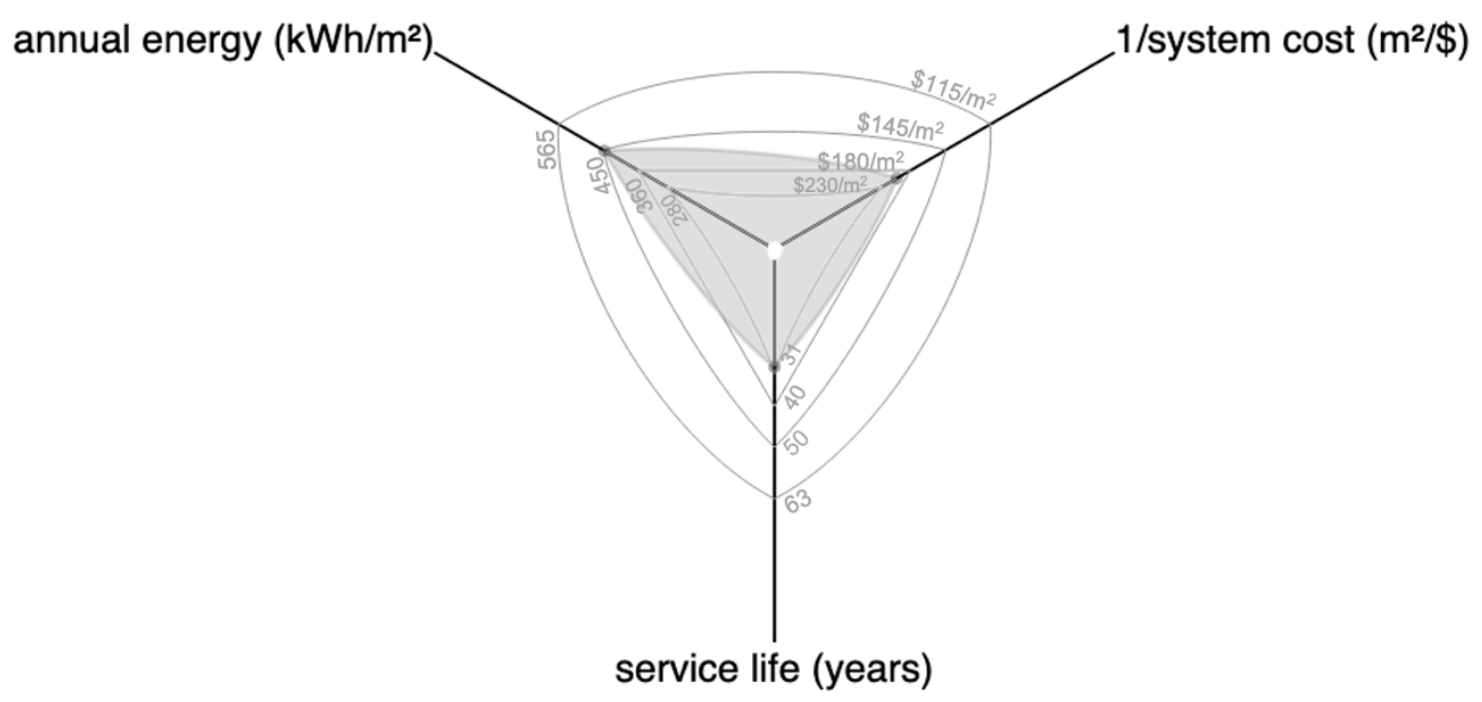

Figure 2. Example of TEF radar plot format

To a first approximation, the coordinates are roughly proportional to 1/LCOE. However, directly joining points on these three axes does not generally produce a shape whose area is proportional to $1 / \mathrm{LCOE}$. To correct this, we add a bulge to increase the shape's area or a pucker to decrease the shape's area. An example data set is shown as gray shading on the figure. The lines connecting the data on the axes are defined by arcs so that movement along an axis creates a proportional change in area. The concentric contours shown in the background of the plot represent equilateral positions on each axis, and each concentric contour proceeding outward represents approximately $10,5,2$, and 1 cents/kWh LCOE, respectively.

System cost and energy yield data are estimated using an online PV-specific LCOE calculator (Silverman, Deceglie et al. 2018) assuming single-axis tracker utility-scale PV systems under Kansas City insolation. The efficiency values used to calculate system cost and energy yield are estimated at an operating temperature of $50^{\circ} \mathrm{C}$ using technology-specific temperature coefficients. Bifacial modules are assumed to have an $8 \%$ relative efficiency advantage over a comparable monofacial architecture. Service life is defined as years until modules are operating below $80 \%$ of rated power, estimated using technology-specific degradation rates.

Data for module price, efficiency, temperature coefficient, and degradation rates are from NREL benchmarks when possible, and through expert consensus otherwise. To illustrate the rate of 
change for each technology, historical performance and projections are reported in 10-year intervals (2010, 2020, and 2030). Values for 2010 are from various sources (U.S. Department of Energy 2012, Woodhouse, Horowitz et al. 2016). Values for 2020 reflect the benchmark results in this report, the most recent system benchmark results (Feldman, Ramasamy et al. Forthcoming), and industry interviews, including the 2020 NREL TEF Workshop (National Renewable Energy Laboratory 2020). The 2030 values are based on industry interviews and literature (ITRPV Working Group 2019). For each technology, the 2030 values are chosen to produce an LCOE of 3 cents/kWh - the 2030 target set by the Solar Energy Technologies Office of the U.S. Department of Energy - while accounting for the known strengths and limitations of the given technology. For the 2030 LCOE projections, we use the online LCOE calculator configured for single-axis tracker utility-scale systems (Silverman, Deceglie et al. 2018). We assume that operation and maintenance costs drop to $\$ 10$ per $\mathrm{kW}_{\mathrm{DC}} /$ year-below the current system benchmark of $\$ 12$ per kW DC/year (Feldman, Ramasamy et al. Forthcoming) — powerscaling balance-of-system costs drop to $\$ 0.25 / \mathrm{W}$, and area-scaling balance-of-system costs drop to $\$ 60 / \mathrm{m}^{2}$. All input values behind the TEF datasets and resulting LCOE values are published in the appendix.

\section{PV Technologies in Mass Production}

This section reviews PV technologies that have global production capacity on the order of gigawatts in 2020: c-Si, CdTe, and CIGS. For each, we provide an overview of their most commonly used manufacturing methods and discuss their fit within the technology assessment criteria described above. We compile 2020 benchmark step-by-step costs into total module manufacturing costs. We conclude each section with roadmaps of future cost projections and each technology's past, present, and projected TEF scores.

\subsection{Crystalline Silicon (c-Si)}

Historically, c-Si has dominated the global PV module market. It accounted for greater than $90 \%$ of PV production in 2014 when total module shipments were about $40 \mathrm{GW}$ (SPV Market Research 2019), and it accounted for around 94\% of PV shipments in 2019 when total module shipments were about 124 GW (SPV Market Research 2020). The market competitiveness of cSi has been sustained by improvements in cell and module efficiencies and by optimization of manufacturing at scales enabling dramatic cost reductions.

The major stages in the supply chain for c-Si PV, including monocrystalline and multicrystalline designs, are depicted in Figure 3. Monocrystalline wafers are sawn from cylindrical ingots grown by the Czochralski (Cz) process. Typical Cz monocrystalline ingots in 2019 were 200-215 mm in diameter and around 3-6 m long, with a mass of 225-800 kg (375 kg median) (ITRPV Working Group 2020). These ingots are made "pseudo-square" - to produce wafers that can attain greater cell packing density on modules - by sawing each ingot along its length after the tops and tails are cropped off, after which the exposed faces are polished and corners are rounded off. The pseudo-square brick is then glued to a glass plate and placed into a wire sawing machine. After wire sawing is complete, the glue still adhering the wafers to the glass backing is dissolved in a chemical bath. Lastly, the wafers are cleaned, inspected for damage, and sorted for shipping to customers. This process results in about 10,000-14,000 wafers per ingot. 


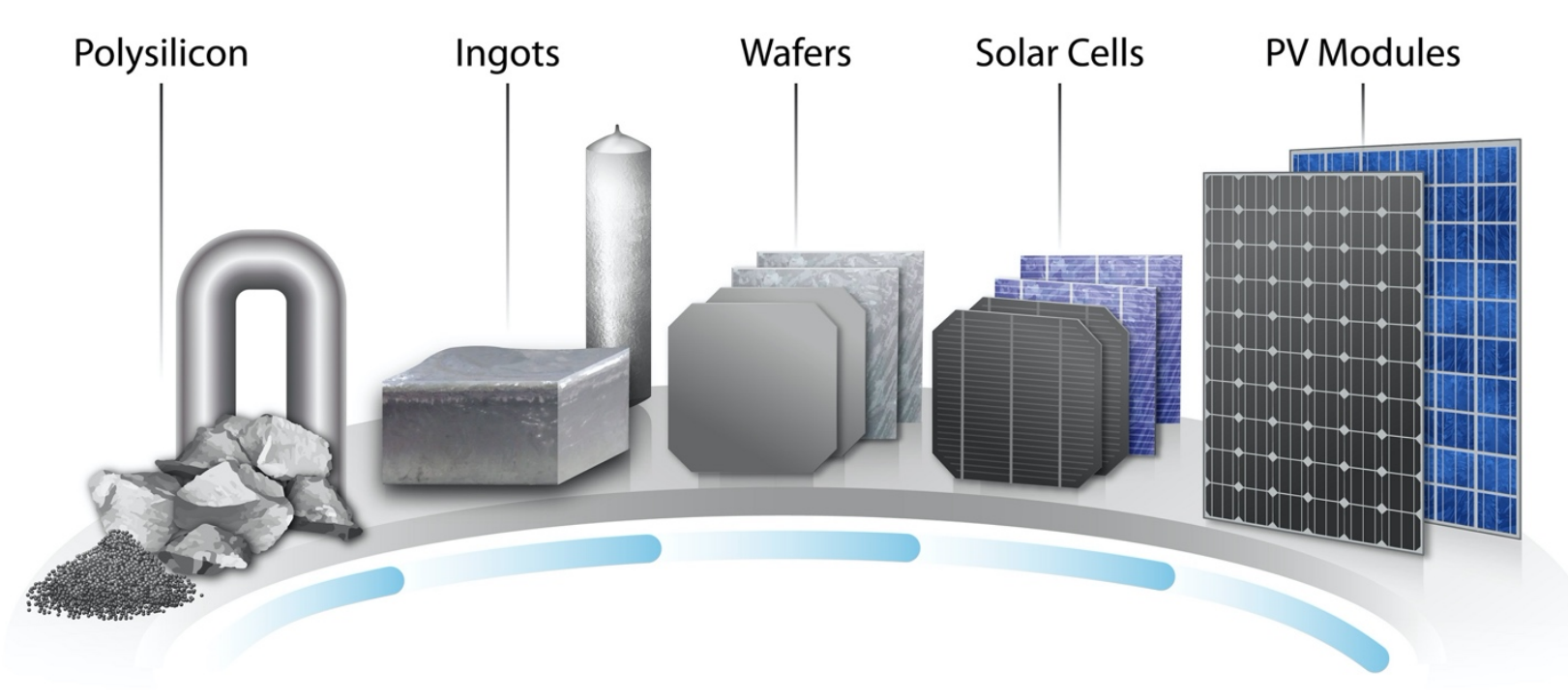

Figure 3. Major steps in the c-Si supply chain (Woodhouse, Smith et al. 2019)

Until recently, the dominant $\mathrm{Cz}$ wafer size was 156.75 x $156.75 \mathrm{~mm}$ flat-to-flat, with a total surface area of $244 \mathrm{~cm}^{2}$, referred to as the "M2 format." However, multiple larger wafer formats have emerged into the mainstream over the past year. Here, we analyze the M4 format, which has a surface area of $258 \mathrm{~cm}^{2}$.

Multicrystalline wafers are sawn from cube-shaped ingots with masses between 850 and 1,200 $\mathrm{kg}$ (ITRPV Working Group 2019). Multicrystalline ingots are formed by melting polysilicon followed by directional solidification. Because multicrystalline ingots assume the shape of the cubic crucible, multicrystalline wafers are naturally full squares. This shape inherently reduces gaps between cells_or "dead areas" - on modules, which previously gave multicrystalline modules an efficiency advantage over monocrystalline modules. However, monocrystalline efficiencies have now greatly surpassed multicrystalline efficiencies, and use of shingling and other cell-interconnection technologies minimizes the dead areas and resistive losses that occur when assembling cells into a final module. In 2019, typical 72-cell multicrystalline modules were rated at 320-350 W, whereas monocrystalline modules with half-cut cells were rated at $430-440 \mathrm{~W}$. These trends may help explain the projected monocrystalline market share growing from $60 \%$ in 2019 to almost $90 \%$ by 2025 (ITRPV Working Group 2019).

Until recently, the full-area Al back surface field (Al-BSF) cell was the dominant design for c-Si (monocrystalline and multicrystalline) PV (Woodhouse, Smith et al. 2019). However, in the past 3 years, the passivated emitter and rear cell (PERC) architecture has become more widely used owing to its $1.0 \%-1.5 \%$ absolute module area efficiency improvement (Woodhouse, Smith et al. 2019). The efficiency gains have been realized via the recent ability of cell manufacturers to implement backside passivation steps in high-throughput production. Other cell architectures that could deliver even higher efficiencies include the interdigitated back contact (IBC) cell, the passivated emitter rear totally diffused (PERT) cell, passivated emitter rear locally diffused (PERL) cell, and silicon heterojunction (SHJ) cell. Cross-sections for these cell types are depicted in Figure 4, including PERC shown with a monofacial contact configuration (bifacial configurations are also used). 


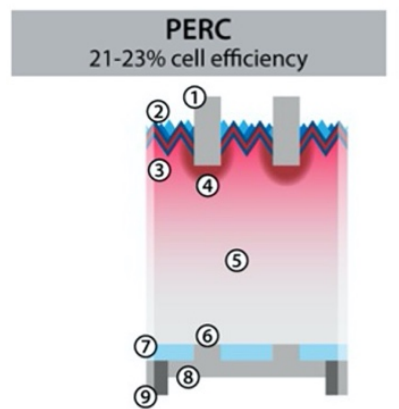

1. Screen-printed Ag

2. $S i N_{X} A R C$ and passivation layer by PECVD

3. $n^{+}$doping and full-area emitter formation by $\mathrm{POCl}_{3}$ diffusion

4. Laser-formed elective emitter*

5. High lifetime $p$-type base wafer

6. Localized $p^{+}$BSF between Si and Al formed by laser opening

7. Backside reflection and passivation layer $\left(\mathrm{SiO}_{x}\right.$ and

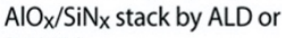
PECVD)

8. Screen-printed full area Al paste

9. Rear Ag pads for cell interconnection

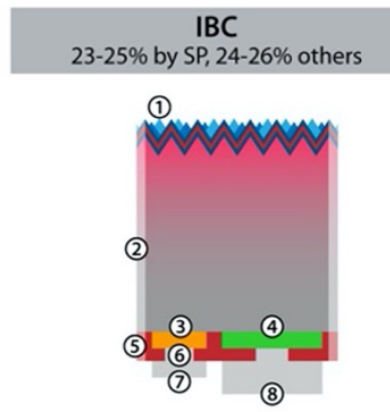

1. SiN $X$ ARC and passivation layer by PECVD

2. High lifetime $n$-type base wafer

3. $\mathrm{n}^{++}$doping and back surface field formation for contact to cell metallization

4. $p^{+}$doping and emitter formation for contact to cell metallization

5. Separation of $n^{++}$BSF and $p^{+}$ emitter by dielectric layer(s)

6. Laser opening of dielectric layers for electroplated contacts or high temperature fire-through of metallization pastes

7. Metal finger $\left(n^{++}\right.$contact)

8. Metal finger ( $p^{+}$contact)

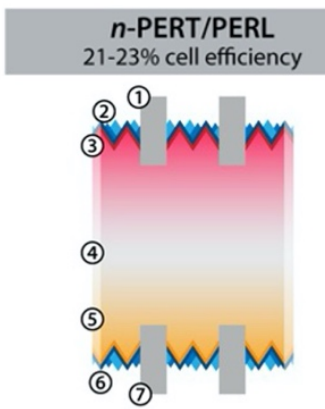

1. Ag and $\mathrm{Al}$ front metallization by screen-printing

2. $\mathrm{SiN}_{\mathrm{X}} \mathrm{ARC}$ and passivation layer by PECVD

3. $p^{+}$doping and full-area emitter formation by ion implantation or $\mathrm{BBr}_{3}$ diffusion

4. High lifetime $n$-type base wafer

5. Full-area $n^{+}$doping by $\mathrm{POCl}_{3}$ diffusion

6. Backside $\mathrm{SiN}_{\mathrm{X}}$ passivation layer by PECVD

7. Ag rear metallization (sometimes full-area) by screen-printing or PVD
SHJ 23-25\% cell efficiency

(2) (1)

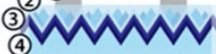

(5)

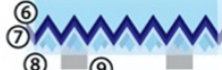

1. Frontside fingers (busbars optional) compromised of low-temperature screenprinted Ag pastes or electroplated $\mathrm{Ni} / \mathrm{Cu} / \mathrm{Sn} / \mathrm{Ag}$

2. TCO by PVD (typically ITO for high optical transmission and low sheet resistance)

3. $p^{+}$doping and full-area emitter formation by PECVD of a-Si:H

4. Intrinsically doped a-Si:H by PECVD

5. High lifetime n-type base wafer

6. Intrinsically doped a-Si:H by PECVD

7. $n^{+}$doping and full-area BSF formation by PECVD of a-Si:H

8. TCO by PVD (typically ITO for high optical transmission and low sheet resistance)

9. Backside fingers (busbars optional) comprised of low-temperature screenprinted Ag pastes or electroplated $\mathrm{Ni} / \mathrm{Cu} / \mathrm{Sn} / \mathrm{Ag}$

Figure 4. c-Si device designs: p-type (PERC) and n-type (IBC, PERT/PERL, and SHJ)

Table 1 reports the approximate global production scale for each of these c-Si PV technologies in 2019 as well as bifaciality factors and power temperature coefficients determined via discussion with experts at the 2020 NREL TEF Workshop (National Renewable Energy Laboratory 2020). Both Al-BSF and PERC technologies have increased in manufacturing scale since 2010; however, there are predictions of flat to declining market share by 2025 for Al-BSF and PERC multicrystalline Si as well as Al-BSF monocrystalline Si. Al-BSF cells are predicted to have less than 10\% market share by 2025 (ITRPV Working Group 2019), which would correspond to less than $20 \mathrm{GW}$ of total (monocrystalline and multicrystalline) Al-BSF production. The use of passivated contacts for p-type monocrystalline $\mathrm{Si}$ is predicted to grow from $0 \%$ in 2019 to $10 \%$ by 2025 , representing a rapid market uptake of $20 \mathrm{GW}$ within 5 years. The PERC market share grew from virtually $0 \%$ in 2010 to about $40 \%$ by 2018 , and it is expected to surpass $50 \%$ by 2020 (ITRPV Working Group 2012, ITRPV Working Group 2019). Bifacial cell types are predicted to grow from an estimated $15 \%$ market share in $2019(15-20 \mathrm{GW})$ to $50 \%$ by 2025 (100 GW) (ITRPV Working Group 2019); this total includes PERC, SHJ, and PERT/PERL architectures. 
Table 1. c-Si PV Metrics Relevant to Production Scale and Energy Yield

\begin{tabular}{lccccc}
\hline & Al-BSF & PERC & PERT/PERL & SHJ & Back Contact \\
\hline $\begin{array}{l}\text { Production } \\
\text { scale in 2019 }\end{array}$ & $\begin{array}{l}20 \mathrm{GW} \text { (multi-) } \\
\text { 30 GW (mono-) }\end{array}$ & $\begin{array}{l}20 \mathrm{GW} \text { (multi-) } \\
30 \mathrm{GW} \text { (mono-) }\end{array}$ & $5 \mathrm{GW}$ & $5 \mathrm{GW}$ & $\begin{array}{c}500 \mathrm{MW} \\
\text { (IBC with mono-) } \\
\text { 2 GW } \\
\text { (MWT with multi-) }\end{array}$ \\
\hline $\begin{array}{l}\text { Bifaciality } \\
\text { factor }\end{array}$ & N/A & $0.65-0.80$ & $0.85-0.90$ & $0.80-0.95$ & $0.40-0.50$ \\
\hline $\begin{array}{l}\text { Power } \\
\text { temperature } \\
\text { coefficient (\% } \\
\text { per }{ }^{\circ} \mathrm{C} \text { ) }\end{array}$ & -0.35 to -0.40 & -0.25 to -0.40 & $\begin{array}{c}-0.40 \text { to } \\
-0.45\end{array}$ & $\begin{array}{c}-0.25 \text { to } \\
-0.30\end{array}$ & -0.25 to \\
\hline $\begin{array}{l}\text { PERT/PERL and SHJ are believed to be relevant for monocrystalline only. Back contact includes IBC for } \\
\text { monocrystalline and metal wrap through (MWT) for multicrystalline. The bifaciality factor is measured via a controlled } \\
\text { indoor experiment to determine the amount of electricity generated from the cell backside versus frontside with the } \\
\text { same illumination profile and intensity and at the same temperature. }\end{array}$
\end{tabular}

Together, all n-type cell architectures constituted roughly $11 \mathrm{GW}$ of cell production $(10 \%$ market share) in 2019 (ITRPV Working Group 2019). Historically, the technical skill and high-volume manufacturing capabilities for $\mathrm{n}$-type options were limited to a few producers who were constrained by the availability of n-type wafers. More recently, however, n-type wafers have become more available at prices within $5 \%-10 \%$ of prices for the monocrystalline p-type wafers used for PERC. All n-type cell architectures shown have intellectual property that is fully licensable. Except for IBC, all have multiple vendors offering turnkey manufacturing solutions, at scales of $50 \mathrm{MW}$ up to multiple gigawatts.

More specifically, SHJ is predicted to grow from 5\% market share in 2019 (5.5 GW) to $13 \%$ (26 GW) by 2025, whereas the market share for back contact technologies including IBC and MWT may grow from 3\% in 2019 (3.3 GW) to 8\% by 2025 (16 GW) (ITRPV Working Group 2019). The market growth for back contact technologies may be driven primarily by the higher efficiencies and smaller temperature coefficients, although growth may be hindered by higher manufacturing costs due to increased process complexity. IBC cells can use screen printing to reduce process complexity, but the power conversion efficiency of an all-screen-printed IBC cell does not clearly outperform passivated contacts on p-type monocrystalline or SHJ cells. However, back contact technologies may retain demand in the residential market for aesthetic reasons.

The efficiency progress of c-Si cells over time is shown in Figure 5. For monocrystalline $\mathrm{Si}$, the two most recent 1-sun cell records are attributed to Fraunhofer Institute for Solar Energy Systems (ISE) and Institute for Solar Energy Research in Hamelin (ISFH) (Green, Dunlop et al. 2019). Notable features of high-performing monocrystalline modules include half-cut cells, busbarless cell metallization and interconnection, and glass-glass or glass-transparent backsheet bifacial modules. Not all of the methods used to fabricate champion monocrystalline cells and modules have been demonstrated in large-scale commercial production.

For multicrystalline $\mathrm{Si}$, the two most recent cell records are attributed to ISE. Trina Solar has the most recent champion multicrystalline module. Multicrystalline MWT technology, which has recently become more widely available, is approaching $20 \%$ module area efficiency and may have reached greater than $2 \mathrm{GW}$ of production in 2019 (Osborne 2019). Not all of the methods 
used to fabricate champion multicrystalline cells and modules have been demonstrated in largescale commercial production.

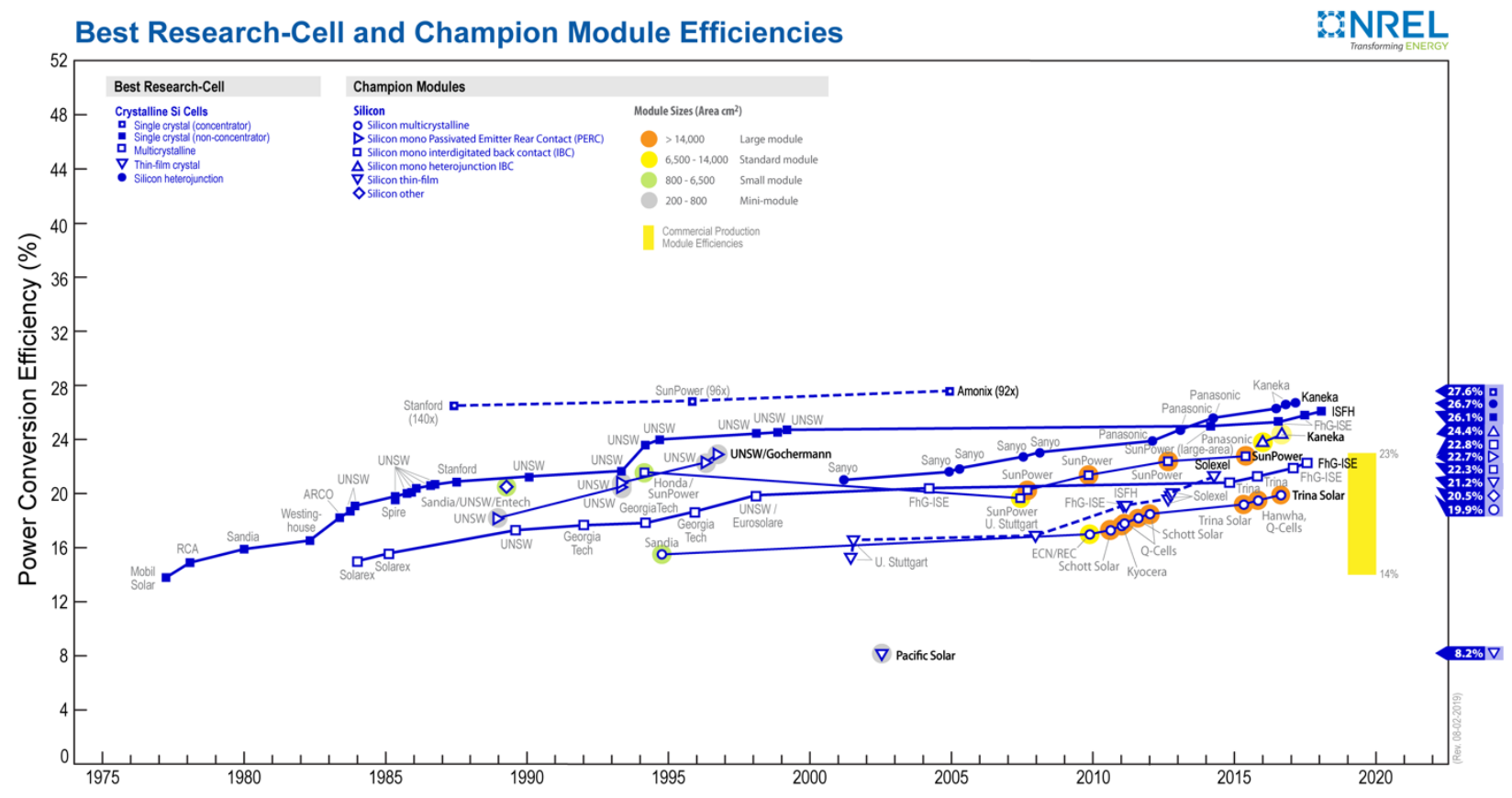

Figure 5. c-Si cell and module efficiency progress

\subsubsection{Process Flows and Costs by Step}

This section focuses on the most recent cost details for monocrystalline PERC owing to that technology's current market share and projected growth. The typical process flows for monofacial PERC cell and module production are shown in Figure 6 and Figure 7. 


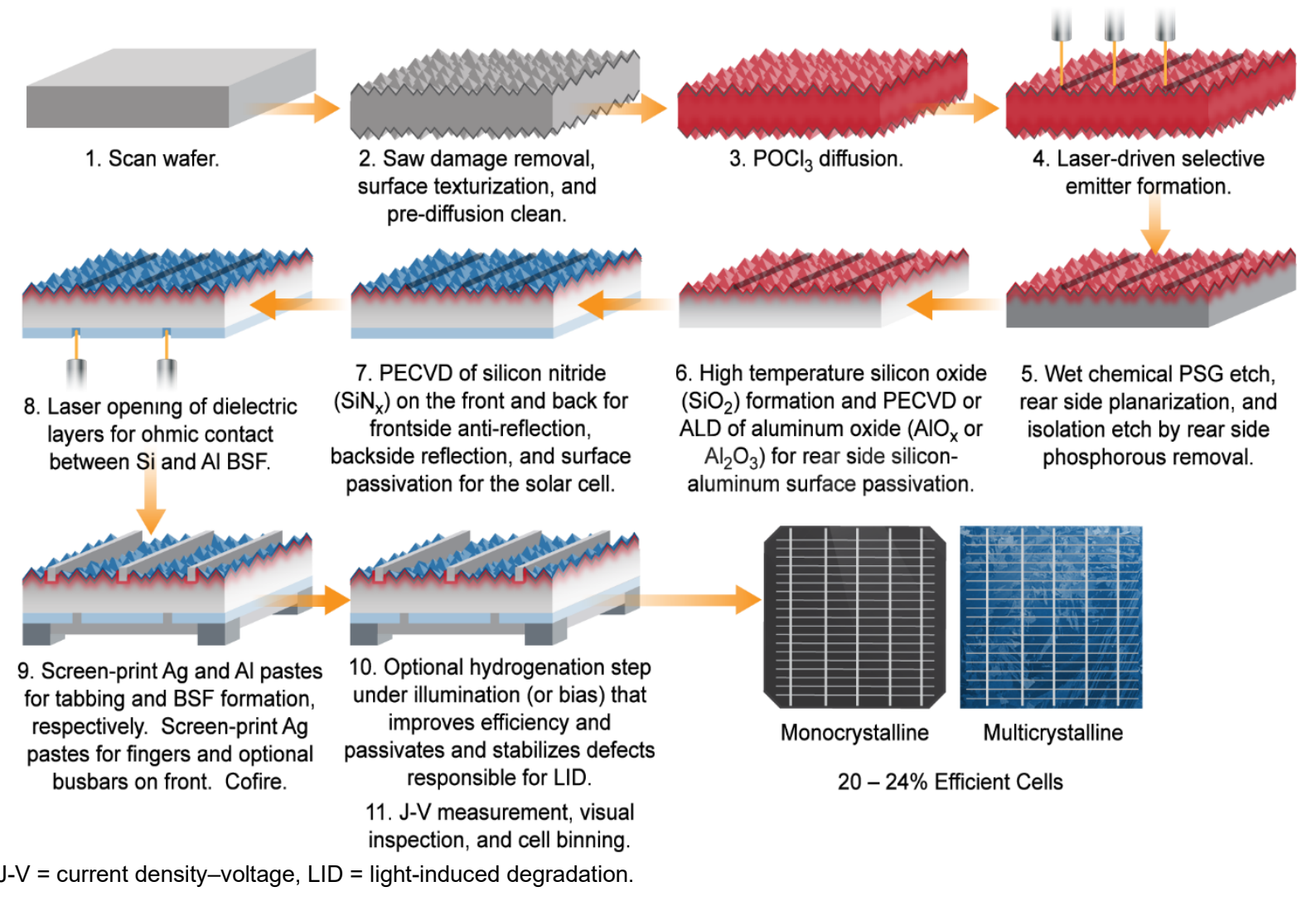

Figure 6. Typical process flow for manufacturing monocrystalline (left) and multicrystalline (right) PERC cells in 2020

The PERC cell conversion process begins by assessing the quality of an incoming wafer, then wet chemical treatments of a p-type wafer and high-temperature diffusion of $\mathrm{POCl}_{3}$ to form a $\mathrm{p}$-n electrical junction in the cell. A sophisticated process that has recently surfaced in high-volume production is the use of laser-patterned selective emitters (Step 4), creating a grid of higher dopant density directly beneath the cell metallization, which imparts a small efficiency advantage.

The efficiency advantage that PERC achieves over the Al-BSF cell architecture is mostly due to an additional passivation layer stack on the cell backside. This is typically achieved by plasmaenhanced chemical vapor deposition (PECVD) or atomic layer deposition (ALD) of alumina on the wafer surface following the high-temperature $\mathrm{POCl}_{3}$ diffusion and wet chemical phosphosilicate glass (PSG) etch. PECVD of silicon nitride $\left(\mathrm{SiN}_{\mathrm{x}}\right)$ imparts an additional passivation material on the back and can be done simultaneously on the front for surface passivation and anti-reflection properties on that side. The use of high-throughput and precise lasers has become critical throughout the PERC process, including opening of the backside passivation stack for direct contact between the parent Si wafer and the Al metal that forms the back-surface field in the cell (Step 8). The rear metal can be applied over the full area for use in monofacial modules, or selectively for bifacial modules.

The process of module assembly shown in Figure 7 starts by connecting cells electrically into strings, which are then laid in an array and electrically connected via metallic ribbons. The array 
of parallel strings is mounted onto an encapsulant layer, which sits atop a glass sheet or polymer backsheet. An additional sheet of encapsulant plus front glass is stacked onto the string array, and the entire stack is laminated by melting the encapsulant. The ribbons are threaded through a gap in the polymer backsheet or back glass and into a junction box with diodes to protect against cell mismatch. Generally, the last step is to fit an anodized extruded Al frame around the module's edges, though this can be omitted in some designs.

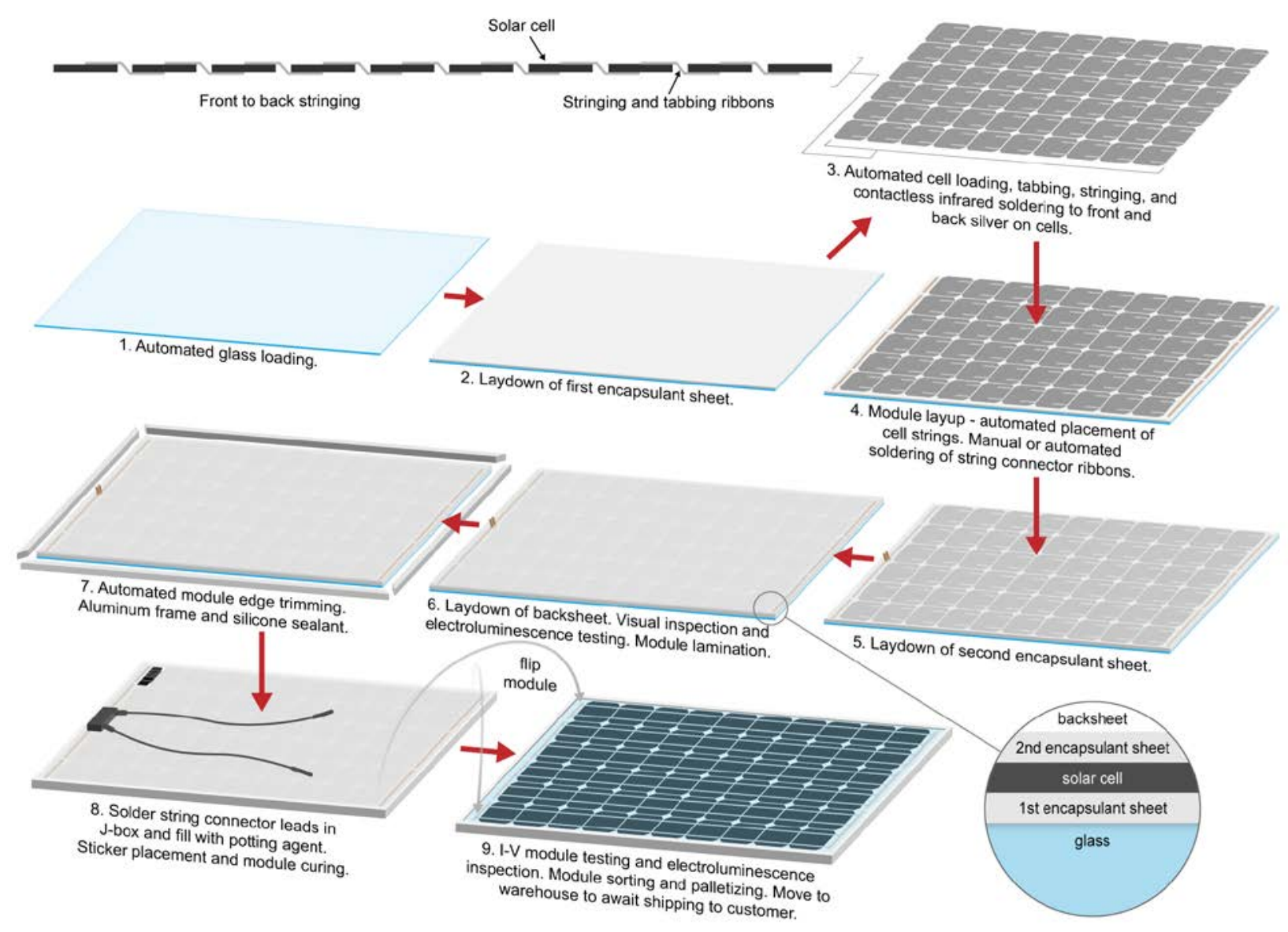

$\mathrm{I}-\mathrm{V}=$ current-voltage, $\mathrm{j}$-box $=$ junction box.

\section{Figure 7. Process flow for manufacturing standard PERC modules}

Table 2 summarizes the inputs used to model PERC wafer, cell, and module production costs. For more detailed information related to these processes, and 2018 benchmark manufacturing costs, an in-depth report including polysilicon and wafer production process flows is available (Woodhouse, Smith et al. 2019).

Figure 8 and Figure 9 show a step-by-step cost breakdown for cells and modules, respectively. Because several steps are now calculated to be below $\$ 0.01 / \mathrm{W}$ in cost - and because the total cost for cell conversion has decreased to less than $\$ 0.05 / \mathrm{W}$ - the precision required to execute cost models has become increasingly stringent. 
Table 2. Overview of Inputs Used in NREL's PERC Cost Models

\begin{tabular}{|c|c|}
\hline \multicolumn{2}{|c|}{ Variable COGS Inputs } \\
\hline \multirow[t]{2}{*}{$\begin{array}{l}\text { Principal } \\
\text { input } \\
\text { materials }\end{array}$} & $\begin{array}{l}\text { Cells: Si wafers. Water-based solutions for PSG removal and surface texturization } \\
\left(\mathrm{KOH}, \mathrm{HF}, \mathrm{HNO}_{3}, \mathrm{HCl}\right) . \mathrm{POCl}_{3}\left(\text { or } \mathrm{BBr}_{3}\right) \text { for doping by thermal diffusion. } \mathrm{NH}_{3} \text { and } \\
\mathrm{SiH}_{4} \text { precursors for } \mathrm{SiN}_{\mathrm{x}}: \mathrm{H}_{\text {by }} \mathrm{PECVD} \text {. Trimethyl } \mathrm{Al}(\mathrm{TMAl}) \text { for } \mathrm{PERC} \text { passivation } \\
\text { layers. Al and Ag metallization screens and pastes for printing. }\end{array}$ \\
\hline & $\begin{array}{l}\text { Modules: Cell stringing and tabbing ribbons, front glass, backsheet, } 2 \text { sheets of } \\
\text { polyolefin (POE) or ethylene-vinyl acetate (EVA) encapsulant, Al frame and edge } \\
\text { sealant, junction box, potting agent and tape for the junction box, and coded sticker } \\
\text { label for the module. }\end{array}$ \\
\hline \multirow[t]{2}{*}{ Labor } & $\begin{array}{l}\text { Cells: } 0.15-0.45 \text { direct employees per MW of annual cell production depending on } \\
\text { cell architecture. }\end{array}$ \\
\hline & $\begin{array}{l}\text { Modules: } 0.5-0.7 \text { direct employees per MW of annual module production, } \\
\text { depending on level of automation. }\end{array}$ \\
\hline \multirow[t]{2}{*}{ Electricity } & $\begin{array}{l}\text { Cell fabrication: } 0.4-0.5 \mathrm{kWh} \text { per SHJ cell, } 0.3-0.5 \mathrm{kWh} \text { per cell for all other } \\
\text { architectures; excludes polysilicon, ingot, and wafer production stages. }\end{array}$ \\
\hline & Modules: $15 \mathrm{kWh}$ per 72 -cell module. \\
\hline Maintenance & $\begin{array}{l}\text { Cells: Annual cost corresponding to } 3 \% \text { of the original investment in equipment. } \\
\text { Modules: Annual cost corresponding to } 4 \% \text { of the original investment in equipment. }\end{array}$ \\
\hline \multicolumn{2}{|c|}{ Fixed COGS Inputs } \\
\hline \multirow{2}{*}{$\begin{array}{l}\text { Equipment } \\
\text { CapEx and } \\
\text { depreciation }\end{array}$} & $\begin{array}{l}\text { Cells: Equipment CapEx of } \$ 0.10-\$ 0.18 / \mathrm{W} \text { for } \mathrm{SHJ} \text { cell lines, } \$ 0.03-\$ 0.10 / \mathrm{W} \text { for } \\
\text { other cell lines. 5-year depreciation (straight line). }\end{array}$ \\
\hline & $\begin{array}{l}\text { Modules: Equipment CapEx of } \$ 0.03-\$ 0.05 / \mathrm{W} \text { for PERC and standard modules. 5- } \\
\text { year depreciation (straight line). }\end{array}$ \\
\hline \multirow{2}{*}{$\begin{array}{l}\text { Facilities } \\
\text { CapEx and } \\
\text { depreciation }\end{array}$} & $\begin{array}{l}\text { Cells: } \$ 0.02-\$ 0.03 / \mathrm{W} \text { total for new facility and building CapEx. 20-year depreciation } \\
\text { (straight line). }\end{array}$ \\
\hline & $\begin{array}{l}\text { Modules: } \$ 0.02-\$ 0.03 / \mathrm{W} \text { total facility and building CapEx. 20-year depreciation } \\
\text { (straight line). }\end{array}$ \\
\hline \multicolumn{2}{|c|}{ Remaining Fixed Operating Expenses } \\
\hline R\&D & $\begin{array}{l}3 \% \text { of value-added revenues (for cells, total revenues minus wafer costs; for } \\
\text { modules, total revenues minus cell costs). }\end{array}$ \\
\hline SG\&A & $\begin{array}{l}9 \% \text { of value-added revenues (for cells, total revenues minus wafer costs; for } \\
\text { modules, total revenues minus cell costs). }\end{array}$ \\
\hline
\end{tabular}

Materials costs dominate total cell conversion costs, calculated by multiplying the unit consumption per cell by the cost per unit. For example, metallization (screen-printing of $\mathrm{Al}$ and Ag pastes), as shown in Figure 8, constitutes 21\% of the total cost - the single largest direct cellconversion cost. The industry-standard material requirements for this step using a five-busbar design are about 70-100 $\mathrm{mg}$ of Ag paste for the front of the cell, 20-50 mg of Ag paste for the back of the cell, and 0.9-1.1 g of Al paste for the back of the cell. However, only $25 \mathrm{mg}$ of Ag paste and $0.3 \mathrm{~g}$ of $\mathrm{Al}$ paste are needed for the rear contact when manufacturing bifacial PERC architectures. 


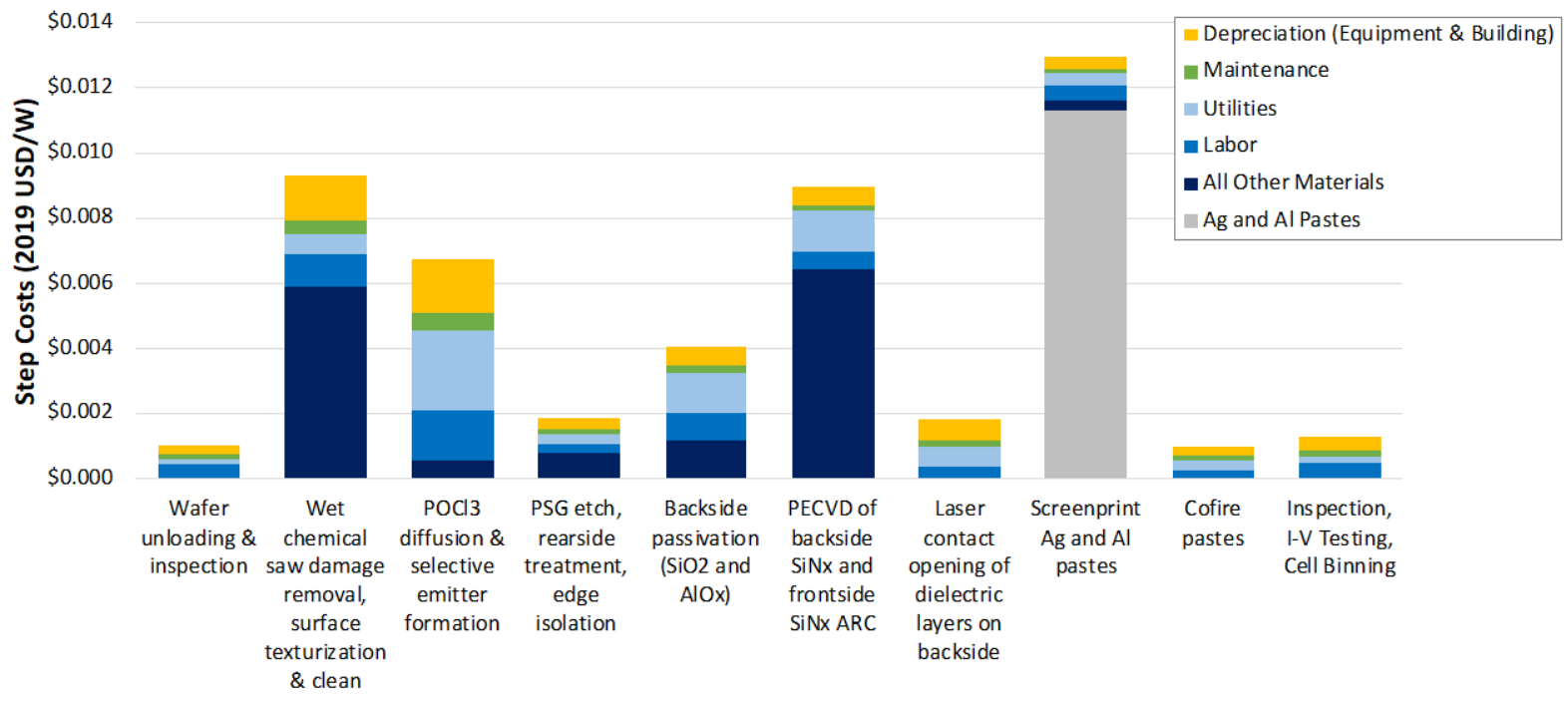

Figure 8. Step-by-step costs for monocrystalline PERC cell production in urban China, 2020

Assumptions include a 2-GW greenfield production facility in urban China for $258-\mathrm{cm}^{2}$ cells on M4 format $\mathrm{p}$-type $\mathrm{Cz}$ wafers, at $22 \%$ cell efficiency. ARC = antireflection coating, USD = U.S. dollars.

The costs in Figure 8 assume $75 \mathrm{mg}$ of Ag paste per cell for the front contact as well as $30 \mathrm{mg}$ of $\mathrm{Ag}$ paste and $0.9 \mathrm{~g}$ of Al paste for the rear contact, and they are based on Ag spot pricing of $\$ 560 / \mathrm{kg}$ from the first half of 2020 (LME (London Metal Exchange) 2020). Based on the makeup of these pastes (including additives), total metallization paste materials costs are calculated as $\$ 0.011 \pm \$ 0.002 / \mathrm{W}$, with $62 \%$ due to frontside $\mathrm{Ag}, 18 \%$ to backside $\mathrm{Ag}$, and $20 \%$ to backside Al.

We assume $0.35 \mathrm{kWh}$ of electricity consumed per cell and 0.45 direct labor full-time employees per MW (\$10,000 per year for line workers and \$15,000 per year for engineers; salaries include benefits). Throughput is assumed to be 6,000 wafers per hour (wph), with the exception of $\mathrm{POCl}_{3}$ diffusion steps at 3,000 wph. The total cost for monocrystalline PERC cell conversion (not including the cost of wafers) comes to $\$ 0.049 / \mathrm{W}$.

Figure 9 provides the results of our cost model for each monocrystalline PERC module assembly step, based on an urban China manufacturing facility that produces more than $1 \mathrm{GW}$ per year. Totaling the costs in this figure results in about $\$ 0.13 / \mathrm{W}$. More than $80 \%$ of the costs are attributed to materials. The next largest contributors are equipment and utilities, mainly occurring during the inspection, electroluminescence, and lamination step. 


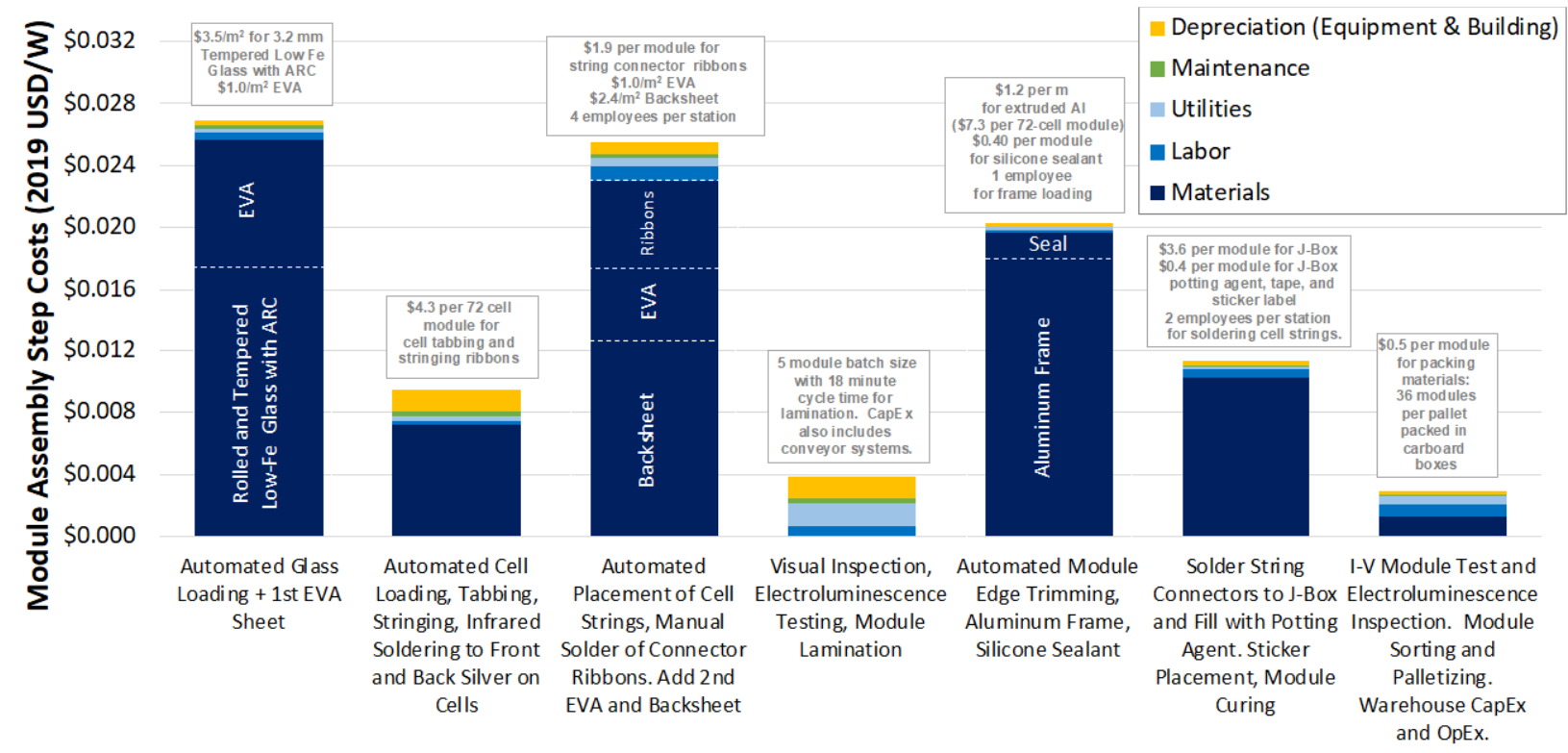

Figure 9. Step-by-step costs for monocrystalline PERC module assembly in urban China, 2020

Assumptions include 400-W modules with 72 half-cut mono-PERC cells (258- $\mathrm{cm}^{2}$ cells, M4 format) at a facility in urban China producing more than $1.0 \mathrm{GW}$ per year. OpEx = operating expenses.

\subsubsection{Benchmark Costs and Technology Roadmap}

Cell cost benchmarks are shown in Figure 10. These benchmarks—as well as the subsequent module benchmarks - assume a gross margin of $15 \%$; error bars show gross margins of $25 \%$ (high MSP) and 5\% (low MSP). PERC cells are the lowest-cost option, followed closely by PERT/PERL. Although performance is reported for frontside power ratings only, bifacial PERC still shows a slight cost advantage due to reduced metallization use compared with full-area rear metallization. Conversely, IBC costs are high owing to higher metallization use. Finally, SHJ costs are higher than most because of costs associated with equipment. 


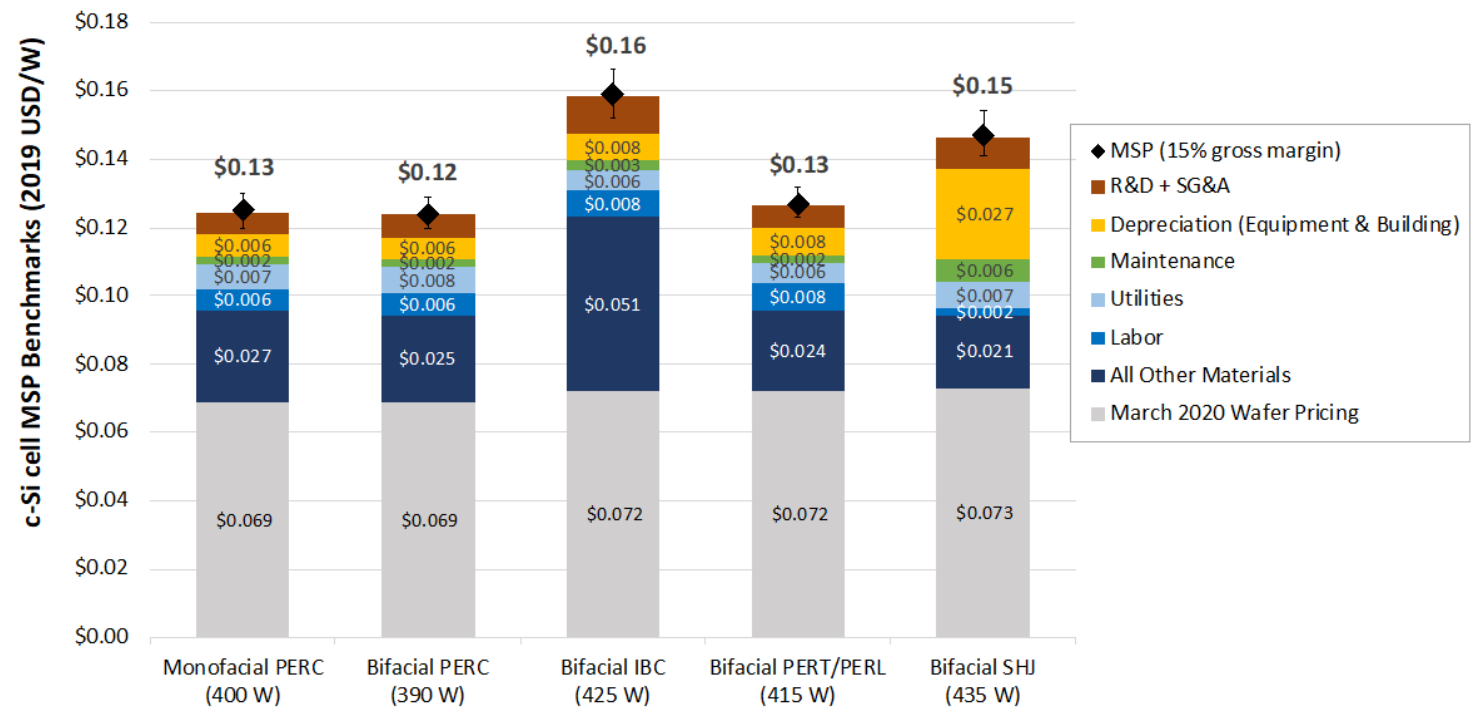

Figure 10. Cell benchmark MSPs by c-Si technology

This analysis assumes 2-GW facilities in urban China, not including tariffs. A $10 \%$ price premium is applied for $n$-type wafers.

Figure 11 shows our cost model summary for p-type $\mathrm{Cz}$ wafer production, PERC cell conversion, and half-cut module assembly. The totals assume all operations are located in urban China at production volumes greater than $1 \mathrm{GW}$ per year. The total estimated CapEx investment for $1 \mathrm{GW}$ of all-new greenfield wafer, cell, and module capacity would be about $\$ 150-\$ 250$ million $(\$ 0.15-\$ 0.25 / \mathrm{W})$. This investment is allocated over linear depreciation schedules that vary from 5 to 10 years (depending on the specific piece of equipment) and 20 years for all facilities. Materials costs alone are higher than all other variable costs plus all fixed costs because of the dual benefits in reducing CapEx while improving automation efficiency and throughput. 


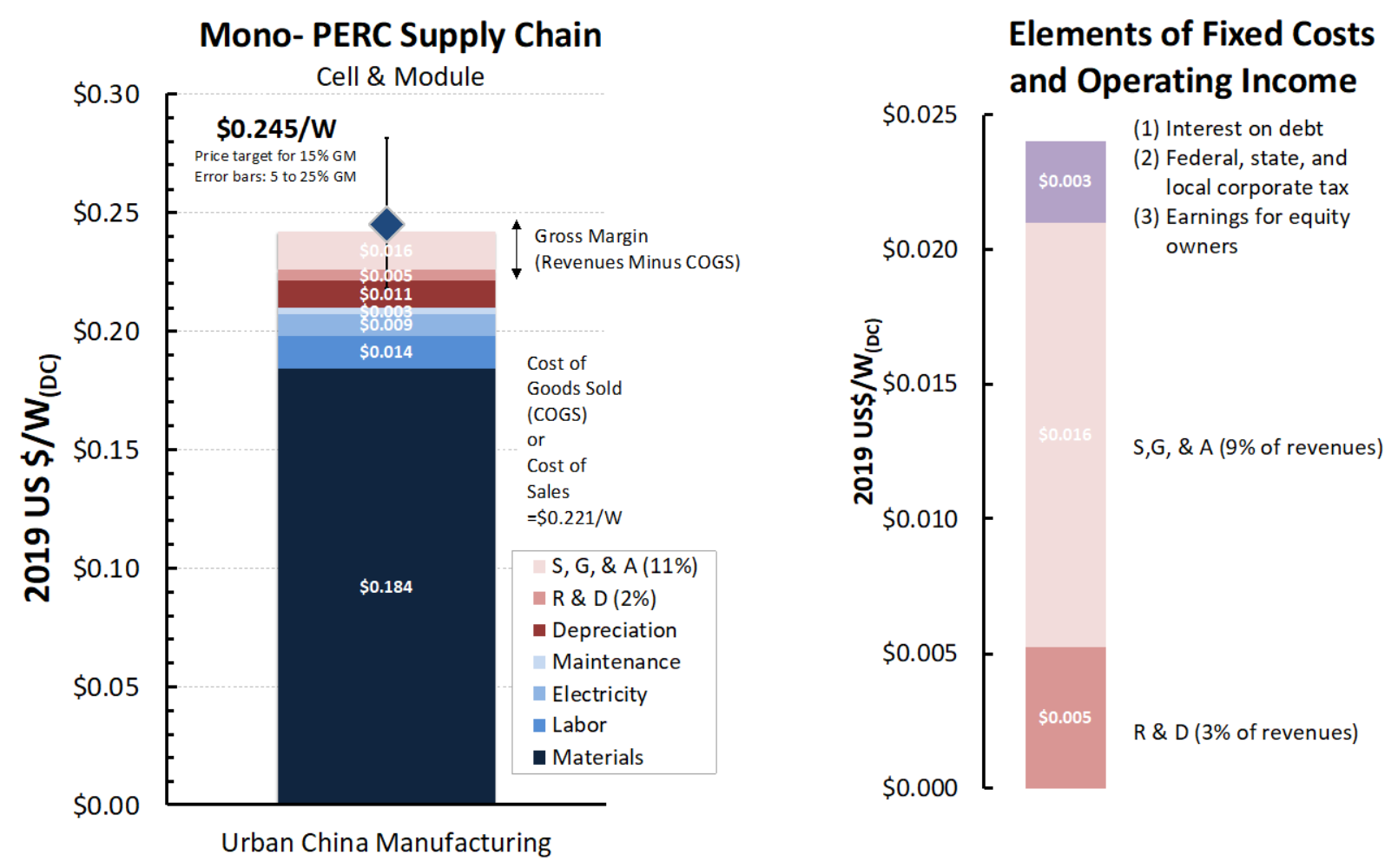

Figure 11. Fixed and variable costs for monocrystalline p-type wafer production, PERC cell conversion, and half-cut module assembly in Urban China

Assumptions include 400-W modules with 72 half-cut mono-PERC cells (M4-format $\left(258 \mathrm{~cm}^{2}\right)$ ) at a facility in urban China producing more than $1.0 \mathrm{GW}$ per year. EBIT = earnings before interest and taxes, GM = gross margin.

Figure 12 compares modeled current cost and price estimates for modules made with monofacial PERC, bifacial PERC, monofacial IBC, bifacial PERT/PERL, and bifacial SHJ cells. These results incorporate some of the unique encapsulant, backsheet, cell interconnection, and tabbing and stringing considerations for each technology. For example, a second sheet of glass is substituted for the white backsheet in bifacial modules so more light can enter the cell backside; the encapsulant is also switched from EVA to POE.

Modules made with monofacial PERC cells represent the lowest-cost option, followed closely by modules made with bifacial PERT/PERL cells. The cost advantage of bifacial PERC cells does not carry over as a module cost advantage because of the second sheet of glass needed for a bifacial module. Transparent backsheets are an alternative to a second sheet of glass for bifacial modules; however, owing to their limited and proprietary manufacture, these are not modeled in the current report. The relative price differences among the different PV technologies are less pronounced for module MSPs than for cell MSPs, because the higher-efficiency technologies require less module material per watt. 


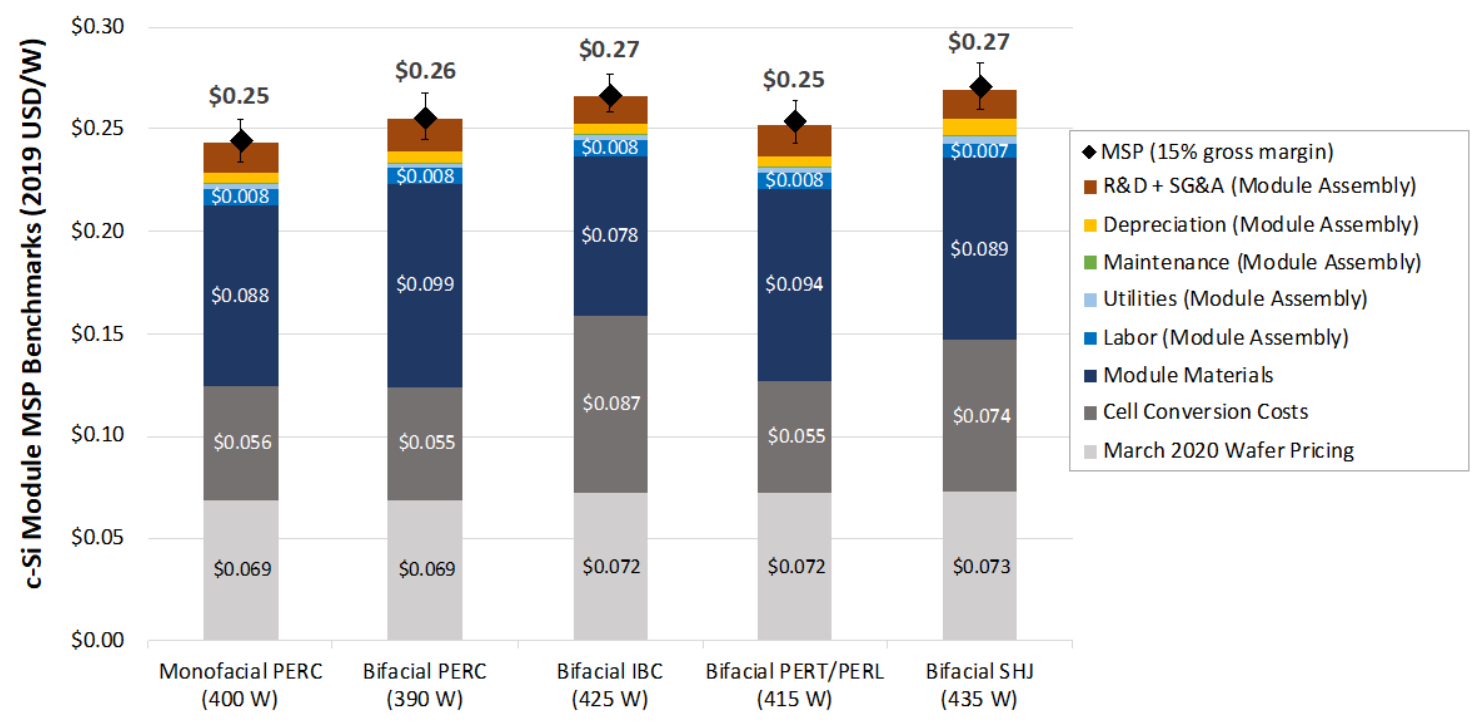

Figure 12. C-Si PV module MSP benchmarks by cell technology, 2020

Assumptions include manufacturing of 72-cell modules in urban China, not including tariffs. All monofacial modules have a glass-backsheet configuration; all bifacial modules assume a glass-glass configuration. Module power is reported for frontside standard test condition ratings only. A $10 \%$ price premium is applied for n-type wafers.

Figure 13 summarizes projected module price estimates. Going forward, the potential additional drop in c-Si module MSPs by 2025 is projected at $25 \%$, with potential for further reductions in the long term. The 2025 projection assumes larger $\mathrm{Cz}$ ingot sizes, thinner wafers (including reduced kerf losses), reduced Ag paste use, higher throughputs, and an increase to 23\% module efficiency. Specifically, this includes increasing ingot mass from $375 \mathrm{~kg}$ to $450 \mathrm{~kg}$, thinning wafers to $160 \mu \mathrm{m}$ thick (from $180 \mu \mathrm{m}$ ) with $60 \mathrm{~mm}$ kerf loss (from $70 \mathrm{~mm}$ ), and moving to an M6 wafer format based on projections (ITRPV Working Group 2020). Furthermore, Ag use is assumed to drop to $50 \mathrm{mg} / \mathrm{cell}$, cell throughput is expected to double, and module throughput is assumed to increase by $30 \%$. The long-term projection assumes average module efficiency increases to $26 \%$ due to widespread adoption of high-efficiency n-type modules. Reduced costs via alternative metallization methods and materials may be possible but are not explicitly modeled in this report. Additional price declines could be achieved through economies of scale, but they are not explicitly modeled in this roadmap. 


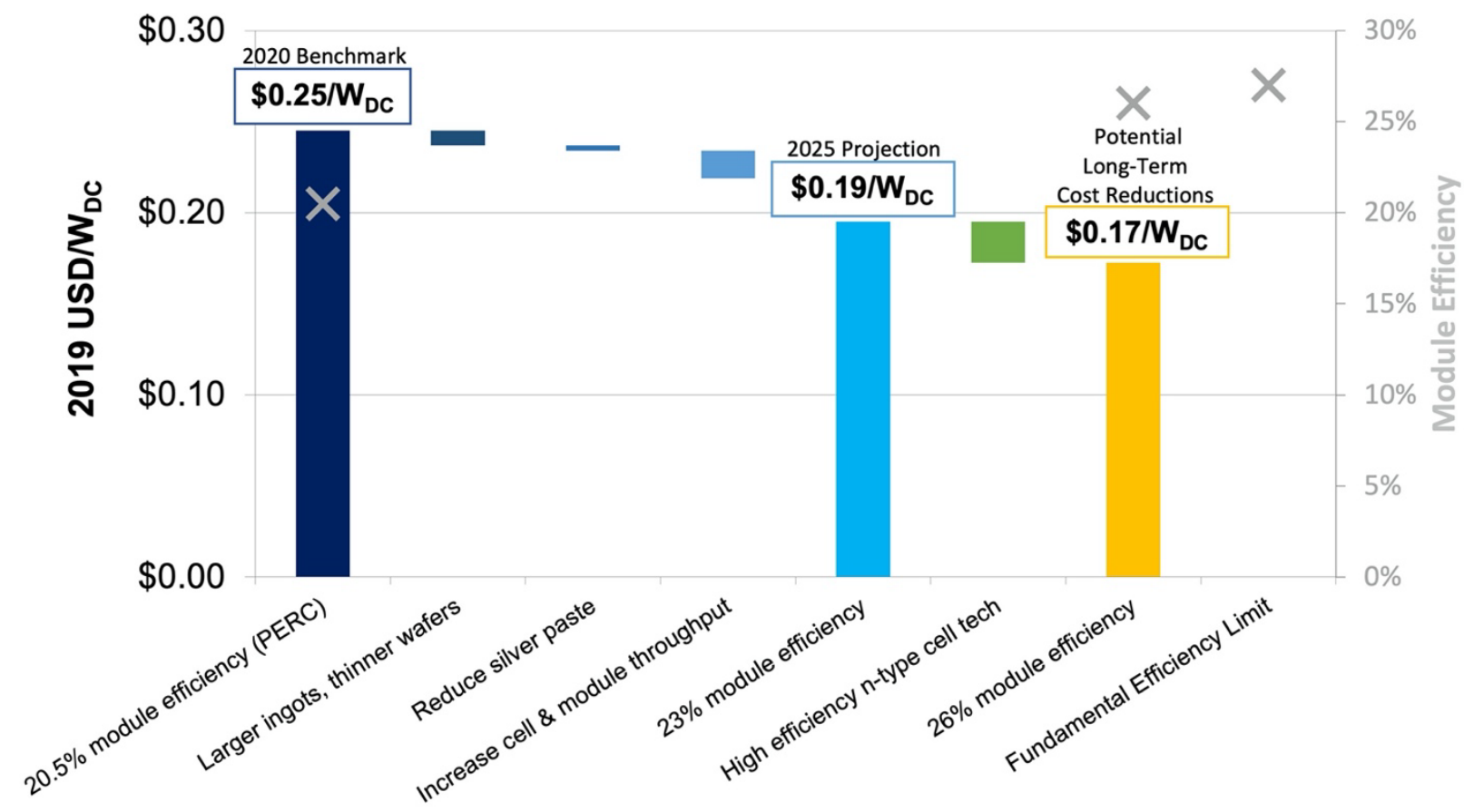

Figure 13. Technology roadmap with projected MSPs for monocrystalline Si modules, assuming $15 \%$ gross margin

The TEF plots for c-Si PV systems are shown in Figure 14. Historical cost modeling results from NREL (Goodrich, James et al. 2011, Goodrich, Hacke et al. 2013) and other literature (Mishima, Taguchi et al. 2011, Wolf, Descoeudres et al. 2012, Tous, Aleman et al. 2015) serve as a primary reference point for the 2010 cost and energy data, while 2020 and 2030 data reflect the cost model results from our current work. These data, as well as other metrics such as power temperature coefficients and degradation rates over time, were determined via discussion with experts at the 2020 NREL TEF Workshop (National Renewable Energy Laboratory 2020). The distinctions between different $\mathrm{c}-\mathrm{Si}$ architectures are slight, because the inherent material properties are constant between technologies. However, the higher energy yield for bifacial formats (assumed $8 \%$ relative to monofacial format) as well as higher-efficiency architectures show these technologies do not require as much progress along the cost axis to achieve the LCOE target of 3 cents $/ \mathrm{kWh}$ by 2030 . 
mono PERC

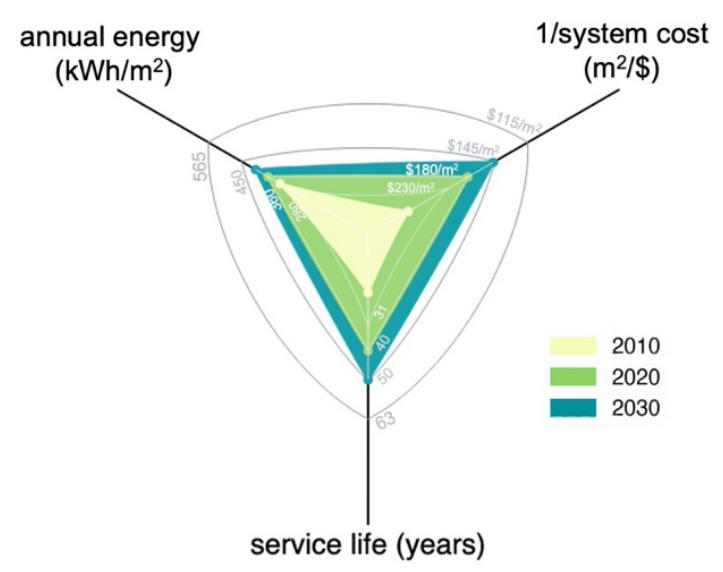

si-IBC

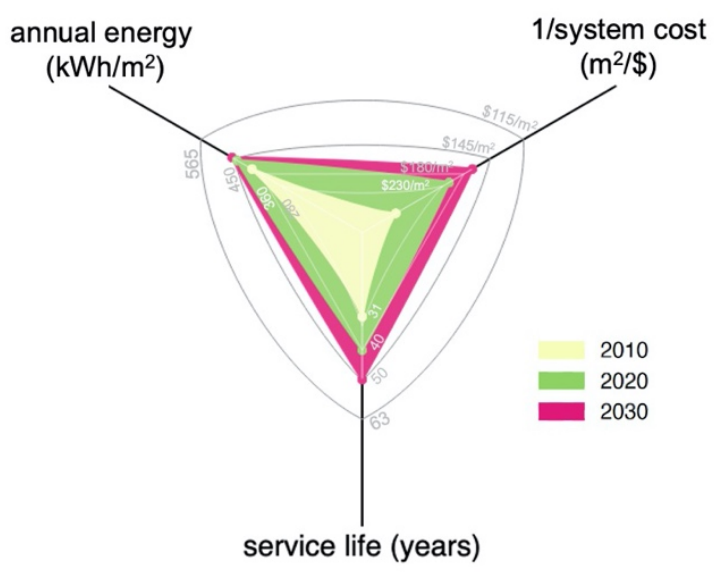

bifacial PERC

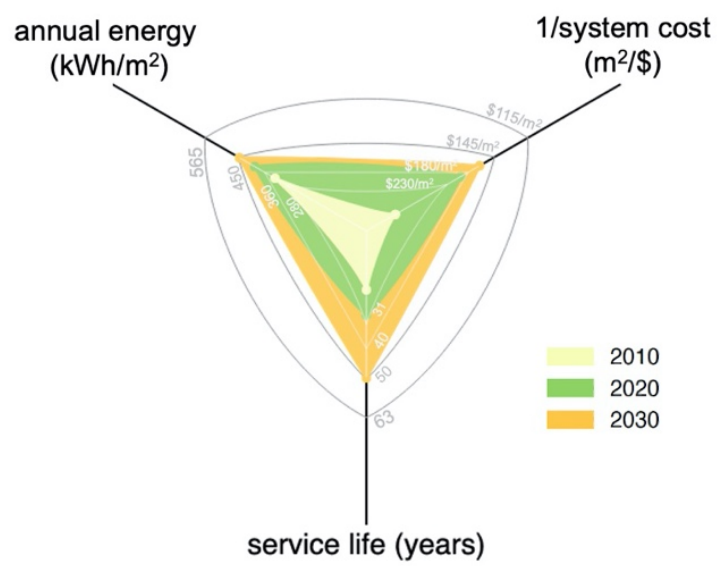

bifacial PERT/PERL

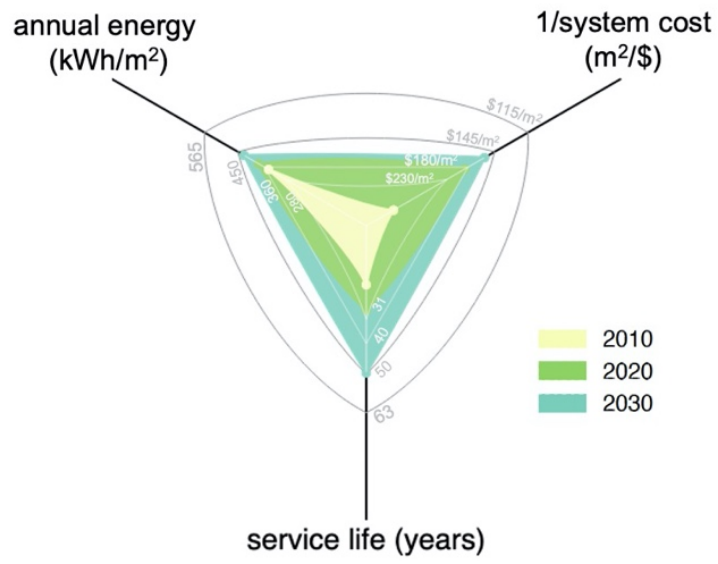

bifacial SHJ

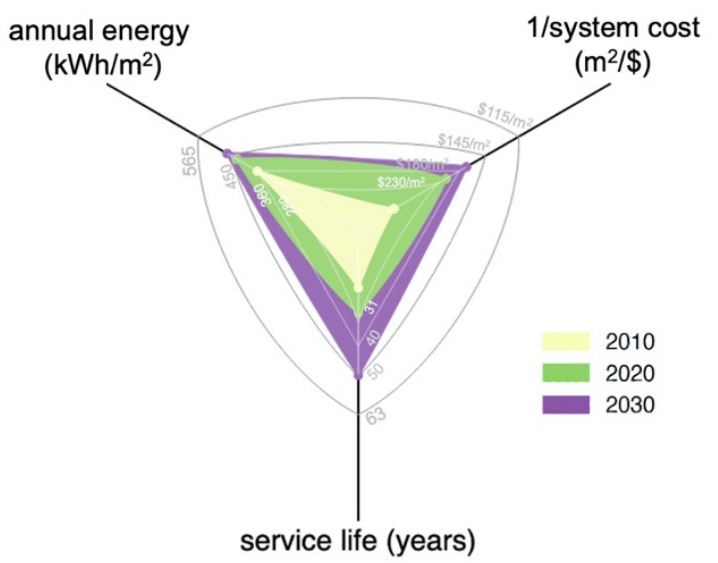

Figure 14. TEF plots for C-Si PV systems: monofacial monocrystalline PERC, bifacial monocrystalline PERC, IBC, bifacial PERT/PERL, and bifacial SHJ 


\subsection{Cadmium Telluride (CdTe)}

PV module manufacturing is highly competitive, and module prices have declined by a factor of 10 over the past decade, largely because the c-Si supply chain has increased production by a factor greater than 20 over the same timeframe (Mints April 2019). In this competitive environment, most thin-film PV manufacturers have been unable to reduce costs at the same pace as market pricing and have had to cease operations. One notable exception is First Solar, which has produced price-competitive CdTe modules with demonstrated reliability in the outdoor environment and is now the largest thin-film PV manufacturer in the world.

A summary of global CdTe manufacturing capacity is reported in Table 3 . Of the $2 \mathrm{GW}$ of fully integrated module capacity in the United States, 70\% came online during 2019-2020. Historically, First Solar has targeted utility-scale applications. In late 2020, CdTe PV manufacturer Toledo Solar began production at a 100-MW capacity facility in the United States, intending to target the residential PV market.

Table 3. Summary of Global CdTe Module Manufacturing and Cumulative Installations in 2020

\begin{tabular}{lll}
\hline Location & Annual Manufacturing Capacity & Cumulative Installations, 2020 \\
\hline United States & $2 \mathrm{GW}$ & $>12 \mathrm{GW}$ \\
Globally & $7.6 \mathrm{GW}$ (U.S., Malaysia, \& Vietnam) & $>20 \mathrm{GW}$ \\
\hline
\end{tabular}

CdTe cell and module efficiencies have also advanced. Through consistent investments in R\&D, a record CdTe PV cell efficiency of $22.1 \%$ and champion module efficiency of $18.6 \%$ have been achieved (Figure 15). Commercial production module efficiencies have reached a maximum of $18.2 \%$ - approximately double the maximum available in 2006.

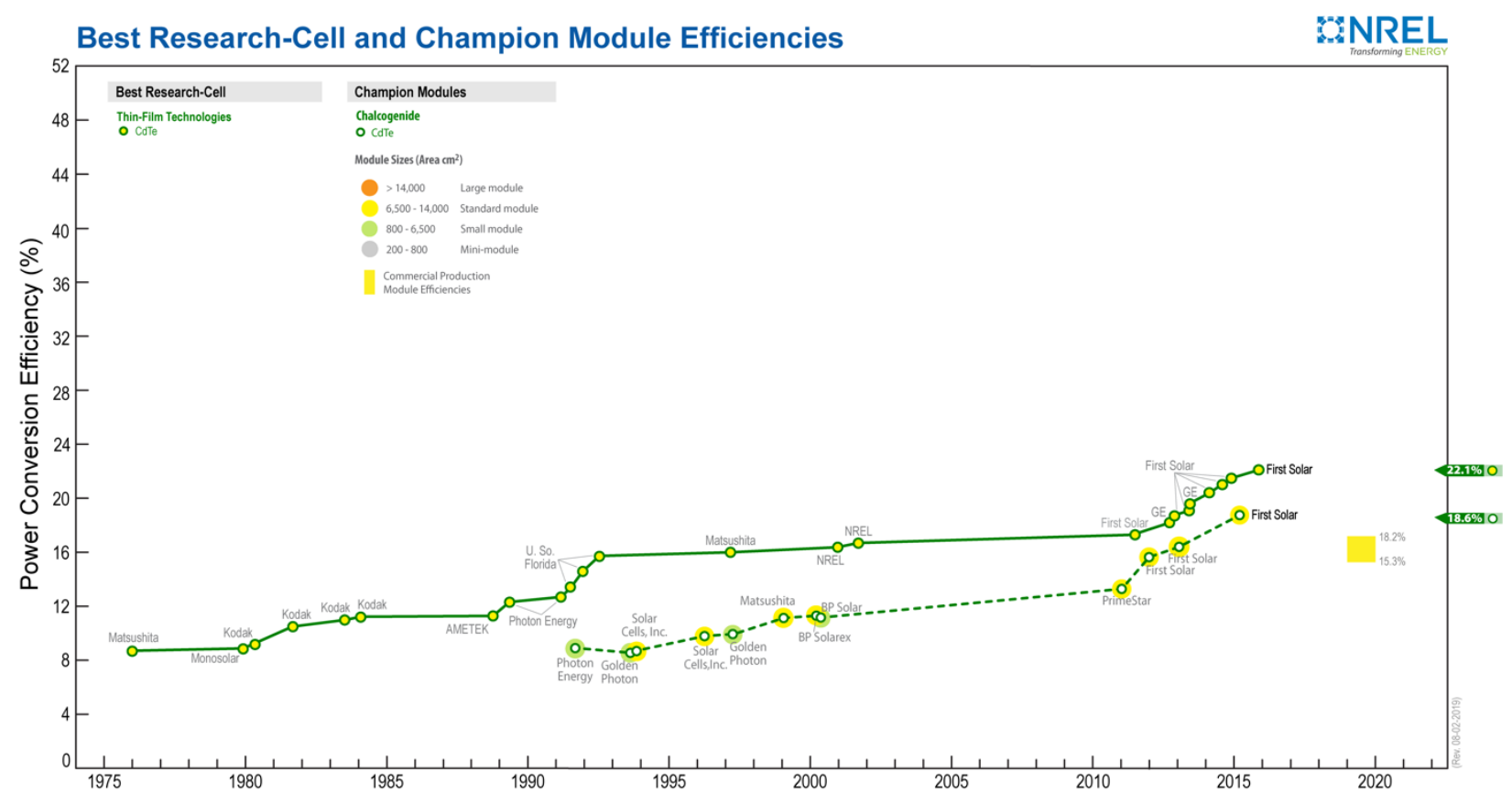

Figure 15. CdTe cell and module efficiency progress

CdTe PV modules have been operating reliably and safely at NREL's outdoor test facility in Golden, CO, for more than 2 decades. Series 6 modules successfully pass all of the International 
Electrotechnical Commission (IEC) 61215 and 61730 tests up to 1,500 V and the UL 1703 test up to $1,500 \mathrm{~V}$. Being able to withstand higher system voltages can reduce system costs by eliminating combiner boxes, reducing the number of transformers needed, and eliminating photovoltaic combining switchgears (PVCS). Reliability tests conducted by independent testing labs affirm that CdTe is resistant to potential-induced degradation, and First Solar offers a warrantied annual degradation of $0.5 \%$ per year for Series 6 .

Relative to standard full-area Al-BSF and monofacial PERC c-Si, there are potential LCOE-level benefits for employing CdTe modules. These benefits include improved total system lifetime energy yield through enhanced spectral response to diffuse light and a lower temperature coefficient. In total, these two effects may impart a 5\%-8\% advantage in energy yield relative to standard Al-BSF multicrystalline-based Si (Kinsey 2015). However, energy yield advantages are not expected for CdTe in colder latitudes.

Our first fully detailed study of the commercial CdTe processing sequence and bottom-up manufacturing costs analysis was completed in 2013 (Woodhouse, Goodrich et al. 2013). We still use the same basic layer stack first described in that publication but have added further details shown in Figure 16.

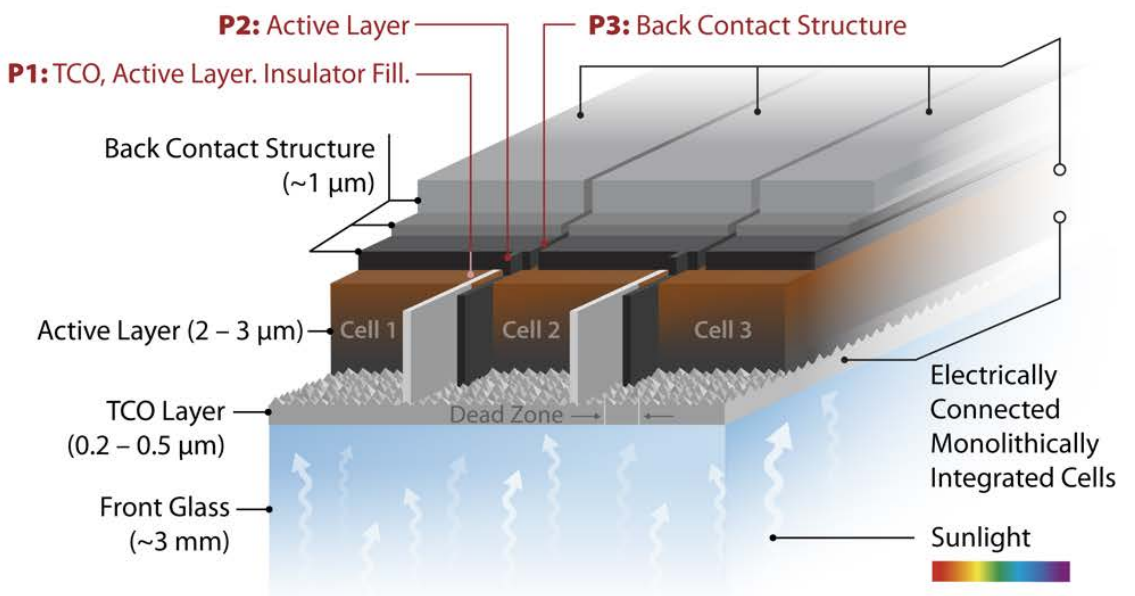

Thin Film Module

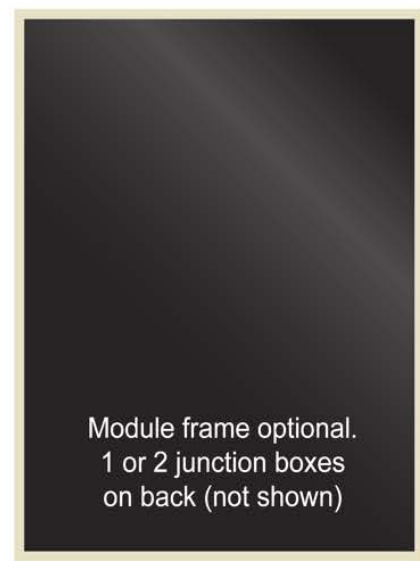

AM1.5 = air mass 1.5.

Figure 16. Device stack for CdTe cells built by monolithic integration

To enable high-temperature material growth, CdTe devices are generally manufactured in the "superstrate" configuration (Compaan 2006): The layers are stacked atop heat-stabilized front glass, with the module turned over at installation. When the module is deployed, sunlight enters via the front glass and transparent conducting oxide (TCO) layers before encountering the CdTe active layer. The individualized cell pattern in Figure 16 depicts the result of monolithic integration, which is achieved by laser and mechanical scribes. Actual cells are much wider relative to the size of the scribes in the figure. Cell sizes are optimized for maximum module efficiency by considering tradeoffs between series resistance and dead-zone losses: Larger cells reduce total module dead-zone losses but experience greater series resistance losses, whereas smaller cells increase total module dead-zone losses because the device inactive areas grow commensurately with the number of laser scribes. 


\subsubsection{Process Flows and Costs by Step}

Our step-by-step cost model for CdTe is based on the processing sequence shown in Figure 17, which is based on a model factory layout that uses wet chemical and dry deposition processes to deposit the materials shown. The materials used for the post-CdTe deposition steps-including the $\mathrm{CdCl}_{2}$ activation, $\mathrm{Cu}$ diffusion, screen-printed doped carbon paste, and vacuum-deposited adhesion and barrier layers - are selected for the sake of CdTe grain boundary passivation and the desired electrical junction characteristics for effective charge carrier extraction. Materials such as $\mathrm{CdS}, \mathrm{MgZnO}$, or ZnTe are often included as window layers or rear carrier reflectors prior to the P1 scribe, but this varies depending on the manufacturer. Additional materials used to assemble modules include an encapsulant, edge seals, heat-strengthened back glass, a metallic busbar array for connecting cells across the module, and a junction box for connecting modules into strings during installation.

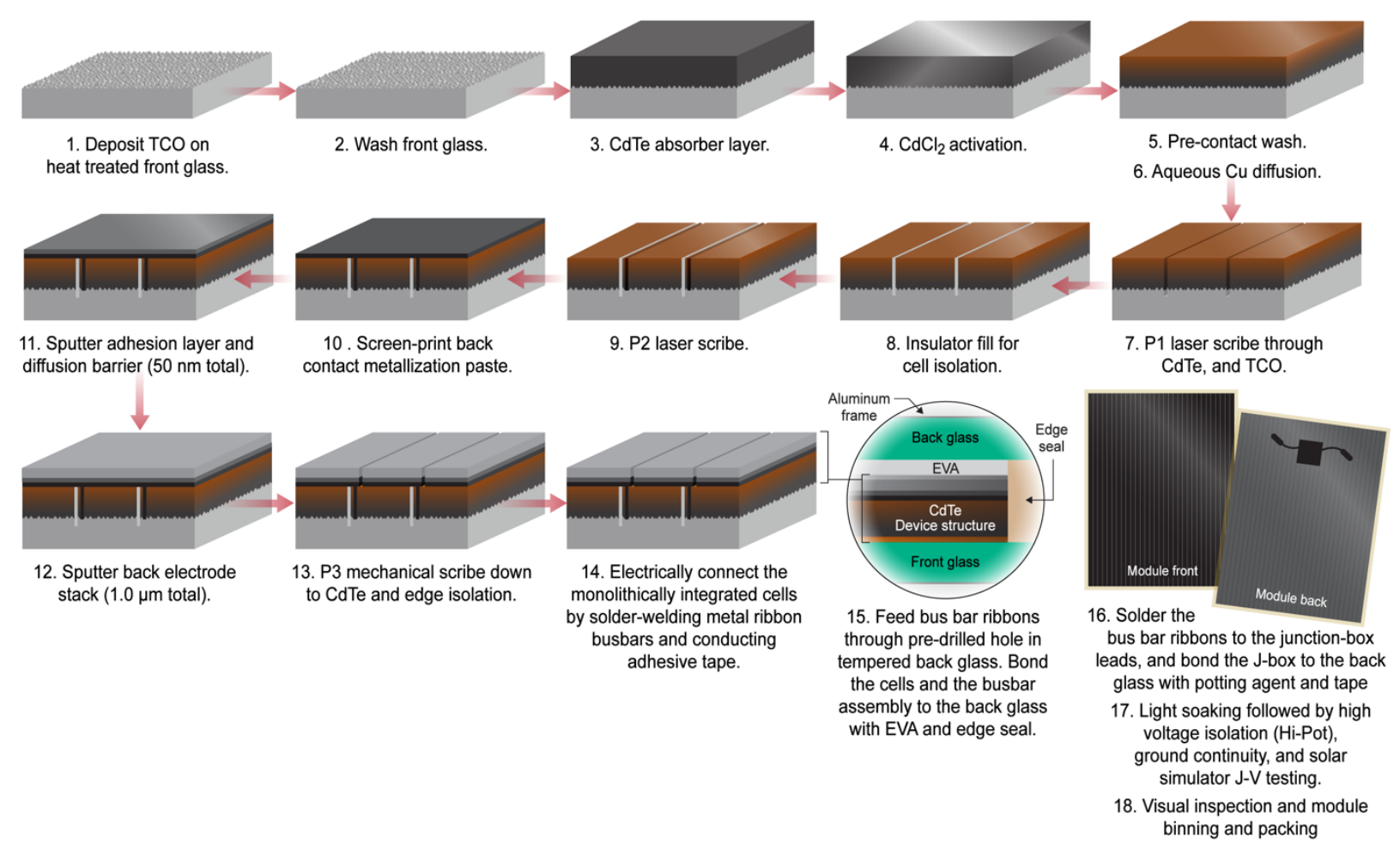

Figure 17. Process flow flow used for NREL's CdTe manufacturing cost model

Figure 18 shows CdTe module costs aggregated by major process steps, and Table 4 provides an overview of the module cost model inputs. 


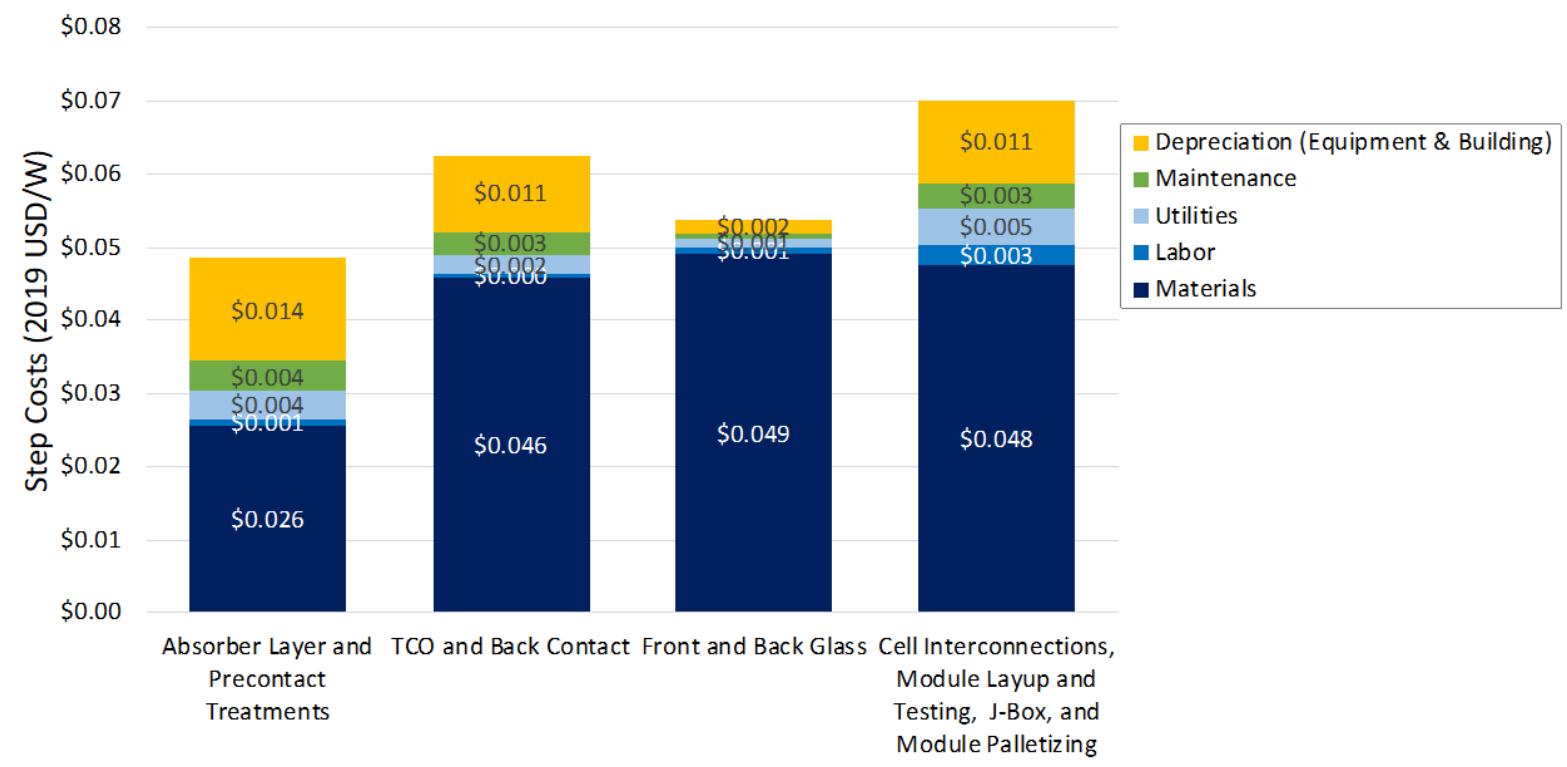

Figure 18. Costs aggregated by major steps for Series $6 \mathrm{CdTe}$ module production in Southeast Asia, 2-GW facility for $2.47-\mathrm{m}^{2}$ modules at $18 \%$ efficiency

Table 4. Summary of Inputs Used in NREL's CdTe Module Cost Model

\begin{tabular}{|c|c|}
\hline \multicolumn{2}{|l|}{ Variable COGS Inputs } \\
\hline $\begin{array}{l}\text { Principal input } \\
\text { materials }\end{array}$ & $\begin{array}{l}2 \text { sheets of glass: heat strengthened, with an anti-reflection coating on the } \\
\text { front glass, } 1 \text { sheet of encapsulant, wet chemical and dry compound } \\
\text { precursors, and balance-of-module materials (junction box, anodized Al } \\
\text { frame, edge sealant, barcoded module sticker label, and packaging } \\
\text { materials). }\end{array}$ \\
\hline Labor & $0.4-0.6$ total direct employees per MW of annual production. \\
\hline Electricity & 75-80 kWh per module. \\
\hline Maintenance & Annual cost corresponding to $4 \%$ of the original investment in equipment. \\
\hline \multicolumn{2}{|l|}{ Fixed COGS Inputs } \\
\hline $\begin{array}{l}\text { Equipment CapEx } \\
\text { and depreciation }\end{array}$ & $\begin{array}{l}\text { Total equipment CapEx of } \$ 0.25-\$ 0.30 / \mathrm{W} \text { for } 2020 \text { baseline } 430-\mathrm{W} \text { Series } \\
6 \text { modules having a } 2.47-\mathrm{m}^{2} \text { total area. This is allocated across the } \\
\text { equipment for buffer and absorber layers }(\$ 0.08-\$ 0.09 / \mathrm{W}) \text {, back contact } \\
(\$ 0.11-\$ 0.12 / \mathrm{W}) \text {, monolithic integration }(\$ 0.02-\$ 0.03 / \mathrm{W}) \text {, and final } \\
\text { module assembly ( } \$ 0.04-\$ 0.05 / \mathrm{W}) .7 \text {-year depreciation assuming the } \\
\text { same useful lifetime. }\end{array}$ \\
\hline $\begin{array}{l}\text { Facilities CapEx and } \\
\text { depreciation }\end{array}$ & $\begin{array}{l}\$ 0.03-\$ 0.06 / \mathrm{W} \text { total for new facility and building CapEx. } 20 \text {-year } \\
\text { depreciation (straight line). }\end{array}$ \\
\hline \multicolumn{2}{|c|}{ Remaining Fixed Operating Expenses } \\
\hline R\&D & $3 \%$ of revenues \\
\hline SG\&A & $9 \%$ of revenues \\
\hline
\end{tabular}




\subsubsection{Benchmark Costs and Technology Roadmap}

Our 2020 benchmark MSP for sheet-to-sheet (S2S) CdTe module manufacturing is shown in Figure 19. This benchmark assumes a gross margin of $15 \%$; error bars show gross margins of $25 \%$ (high MSP) and 5\% (low MSP).

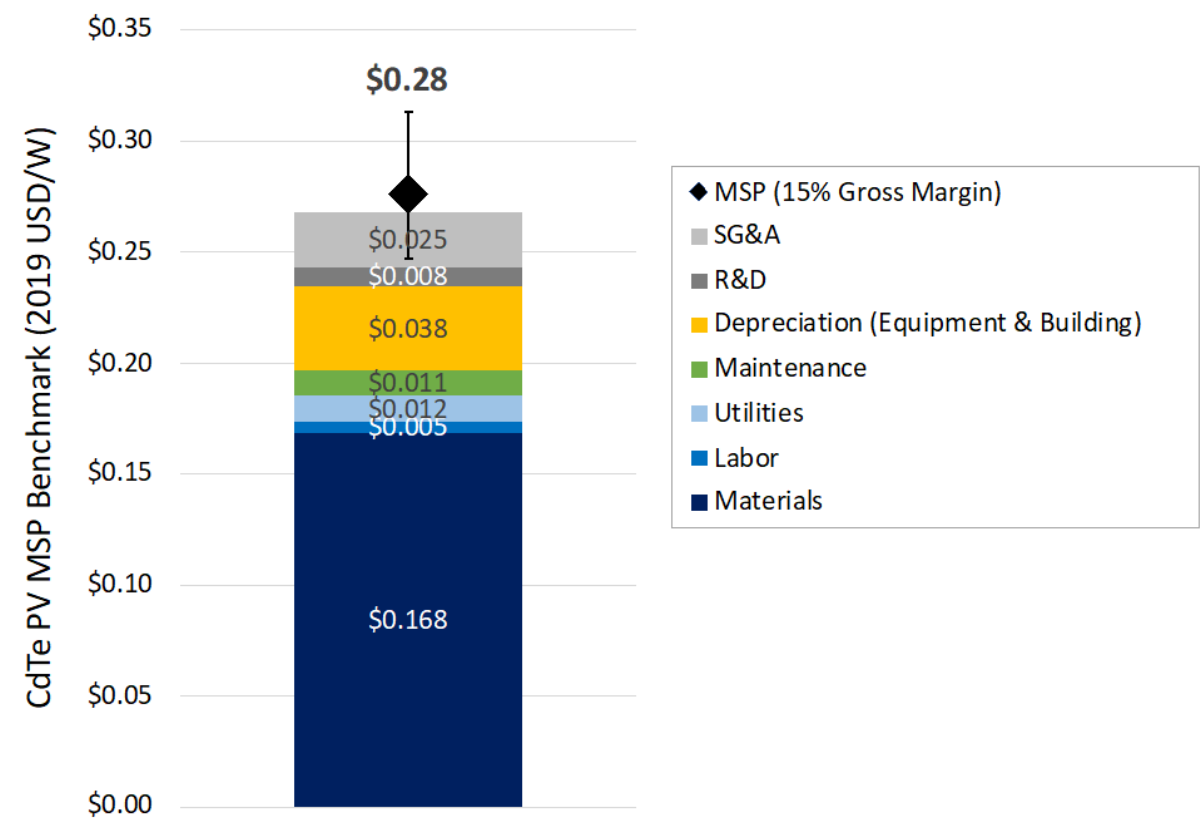

Figure 19. CdTe PV module MSP benchmark for production in Southeast Asia, 2020

A roadmap for future CdTe PV technology progress is shown in Figure 20. Module efficiency improvements have been achieved through concerted efforts between equipment providers and R\&D teams at universities, national laboratories, institutes across the globe, and First Solar. The primary scientific challenges for CdTe as a material set include doping profile and film uniformity, as well as reducing recombination at interfaces and grain boundaries (Moseley, Rale et al. 2018). Improving film uniformity is assumed to enable module efficiencies that match the small-area efficiency record of $22 \%$ reported in Figure 15. This, in combination with reducing CdTe layer thickness, is expected to contribute to an MSP of $\$ 0.22 / \mathrm{W}$ by 2025 . Addressing recombination challenges is anticipated to achieve $25 \%$ efficiency and an MSP of $\$ 0.19 / \mathrm{W}$ past 2025. The MSP projections shown in Figure 20 are based on technology advancements only. Economies of scale resulting from sustained technology success and growth may also enable lower future costs, but the potential influence from this factor is not included in Figure 20. 


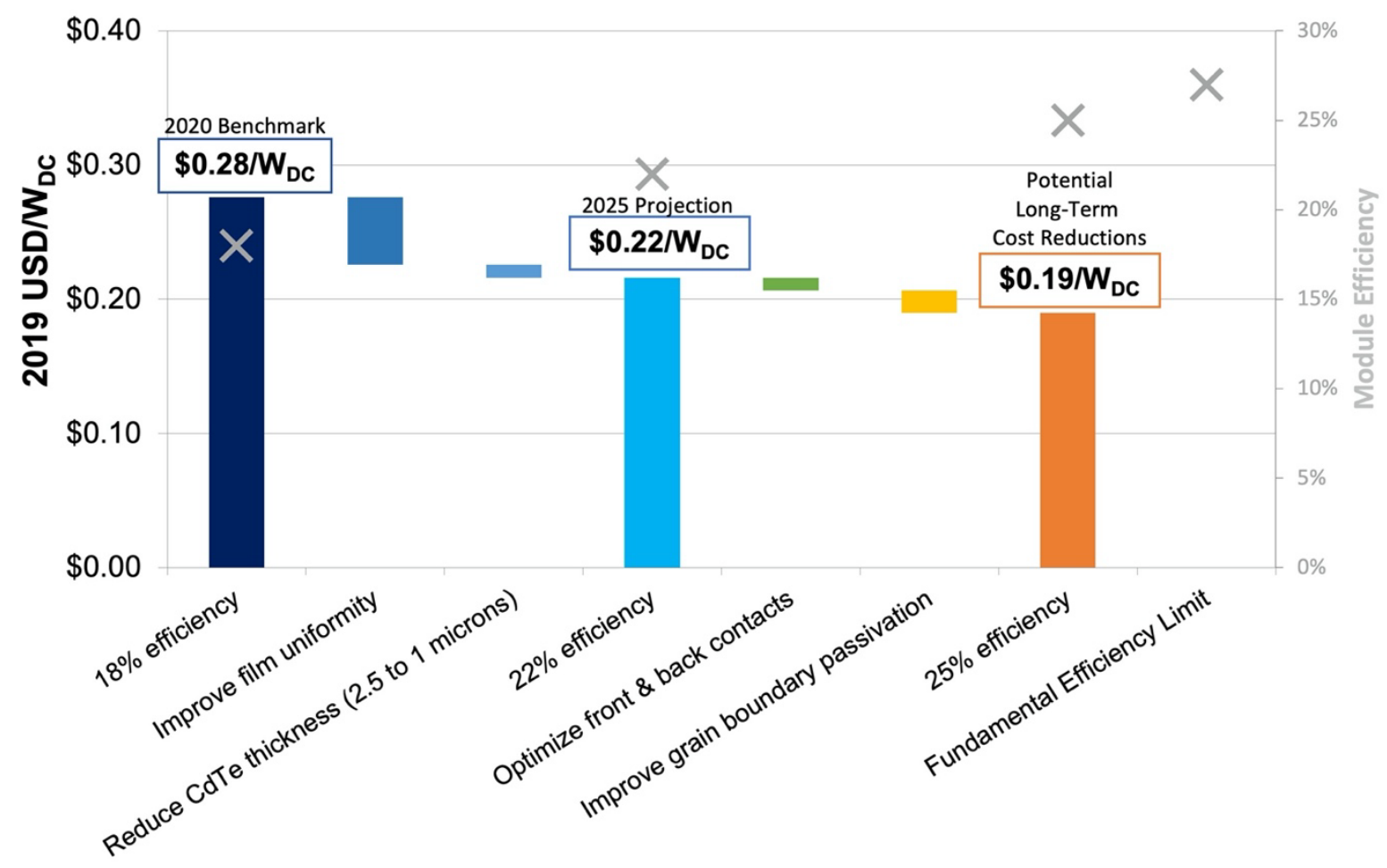

The TEF plot for CdTe PV systems is shown in Figure 21. Historical cost modeling results from NREL (Woodhouse, Goodrich et al. 2013) serve as a primary reference point for the 2010 cost and energy data, while 2020 and 2030 data reflect the cost model results from our current work. These data, as well as other metrics such as power temperature coefficients and degradation rates over time, were determined via discussion with experts at the 2020 NREL TEF Workshop (National Renewable Energy Laboratory 2020). Given the challenges associated with CdTe reaching the long-term potential efficiency (Kanevce, Reese et al. 2017), we assume that the technology will not reach $25 \%$ efficiency by 2030 and will instead need to progress further along the system cost axis to achieve the target LCOE of 3 cents $/ \mathrm{kWh}$.

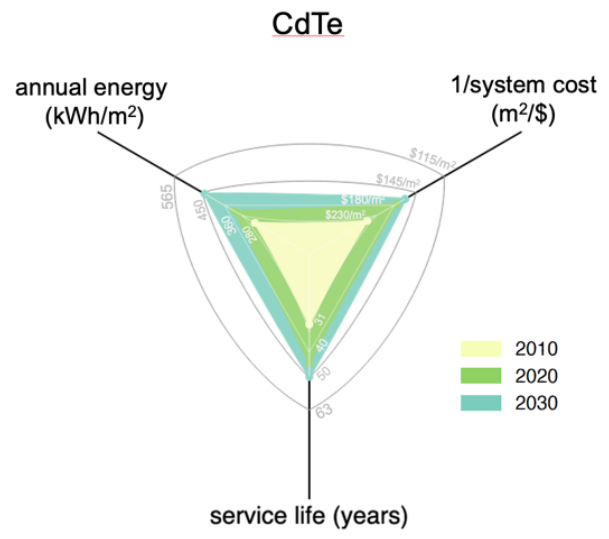

Figure 21. TEF plot for CdTe PV systems 


\subsection{Copper Indium Gallium (Di)selenide (CIGS)}

CIGS PV has been produced commercially since the 1990s, and approximately $2 \mathrm{GW}$ of annual CIGS manufacturing capacity are active today (Table 5). The largest CIGS manufacturer is the Japanese company Solar Frontier. Solar Frontier has over 900 MW of production at its Kunitomi factory, at which it has been consolidating production over the last several years. Solar Frontier currently focuses on mainstream PV markets - including residential rooftop, commercial, and utility-scale markets - and it produces the CIGS layer using a two-stage sputtering plus batch selenization and sulfurization (SAS) process.

China has recently moved into the CIGS space as well. The Chinese National Building Material Company (CNBM) acquired Avancis and installed $300 \mathrm{MW}$ of production capacity in China, with plans to install a total of $1.5 \mathrm{GW}$ there. The Shenhua Group acquired the CIGS technology developed at Manz and ZSW and is constructing $300 \mathrm{MW}$ of production capacity in China. The three CIGS companies under Hanergy_Miasolé, Global Solar Energy, and Solibro — had plans to install hundreds of MW of capacity using each company's technology in China, aiming for a total capacity of over $3 \mathrm{GW}$. However, financial issues at Hanergy resulted in mass layoffs across the companies in 2019 and 2020; production remains halted with some equipment auctions occurring in late 2020 .

Table 5. Summary of Current CIGS Module Manufacturing

\begin{tabular}{ll}
\hline 2019 global active annual production capacity & $\sim 2 \mathrm{GW}$ \\
\hline Manufacturing locations & $\begin{array}{l}\text { Japan, Germany, China, South Korea, United } \\
\text { States, Switzerland }\end{array}$ \\
\hline Commercial methods for CIGS layer deposition & $\begin{array}{l}\text { Sputtering plus batch SAS (largest share of } \\
\text { production) }\end{array}$ \\
& $\begin{array}{l}\text { Sputtering plus rapid thermal processing } \\
\text { (RTP) SAS }\end{array}$ \\
& - 1 -stage in-line co-evaporation process \\
- & 3-stage co-evaporation process \\
\hline
\end{tabular}

CIGS technology is not standardized in terms of product or process. Multiple different device stacks are in production today, the most common of which are shown in Figure 22. Different companies deposit the layers using different techniques (see Section 3.3.1). Thicknesses of the layers can also vary by company and process. The dominant architecture for CIGS is monolithically integrated modules, which may use a variety of substrate materials including glass, metal foils, and plastics. Most modules produced today are deposited on glass and have a rigid, glass-glass configuration. 


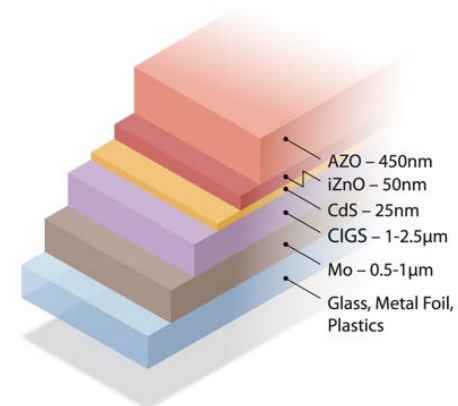

A

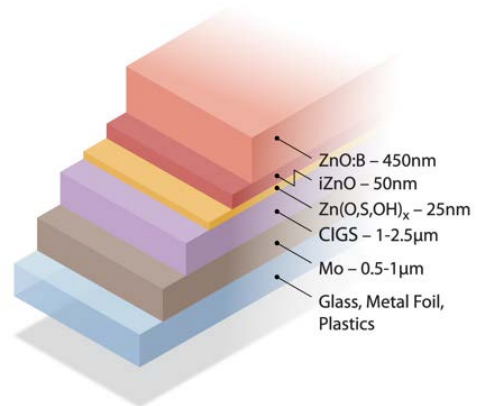

B

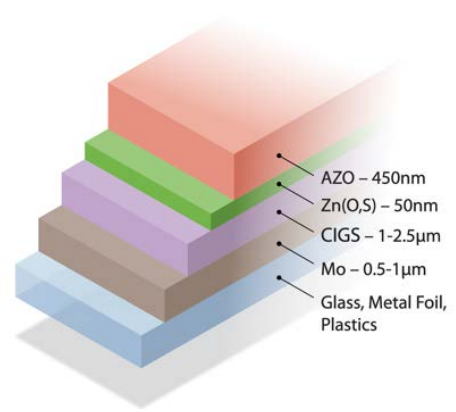

C

$\mathrm{AZO}=\mathrm{Al} \mathrm{Zn}$ oxide, $\mathrm{iZnO}=$ intrinsically doped $\mathrm{Zn}$ oxide.

Figure 22. Different CIGS device stacks used today (thicknesses of individual layers can vary)

Although aperture-area record efficiencies for small CIGS devices in the lab are now above 23\%, champion module efficiencies are still near $19 \%$, while full-area, ${ }^{1}$ fleet-average production efficiencies for commercially available products range from $12 \%$ to $16 \%$ (Figure 23 ).

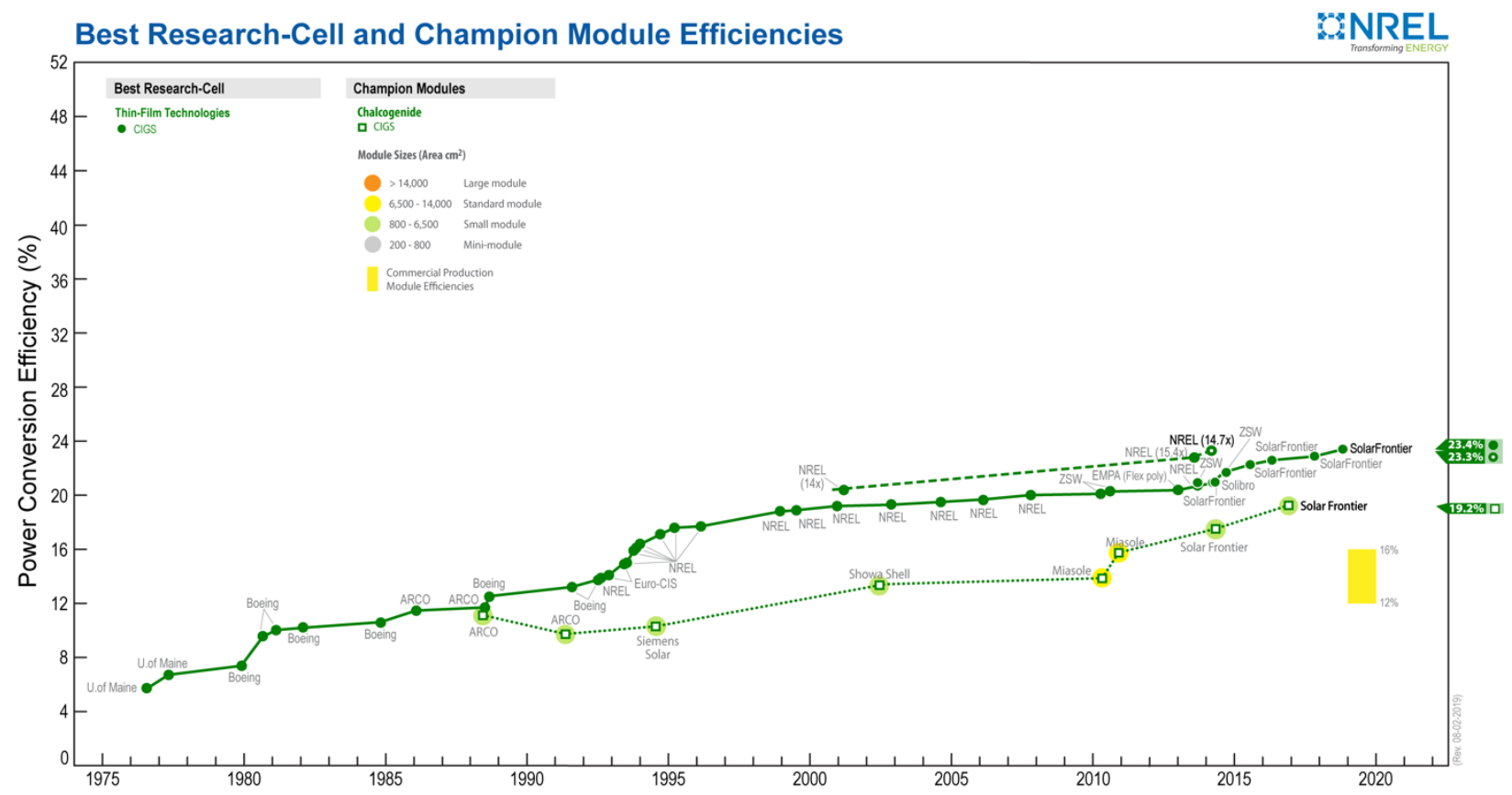

Figure 23. CIGS cell and module efficiency progress

\subsubsection{Process Flows and Costs by Step}

Figure 24 shows the general process flow used for producing monolithic, glass-glass CIGS modules. The two parallel paths represent the two classes of techniques used to fabricate the CIGS layer itself: sputter plus SAS and co-evaporation. Within each of those classes, there are

${ }^{1}$ CIGS efficiencies are often reported for the aperture area only, which does not include losses due to dead area and shading of the module interconnections and edge or frame. 
variations on the processes used. For example, single-stage or three-stage co-evaporation can be used, and SAS may occur either in a batch or in-line RTP process.

In addition to variations in processing the CIGS layer, different approaches are taken to deposit the buffer and TCO layers. Buffer layers are typically deposited using either a dry sputtering process or a wet chemical bath deposition (CBD) process. CdS and $\mathrm{Zn}(\mathrm{O}, \mathrm{S})$, common buffer layer materials, may be deposited using either approach. Various InS-based buffer layers have also been used, and these are sometimes thermally evaporated. The TCO is typically produced by sputtering, but Solar Frontier uses a customized metal organic vapor phase epitaxy (MOVPE) process instead for both the TCO and the window layer. The other steps in the process flow are more standardized across companies.

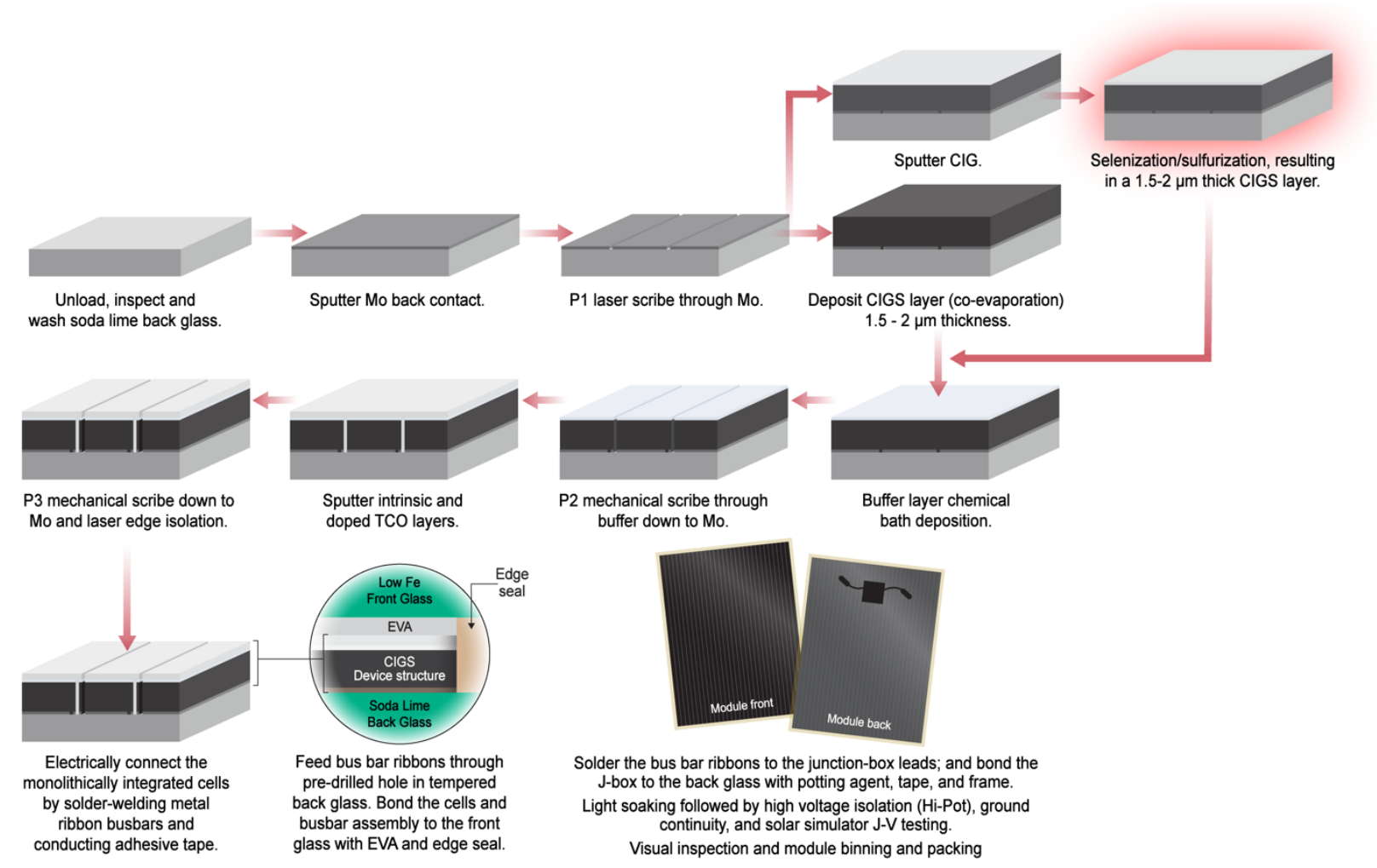

Figure 24. Process flows for manufacturing glass-glass monolithic CIGS modules

The parallel paths for the CIGS layer represent different approaches that are being taken in production, including several sputtering plus selenization and co-evaporation processes. MOCVD = metal organic chemical vapor deposition.

We model step-by-step costs associated with production of reference design A shown in Figure 22, assuming a 1.5- $\mu \mathrm{m}$ CIGS absorber layer, a 500-nm Mo layer, and a 1.65-m x 0.65-m module. We assume the two-stage sputtering plus batch SAS process is used for the CIGS layer, CBD of CdS for the buffer layer, and sputtered AZO for the top TCO. The results for a $16 \%$-efficient module are shown in Figure 25, with the inputs summarized in Table 6.

The batch SAS step is the most expensive step, driven both by the very low throughput of the SAS process (requiring many furnaces and associated high costs of depreciation, labor, and maintenance) as well as the cost of the $\mathrm{H}_{2} \mathrm{Se}$ and $\mathrm{H}_{2} \mathrm{~S}$. Alternative processes, including co- 
evaporation and RTP SAS, can be lower cost, but scale, yield, and efficiency will also influence the total module cost using these other approaches.

Glass, which has decreased in cost over the last several years, is still a major contributor to cost. Although some companies are looking to reduce cost by moving to thinner glass, these options are not currently cheaper owing to production scale and yield. The use of alternative flexible substrates, including polymers, also does not result in lower-cost modules today. In fact, flexible packaging is currently much more expensive than glass $\left(\$ 20-\$ 40 / \mathrm{m}^{2}\right)$ because of the small scale of production as well as the demands for packaging that allows minimal moisture ingress to avoid damage to the CIGS material.

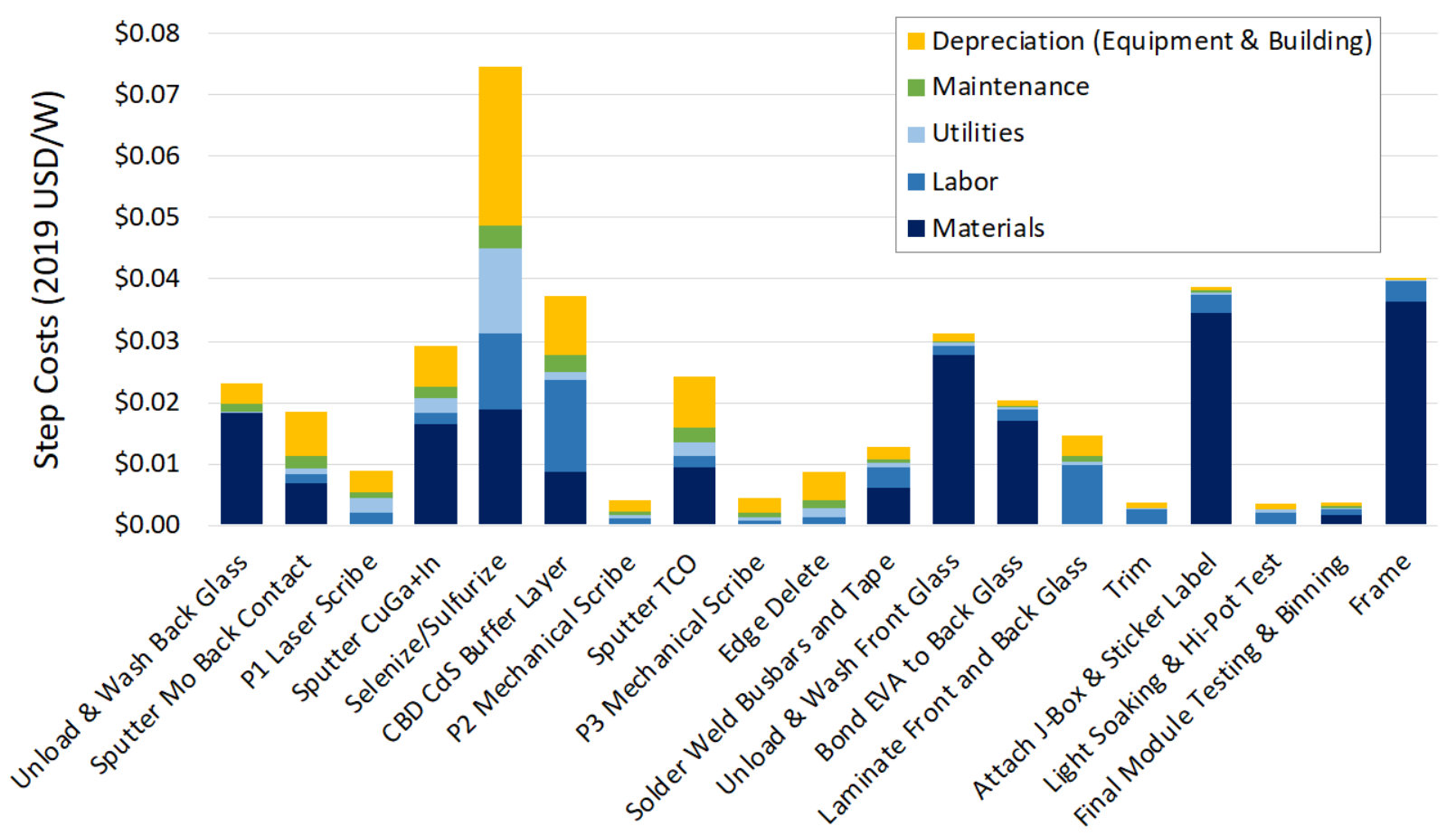

Figure 25. Step-by-step costs for CIGS reference design A, where the CIGS layer is produced using the two-step sputtering plus SAS process

A $15 \%$ module efficiency is assumed, with Japanese input data for materials, utilities, and labor costs at $900 \mathrm{MW}$ of annual production volume. Total manufacturing costs are $\$ 0.40$ per W direct current $\left(\mathrm{W}_{\mathrm{DC}}\right)$ or $\$ 61 / \mathrm{m}^{2}$. These costs do not reflect those of any particular company but are intended to approximately benchmark CIGS technology and illustrate key cost drivers.

Other balance-of-module costs also contribute significantly to overall costs, including costs of the junction box and frame. Frameless CIGS modules are sold in the market today and can be installed with slight modifications to the installation design and process. A single junction box is used per module; thus, as the power per module increases by increasing the efficiency and/or module area, junction box costs will decrease.

Reported pricing for cell and balance-of-module materials varies significantly depending on the supplier, purchase scale or contract, and region of the world. In some cases, Chinese suppliers quote materials at half the price of U.S., European, and Japanese suppliers. However, some module manufacturers still choose to source materials from outside of China for various reasons. 
Costs also depend on the location of suppliers and CIGS manufacturers as well as exchange rates. Finally, material prices — particularly for Ga and In - fluctuate substantially over time.

Table 6. Summary of Inputs Used in NREL's CIGS Module Cost Model

\begin{tabular}{|c|c|}
\hline \multicolumn{2}{|c|}{ Product Details (in addition to reference design A in Figure 22) } \\
\hline Cell & 1.5- $\mu \mathrm{m}$ CIGS absorber layer, 500-nm Mo layer \\
\hline Module & $1.65-\mathrm{m} \times 0.65-\mathrm{m}$ module \\
\hline \multicolumn{2}{|c|}{ Variable COGS Inputs for Fully Integrated Module Conversion } \\
\hline $\begin{array}{l}\text { Principal input } \\
\text { materials }\end{array}$ & $\begin{array}{l}\text { Glass, deionized water, Mo sputtering target (rotary), } \mathrm{H}_{2} \mathrm{Se}, \mathrm{H}_{2} \mathrm{~S}, \mathrm{~N}_{2} \text {, } \\
\mathrm{Cu}_{0.75} \mathrm{Ga}_{0.25} \text { sputtering target (rotary), In sputtering target (rotary), } \mathrm{CdSO}_{4} \text {, } \\
\mathrm{CS}\left(\mathrm{NH}_{2}\right)_{2}, \mathrm{NH}_{4} \mathrm{OH}, \mathrm{NH}_{4} \mathrm{C}_{2} \mathrm{H}_{3} \mathrm{O}_{2}, \mathrm{AZO} \text { sputtering target (rotary), inO } \\
\text { sputtering target (rotary), Cu ribbon, Sn and In solder, EVA, Al framing } \\
\text { materials, junction box, and pottant. }\end{array}$ \\
\hline Labor & $\begin{array}{l}0.75 \text { employees per MW of annual production at volume assumed in } \\
\text { results shown here (varies in industry). }\end{array}$ \\
\hline Electricity & Total of $32 \mathrm{kWh}$ per module. \\
\hline Maintenance & $\begin{array}{l}\text { Annual cost corresponding to } 3.6 \% \text { of the original investment in } \\
\text { equipment, assuming new equipment. }\end{array}$ \\
\hline \multicolumn{2}{|c|}{ Fixed COGS Inputs for Fully Integrated Module Conversion } \\
\hline \multirow[t]{2}{*}{$\begin{array}{l}\text { Equipment CapEx } \\
\text { and depreciation }\end{array}$} & $\begin{array}{l}\text { 900-MW facility, two-stage sputtering plus batch SAS process for CIGS } \\
\text { layer, CBD of CdS for buffer layer, sputtered AZO for top TCO. }\end{array}$ \\
\hline & $\begin{array}{l}\text { Total equipment CapEx of } \$ 0.51 / \mathrm{W} \text { of annual capacity. } 7 \text {-year straight-line } \\
\text { depreciation. Assumed } \sim 90 \% \text { yield. }\end{array}$ \\
\hline $\begin{array}{l}\text { Facilities CapEx and } \\
\text { depreciation }\end{array}$ & $\begin{array}{l}\$ 0.05 / \mathrm{W} \text { for new (greenfield) facilities CapEx. 20-year depreciation } \\
\text { (straight line). }\end{array}$ \\
\hline \multicolumn{2}{|c|}{ Remaining Fixed Operating Expenses } \\
\hline R\&D & $3 \%$ of revenues \\
\hline SG\&A & $9 \%$ of revenues \\
\hline
\end{tabular}

Inputs vary by company, module design, and manufacturing processes used.

\subsubsection{Benchmark Costs and Technology Roadmap}

To benchmark the 2020 CIGS PV price structure, the costs by step shown in Figure 25 are aggregated as COGS, and a gross margin is applied to estimate the MSP. The benchmark price structure is shown in Figure 26. This benchmark assumes a gross margin of 15\%; error bars show gross margins of 25\% (high MSP) and 5\% (low MSP). This is the highest benchmark of the technologies in this section. However, several CIGS companies are focused on flexible PV designs targeted at specialty applications, including weight-constrained rooftops, solar shingles, portable PV, and outdoor recreation equipment. As such, the technology may not be directly competing with CdTe and c-Si technologies and their predominant markets. 


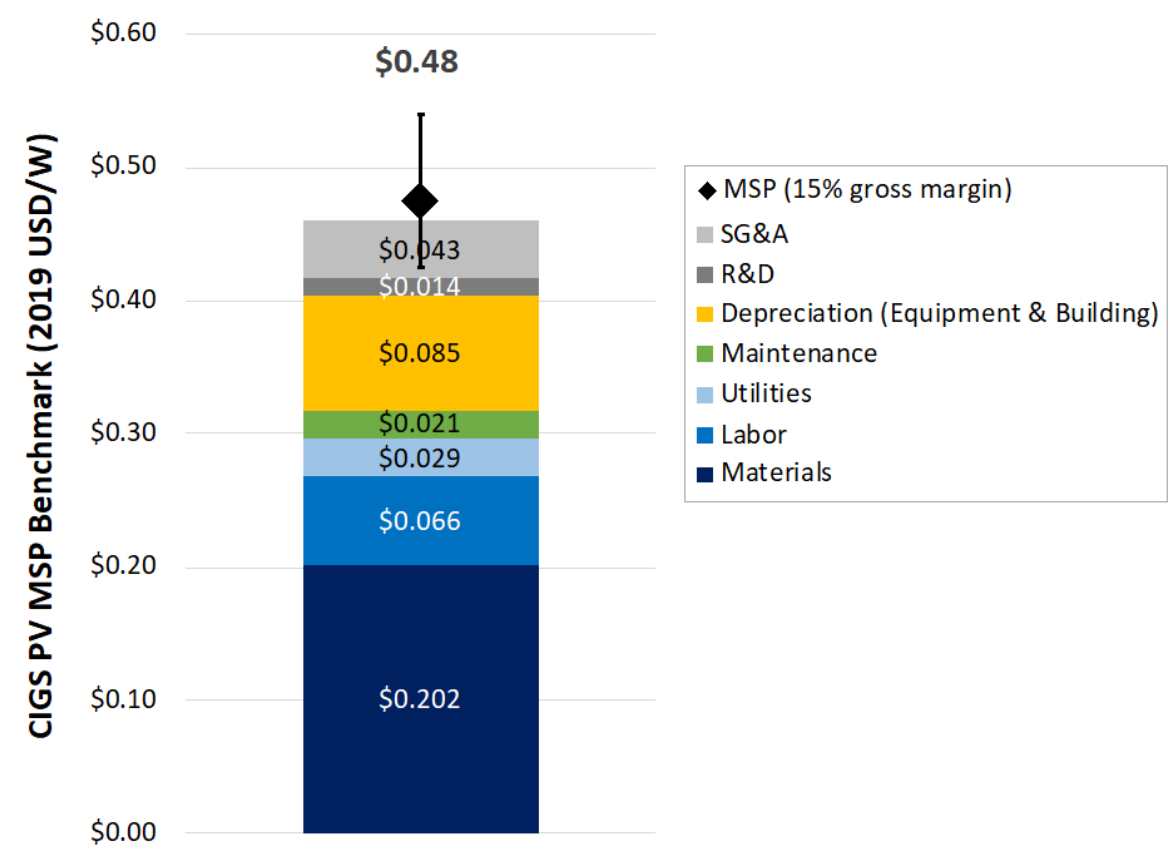

Figure 26. CIGS PV module MSP benchmark, 2020

A $16 \%$ module efficiency is assumed, with Japanese input data for materials, utilities, and labor costs. Results shown are for $900 \mathrm{MW}$ of annual production volume.

Figure 27 shows a potential roadmap to reduced CIGS module manufacturing costs from our benchmark of $\$ 0.48 / \mathrm{W}_{\mathrm{DC}}$. As mentioned above, frameless CIGS modules are available today, with both framed and frameless modules purchased in volume. Thus, the cost reduction due to frame removal is not applicable to all modules. Furthermore, the final step in the roadmap evaluates the impact of increasing module area, however this may reduce the ability to manufacture the module without a frame.

Increasing efficiency is a critical component of the CIGS roadmap. We break out the impacts of increasing from $16 \%$ to $18 \%$ efficiency in the near term and from $18 \%$ to $20 \%$ efficiency as a long-term target for full-area, average production CIGS module efficiencies. There are several pathways for increasing efficiency, including engineering processes so that small-area efficiencies such as those reported in Figure 23 are maintained over large areas and reducing the dead area (e.g., by moving toward laser scribing for all interconnects).

Increasing throughput of the CIGS deposition is also key to lower CIGS costs. A 15- to 20-fold increase in throughput may be achievable today in lower volumes using current co-evaporation or RTP SAS processes. Both cycle times and materials costs can also be decreased by reducing the thickness of the CIGS layer. The efficiency, yield, and scale of production for any highthroughput processes will strongly influence the degree of cost reduction achieved. Additional cost reductions might be achieved if CIGS production volumes increased, resulting from learning by doing and economies of scale. 


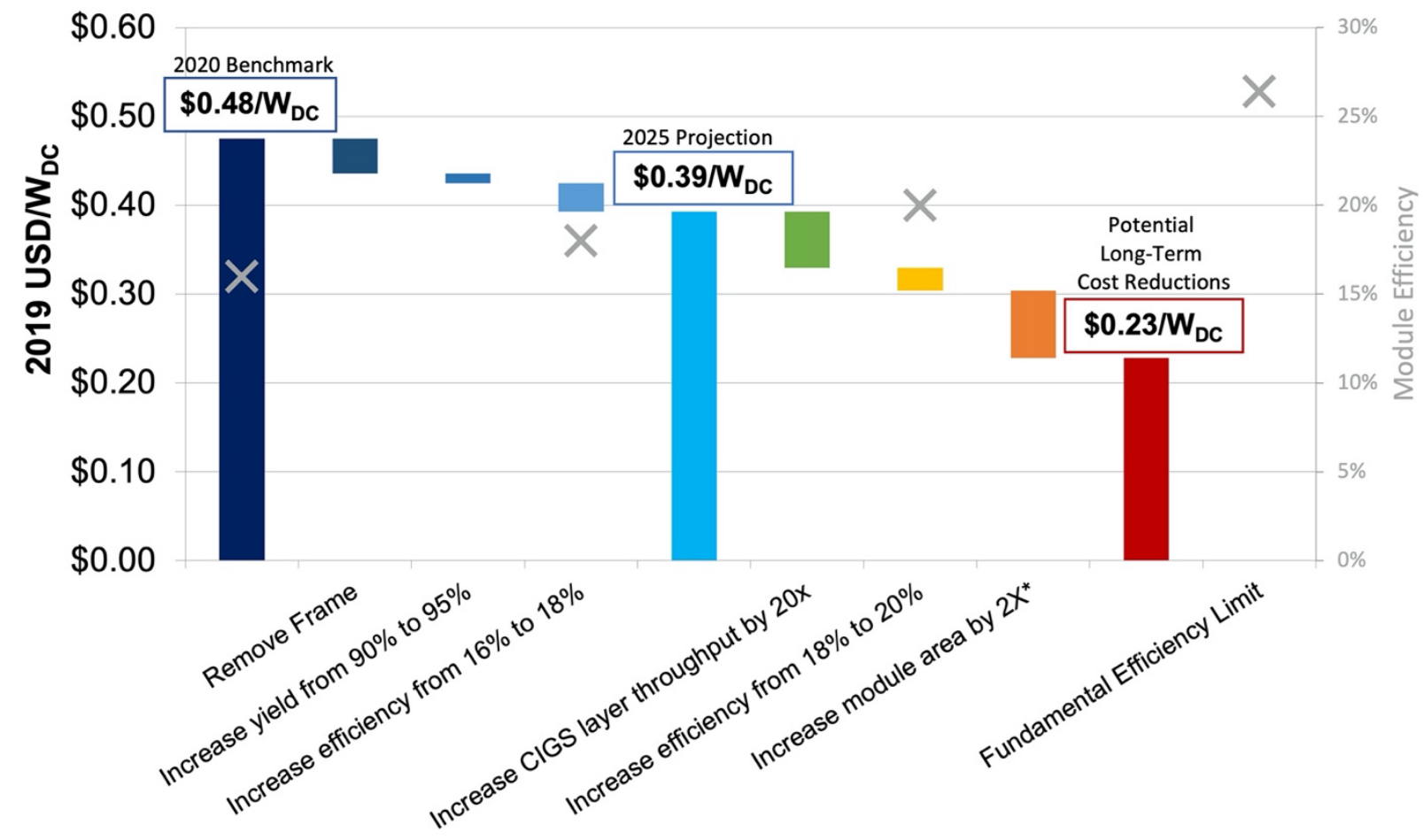

The TEF plot for CIGS PV systems is shown in Figure 28. Historical cost modeling results from NREL (Goodrich, James et al. 2011, Horowitz, Fu et al. 2016) serve as a primary reference point for the 2010 cost and energy data, while 2020 and 2030 data reflect the cost model results from our current work. These data, as well as other metrics such as power temperature coefficients and degradation rates over time, were determined via discussion with experts at the 2020 NREL TEF Workshop (National Renewable Energy Laboratory 2020). Because the CIGS roadmap shows significant limitations to long-term efficiency potential (Topič, Geisthardt et al. 2015), it must progress further down the cost axis than other technologies to reach the 3 cents $/ \mathrm{kWh}$ LCOE target for 2030.

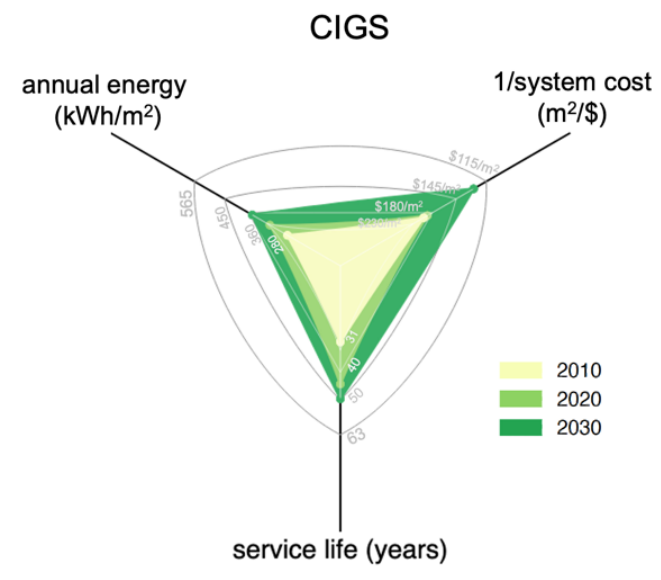

Figure 28. TEF plot for CIGS PV systems 


\section{PV Technologies at Small Scale or Pilot Production}

This section reviews PV technologies that have small-scale or pilot-scale production in 2020, namely III-Vs and perovskites. For each, we provide an overview of their most commonly used manufacturing methods and discuss their fit within the technology assessment criteria described in Section 2.2. We compile 2020 benchmark step-by-step costs for III-V cells into total cell production costs. We estimate 2020 step-by-step costs for perovskite module production at significantly larger scales than the pilot production occurring in 2020 . We compile these into an estimated module benchmark. We then conclude each section with roadmaps of future cost projections and each technology's past, present, and projected TEF scores.

\subsection{III-Vs}

III-V PV technologies date back to the 1970s and 1980s, when companies such as IBM and Varian performed early research. Commercial manufacturing of III-V cells began in the mid1990s for use in space applications. The technologies include multijunction devices that increase efficiency by stacking multiple semiconductor layers to capture more of the solar spectrum. Inverted metamorphic growth and epitaxial liftoff techniques have created flexible III-V devices with state-of-the-art efficiencies.

Today, III-Vs encompass the highest-efficiency PV products on the market. The current highest research-cell efficiency is $47.1 \%$ for a multijunction III-V device with solar concentration (Figure 29), and even higher efficiencies are possible. Terrestrial III-V devices with concentration also have some of the best laboratory-tested temperature coefficients; one study showed efficiency reductions of less than $0.2 \%$ per degree Celsius (Siefer and Bett 2014). However-despite historical cost reductions due to improved processing yields, processing techniques, and epitaxial deposition and the growth of complementary industries such as lightemitting diodes - standard III-V devices are orders of magnitude more expensive than current market-leading PV modules. The high cost has kept III-V technology in niche marketplaces, predominantly space applications but also terrestrial concentrator applications. Commercial and R\&D efforts aim to reduce costs and improve competitiveness in emerging and traditional markets. Even in the space market, III-V manufacturers are being pressured to innovate and reduce costs, because changes in launch technology have reduced the premium on light, highefficiency PV devices, and the efficiency gap between III-Vs and other PV technologies has decreased. Emerging markets for III-Vs include rapid deployment applications, drones (aerospace), vehicles, and wearables/military applications - small markets constituting less than $1 \%$ of the global PV industry by capacity. 


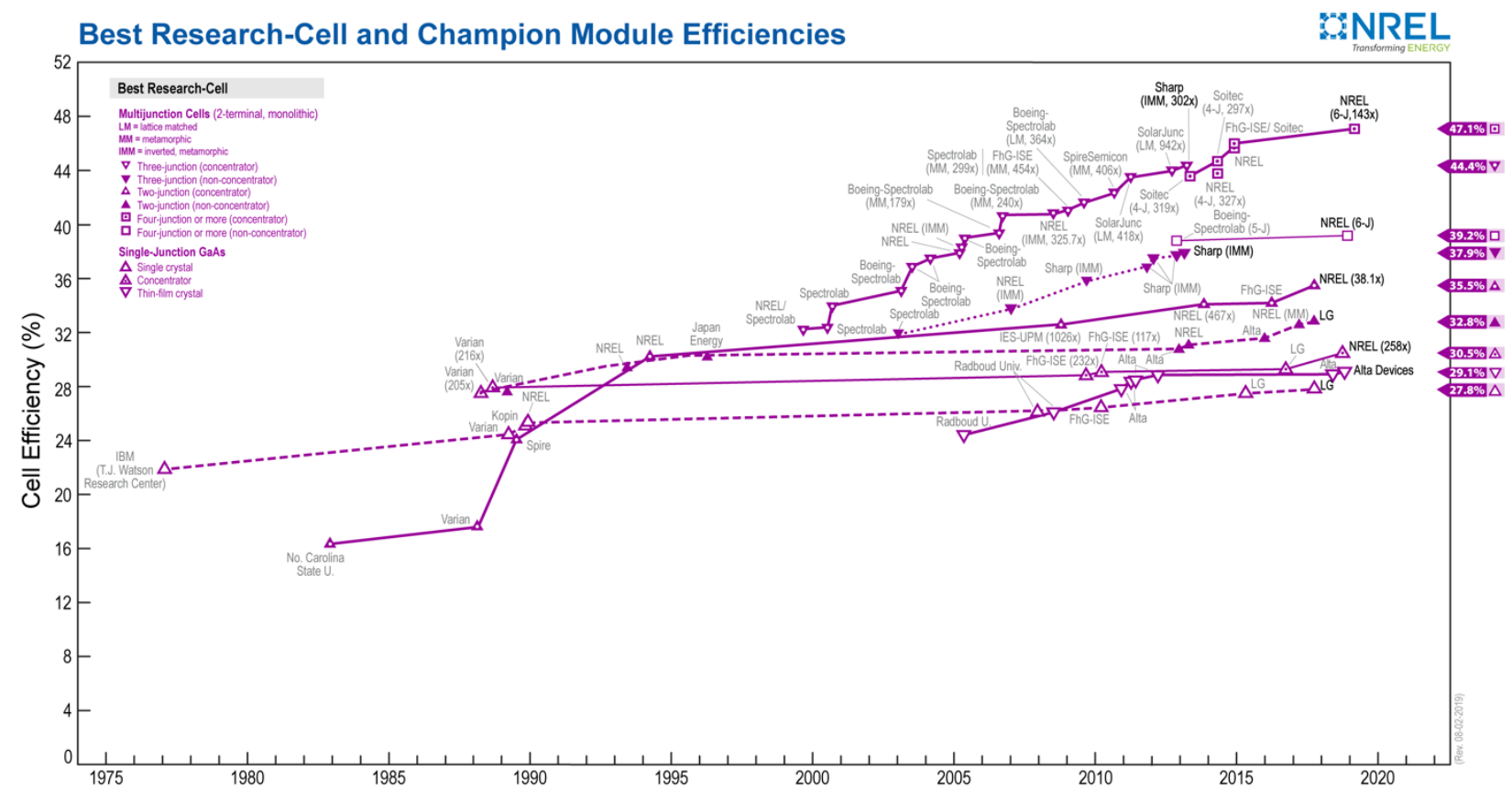

In the III-V industry, there is no standard device form factor. Customers in this market - mainly manufacturers of custom-designed satellite applications or aerospace projects - have substantial influence over design and quality requirements. However, most companies produce some version of a triple-junction (TJ) III-V device on a Ge substrate, including InGaP, InGaAs, and Ge junctions. Table 7 lists some of the leading III-V manufacturers. Typical 1-sun efficiencies are $25 \%-32 \%$ for commercially available TJ III-V devices. Doping levels, device thicknesses, and efficiencies vary by manufacturer. We benchmark a 33\%-efficient TJ device (Figure 30). We report on cell growth and fabrication only owing to the diversity of III-V applications and final module formats.

Table 7. Summary of III-V Companies

\begin{tabular}{|c|c|c|c|c|}
\hline Company & $\begin{array}{l}\text { Manufacturing } \\
\text { Locations }\end{array}$ & $\begin{array}{l}\text { Available Device } \\
\text { Efficiencies }\end{array}$ & $\begin{array}{c}\text { Thinnest } \\
\text { Devices } \\
(\mu \mathrm{m})\end{array}$ & $\begin{array}{c}\text { Lowest-Weight } \\
\text { Device } \\
\left(\mathrm{mg} / \mathrm{cm}^{2}\right)\end{array}$ \\
\hline SolAero & Albuquerque, NM & $32 \%$ AM0 & 50 & 28 \\
\hline Microlink Devices & Niles, IL & $31 \%$ AM1.5 & 40 & 35 \\
\hline Spectrolab & Sylmar, CA & $\begin{array}{l}32 \% \text { AM0, up to } 40 \% \\
\text { under concentration }\end{array}$ & 140 & 84 \\
\hline AZUR Space & $\begin{array}{l}\text { Heilbronn, } \\
\text { Germany }\end{array}$ & $\begin{array}{l}32 \% \text { AM0, up to } 44 \% \\
\text { under concentration }\end{array}$ & $110-190$ & 50 \\
\hline
\end{tabular}




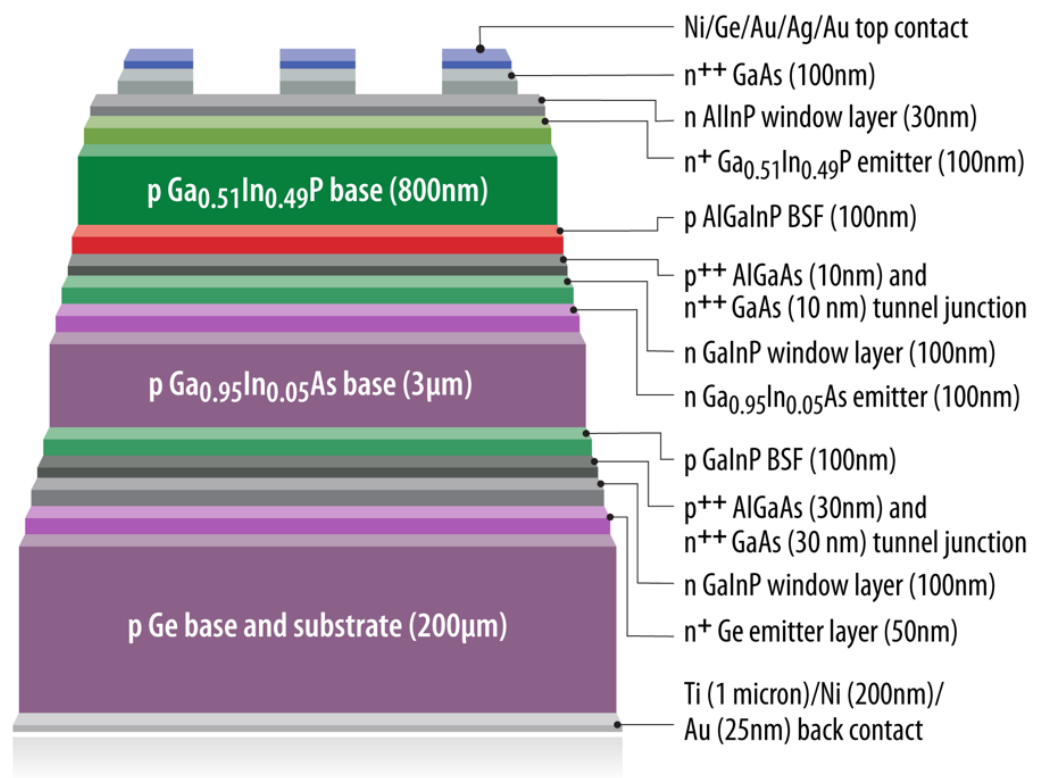

Figure 30. Ge-based TJ reference design

\subsubsection{Process Flows and Costs by Step}

Fabrication of III-V devices occurs through epitaxial deposition of PV material via MOVPE. The overall process flow is depicted in Figure 31 . The epitaxial layers are grown on semiconductor substrates in a high-temperature $\left(500-1,500^{\circ} \mathrm{C}\right)$ environment. The deposition occurs in a vacuum process chamber using a rotating graphite wafer platter to optimize uniform epitaxial growth rates and thickness across all processed wafers. Additional fabrication is completed with patterning lithography tools and metal deposition processes to produce antireflective coatings as well as gridlines and busbar connections. Costs by step are summarized in Table 8 and Figure 32 . The Ge wafer is the biggest cost contributor, followed by the MOVPE growth step.

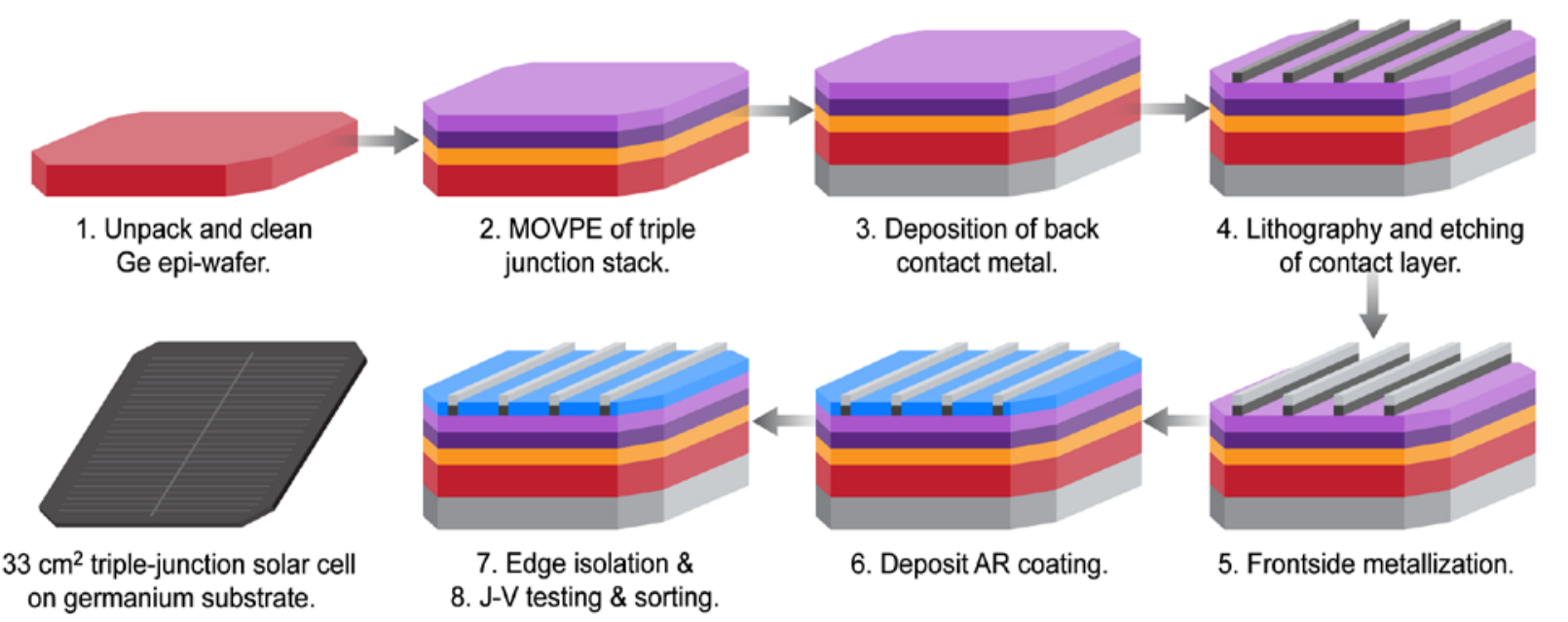

$\mathrm{AR}=$ antireflection

Figure 31. Process flow for Ge-based TJ cell 
Table 8. Overview of Inputs Used in NREL's III-V Cost Models

\begin{tabular}{|c|c|}
\hline \multicolumn{2}{|c|}{ Variable COGS Inputs for Cell Conversion } \\
\hline $\begin{array}{l}\text { Principal input } \\
\text { materials }\end{array}$ & $\begin{array}{l}\text { 6-in Ge substrate, trimethyl gallium (TMGa), trimethyl indium (TMIn), } \\
\text { TMAl, } \mathrm{AsH}_{3}, \mathrm{PH}_{3}, \mathrm{Ag}, \mathrm{Au} \text {. }\end{array}$ \\
\hline Labor & 0.15 direct employees per $\mathrm{kW}$ of annual production. \\
\hline Electricity & $12 \mathrm{kWh}$ per cell. \\
\hline Maintenance & Annual cost corresponding to $3 \%$ of the original investment in equipment. \\
\hline \multicolumn{2}{|c|}{ Fixed COGS Inputs for Cell Conversion } \\
\hline $\begin{array}{l}\text { Equipment CapEx } \\
\text { and depreciation }\end{array}$ & $\begin{array}{l}\text { Total equipment CapEx of } \$ 10.90 / \mathrm{W} \text { for standard baseline TJ III-V } \\
\text { processing line at } 200 \mathrm{~kW} / \text { capacity. } 7 \text {-year depreciation (straight line). }\end{array}$ \\
\hline $\begin{array}{l}\text { Facilities CapEx and } \\
\text { depreciation }\end{array}$ & $\begin{array}{l}\text { Total facility CapEx of } \$ 0.81 / \mathrm{W} \text { for new facility and building CapEx. } 20 \text { - } \\
\text { year depreciation (straight line). }\end{array}$ \\
\hline \multicolumn{2}{|c|}{ Remaining Fixed Operating Expenses } \\
\hline R\&D & $3 \%$ of revenues \\
\hline SG\&A & $9 \%$ of revenues \\
\hline
\end{tabular}

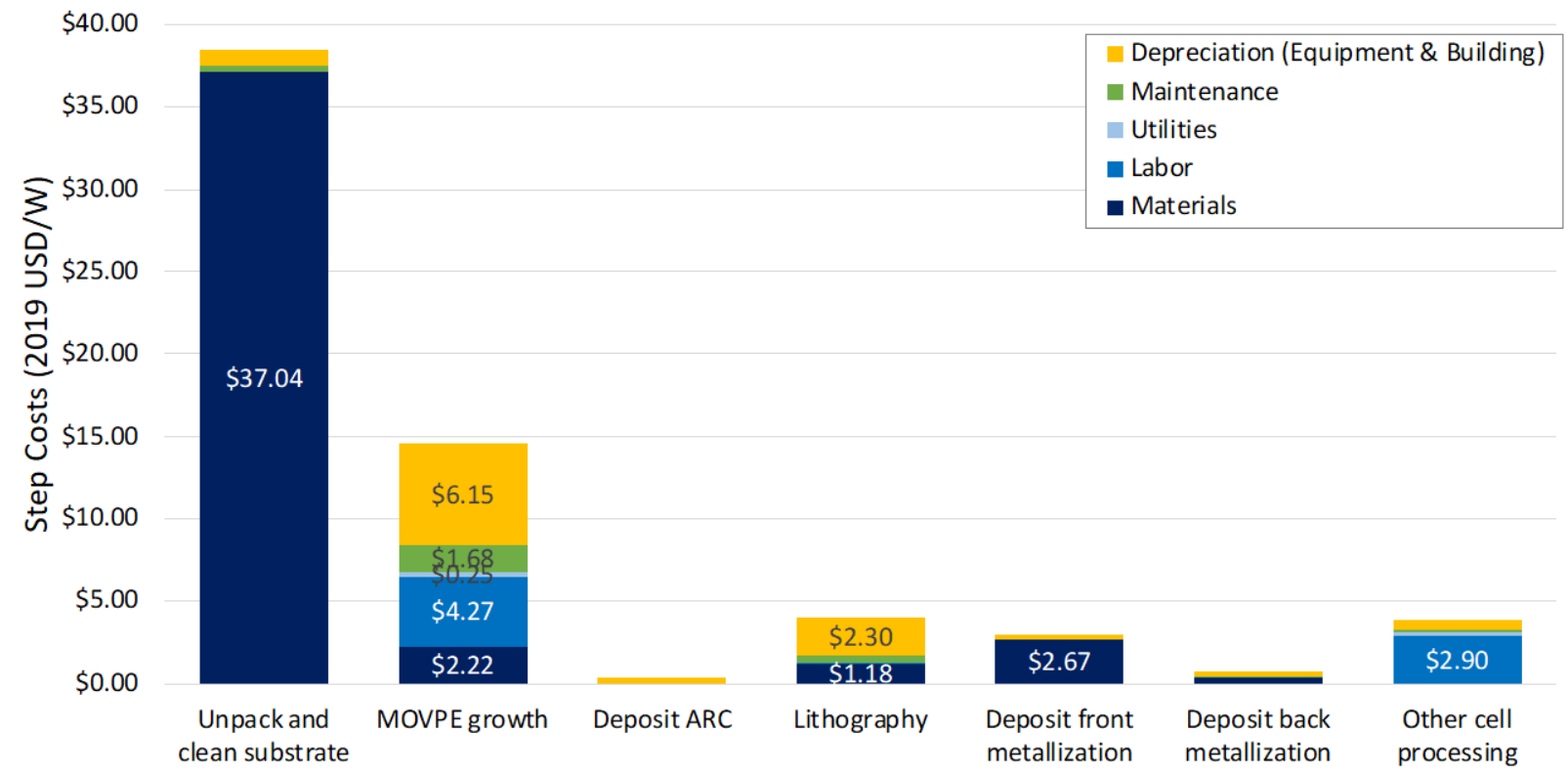

Figure 32. Step-by-step costs for MOVPE growth of TJ III-V cell on Ge substrate in the United States, 2020

\subsubsection{Benchmark Costs and Technology Roadmap}

Our 2020 benchmark MSP for TJ III-V PV devices on Ge is shown in Figure 33. This benchmark assumes a gross margin of 15\%; error bars show gross margins of $25 \%$ (high MSP) and 5\% (low MSP). 


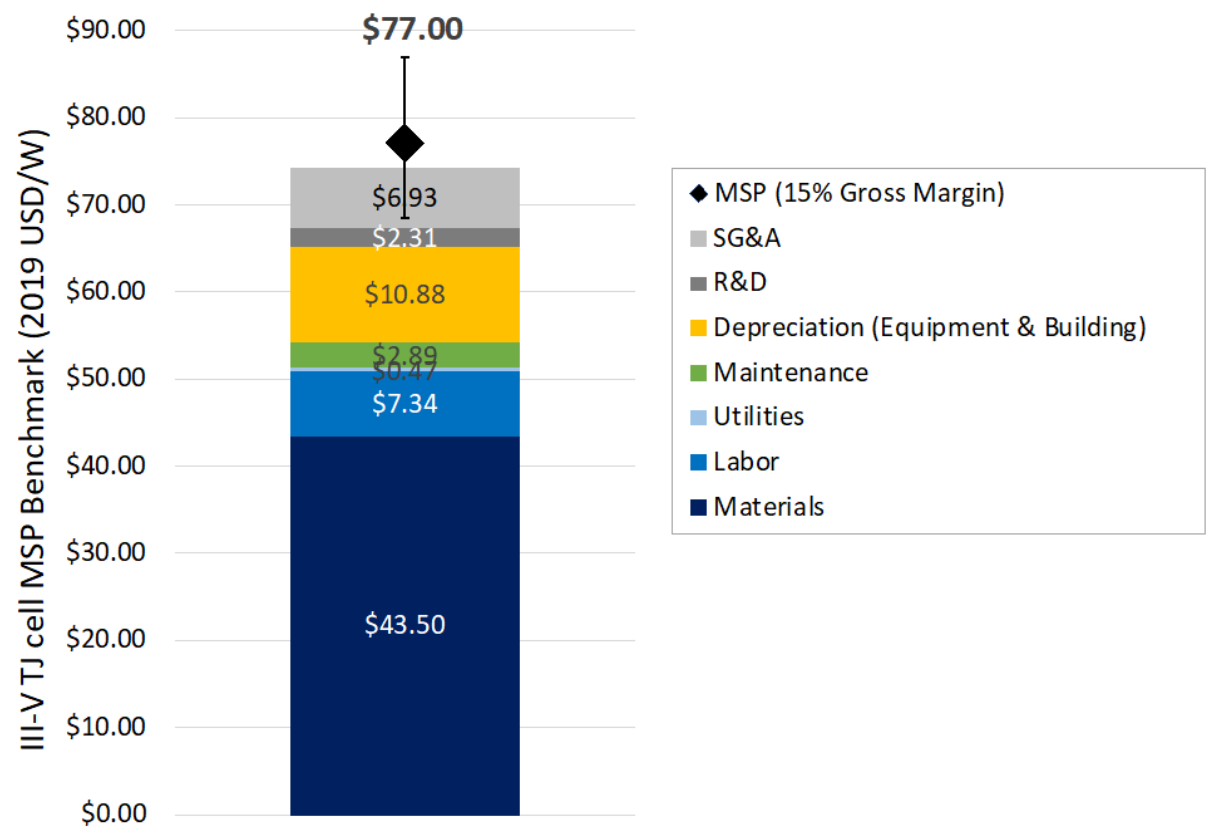

Figure 33. MSP benchmark for TJ III-V cell on Ge substrate, U.S. production, 2020

A cost-reduction roadmap for TJ III-V cells is shown in Figure 34. As shown in our model, substrate costs constitute more than $50 \%$ of total device costs, which has motivated research on processes to reuse the substrate to produce multiple PV cells. Epitaxial liftoff is the most common technique, in which a sacrificial release layer adjacent to the substrate is selectively dissolved (typically AlAs in hydrofluoric acid) (Ward, Remo et al. 2016). Because the MOVPE process is the second-largest cost driver, methods to reduce deposition costs are also prioritized. These include increased deposition rates, higher product yields, or lower material costs. Hydride vapor phase epitaxy (HVPE) is being investigated at NREL as a way to lower epitaxy material costs while increasing deposition rates (Horowitz, Remo et al. 2018). Metallization is another significant cost driver owing to the lithography process and the high cost of gold. Lower metallization costs could be achieved using electroplating or screen-printing techniques like those used for c-Si cells. Equipment scaling and general economies of scale are also possible pathways to reduce costs but are not estimated in the roadmap. 


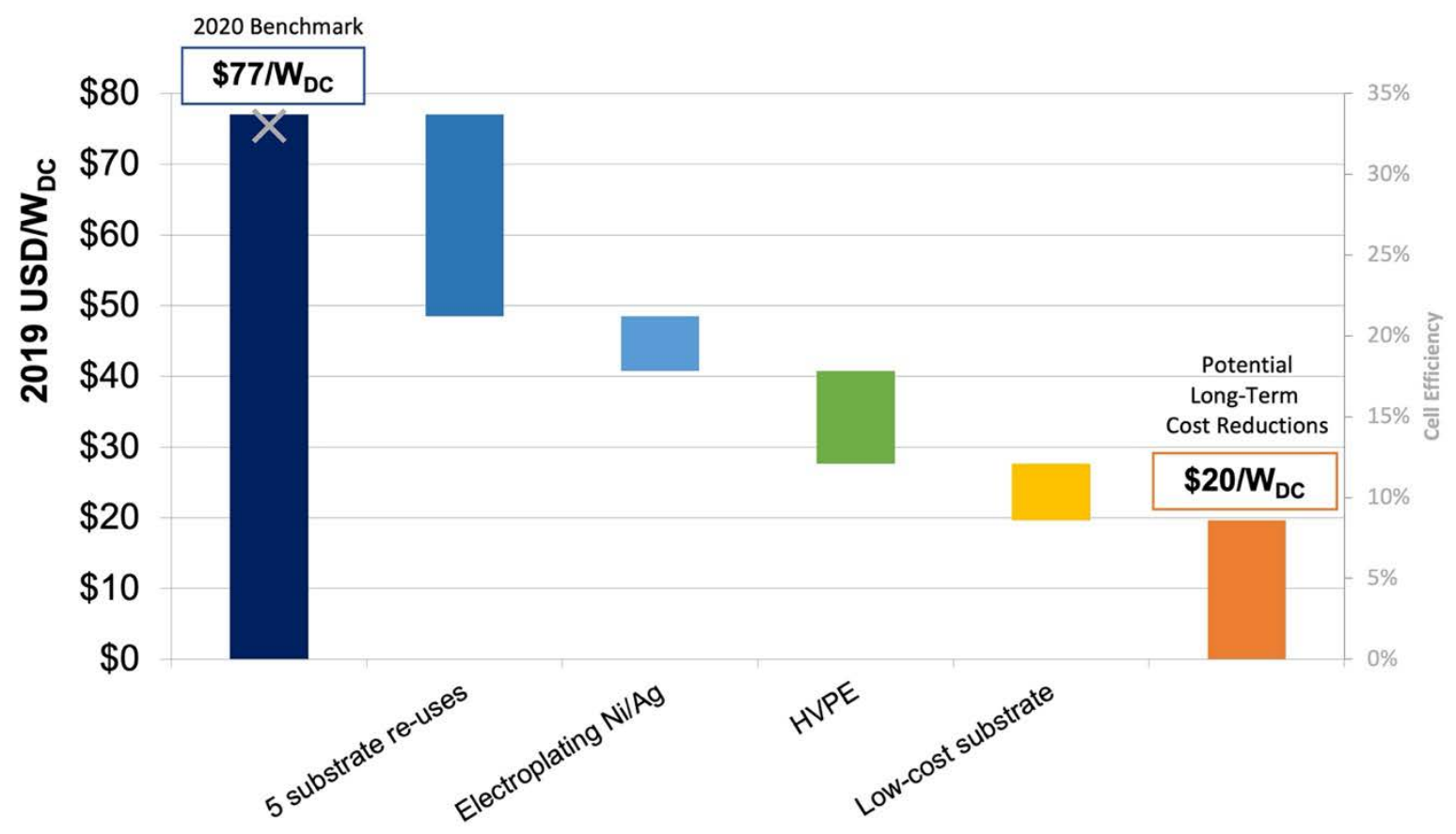

The TEF plot for 1-sun III-V PV systems is shown in Figure 35. Historical cost modeling results from NREL serve as a primary reference point for the 2010 cost and energy data (Woodhouse and Goodrich 2013, Horowitz, Woodhouse et al. 2015), while 2020 data reflect the cost model results from our current work. The 2030 data reflect the Stage 3 cost projection published in another NREL report, assuming module assembly similar to c-Si module assembly (Horowitz, Remo et al. 2018). Metrics such as power temperature coefficients and degradation rates over time were determined via discussion with experts at the 2020 NREL TEF Workshop (National Renewable Energy Laboratory 2020). III-Vs have exceptional performance in energy yield and service life, but costs would need to decline significantly to reach the 3 cents $/ \mathrm{kWh}$ LCOE target for 2030 .

III-Vs

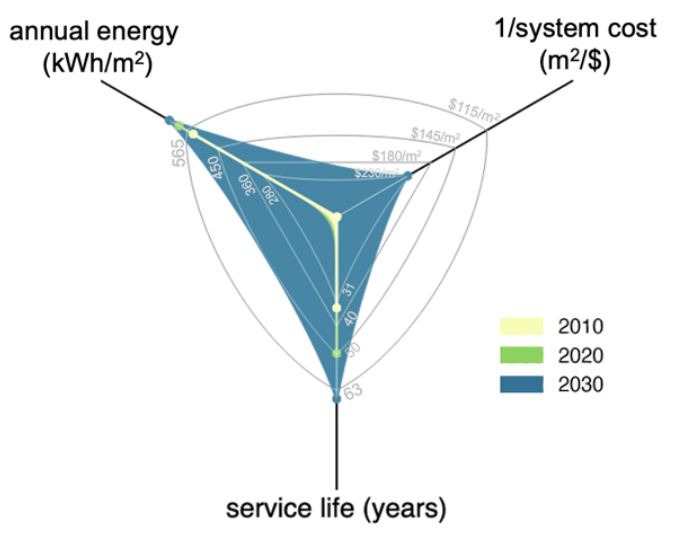

Figure 35. TEF plot for 1-sun III-V PV systems 


\subsection{Perovskites}

Various PV materials have been the subject of intense academic laboratory research. Some, such as copper zinc tin diselenide (CZTS) and organic PV, have garnered interest owing to their greater elemental earth abundance compared with CdTe or CIGS. Quantum dot cells exhibit multiple exciton generation, which may substantially increase current from PV devices (Nozik 2002). Dye-sensitized cells use a single layer of light-absorbing dye that is covalently bound to an optical scaffold and charge-transport matrix like $\mathrm{TiO}_{2}$ (Gratzel 2003).

Most recently, perovskites have emerged at the laboratory scale, offering new hope for a breakthrough material class for next-generation PV technologies and stimulating interest in new opportunities in commercialization and scale-up. In this section, we analyze perovskites in terms of technology manufacturing costs, efficiency progress, and reliability measurements.

Solution-processable perovskites offer potentially lower initial CapEx for manufacturing equipment and facilities, which is possible owing to the low temperature processing of the materials in perovskite devices (Table 9). These features open the processing window to spin coating, dip coating, spray pyrolysis, ink-jet printing, gravure coating, bar coating, and slot die coating. Perovskites also open the potential for new markets in which PV applications require flexible form factors and lower mass than traditional c-Si modules or glass-glass thin-film modules. The lower CapEx for R2R assumes the same efficiency and yield as S2S, although it remains to be seen whether this will hold for large-scale manufacturing. The R2R CapEx total presents a significant advantage over the typical CapEx for c-Si and CdTe as well, which are more comparable to the S2S magnitude around $\$ 0.25-\$ 0.30 / \mathrm{W}$.

Table 9. Overview of CapEx Differences for Rigid S2S vs. Flexible Roll-to-Roll (R2R) SingleJunction Perovskite Modules, Assuming the Same Efficiency (16\%)

\begin{tabular}{|c|c|c|c|}
\hline & Equipment and Facilities Investment & S2S (16\%) & R2R (16\%) \\
\hline \multirow{2}{*}{ Substrate } & Unload and clean front and back cover & $\$ 0.027-0.031 / \mathrm{W}$ & $\$ 0.027-0.031 / W$ \\
\hline & Sputter adhesion and diffusion barrier & $\$ 0.000 / \mathrm{W}$ & $\$ 0.014-0.018 / \mathrm{W}$ \\
\hline \multirow{5}{*}{ Solar Cell } & TCO sputtering & $\$ 0.013-0.017 / \mathrm{W}$ & $\$ 0.013-0.017 / \mathrm{W}$ \\
\hline & Active layer deposition and annealing & $\$ 0.022-0.026 / \mathrm{W}$ & $\$ 0.0024-0.0032 / \mathrm{W}$ \\
\hline & ETL and HTL deposition and annealing & $\$ 0.035-0.039 / \mathrm{W}$ & $\$ 0.0024-0.0032 / \mathrm{W}$ \\
\hline & Back contact & $\$ 0.075-0.079 / \mathrm{W}$ & $\$ 0.0024-0.0032 / \mathrm{W}$ \\
\hline & Monolithic integration & $\$ 0.039-0.043 / \mathrm{W}$ & $\$ 0.039-0.043 / \mathrm{W}$ \\
\hline \multirow{2}{*}{$\begin{array}{l}\text { Balance-of- } \\
\text { Module }\end{array}$} & Module layup and lamination & $\$ 0.037-0.041 / \mathrm{W}$ & $\$ 0.0024-0.0032 / \mathrm{W}$ \\
\hline & $\begin{array}{l}\text { Attach J-box, module testing and binning, and palletizing for } \\
\text { warehouse }\end{array}$ & $\$ 0.049-0.053 / \mathrm{W}$ & $\$ 0.049-0.053 / \mathrm{W}$ \\
\hline \multicolumn{2}{|c|}{$\begin{array}{l}\text { Total Capital Expenditure per Watt-Rated Annual Capacity } \\
\text { (Depreciation using } 5 \text { and } 20 \text { year straight-line for equipment and facilities) }\end{array}$} & $\begin{array}{l}\mathbf{\$ 0 . 3 0 - 0 . 3 3 / W} \\
(\$ 0.048-0.053 / \mathrm{W})\end{array}$ & $\begin{array}{l}\$ 0.15-0.17 / W \\
(\$ 0.024-0.027 / W)\end{array}$ \\
\hline
\end{tabular}

Perovskite bandgaps typically range from 1.2 to $2.3 \mathrm{eV}$, and the optical absorption profile can be tuned by managing the composition chemistry (Noh, Im et al. 2013). The absorption coefficient of the perovskite material most common in academic research, methylammonium lead iodide $\left(\mathrm{CH}_{3} \mathrm{NH}_{3} \mathrm{PbI}_{3}\right)$, allows for very thin layers $(200-500 \mathrm{~nm})$ that absorb across the entire visible 
spectrum (Batmunkh, Zhong et al. 2020). A high absorption coefficient across a customizable optical profile means that perovskite materials can be used efficiently in single-junction devices or multijunction architectures in which optimal efficiency requires precisely tuned absorption in both the top and bottom cells. Charge-carrier lengths in the $\mu \mathrm{m}$ range-well beyond the absorption depth of the material - also enable high efficiencies in perovskite thin-film PV devices (Saliba, Matsui et al. 2016). Most recently, control of bulk (Yang, Park et al. 2017) and surface (Jiang, Zhao et al. 2019) recombination in perovskite devices has led to efficiency improvements. Perovskite cells have experienced rapid efficiency gains through all these technology advancements and many more that have not been mentioned. Champion cell efficiencies have surged from near 14\% when they first appeared on the NREL efficiency chart in 2013 (Burschka, Pellet et al. 2013) to the most recent 25.2\% record established in 2020. The record efficiencies of perovskites and other emerging PV technologies over time are shown in Figure 36.

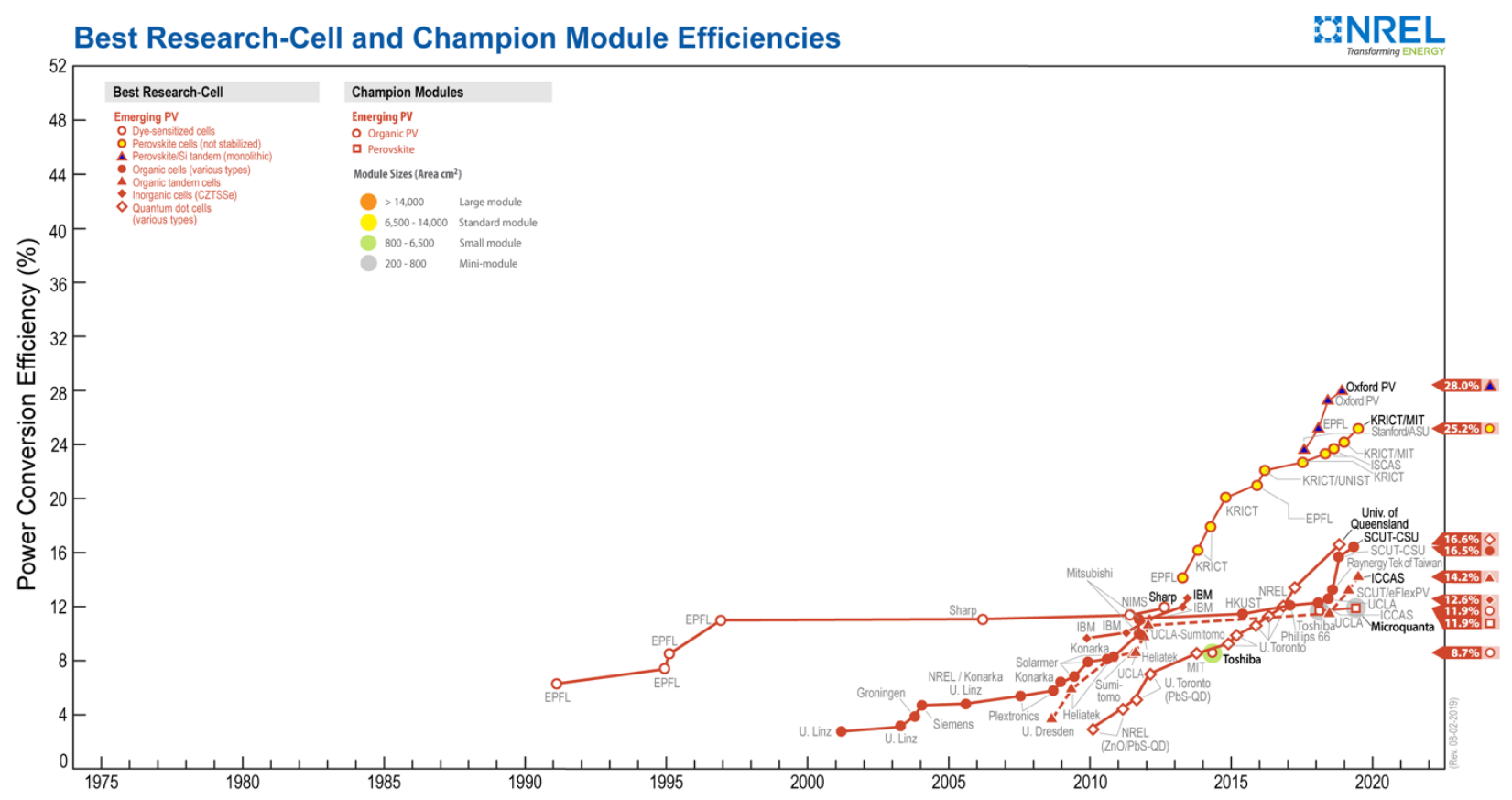

Figure 36. Efficiency progress for early-stage PV technologies including perovskites

For our benchmark analysis, we consider generic perovskite absorbers in the reference design shown in Figure 37. The bandgap of $\mathrm{MAPbI}_{3}$, the most common single-junction absorber, is around 1.5-1.6 eV, with a light-absorption spectrum up to a wavelength of $800 \mathrm{~nm}$ (Jeon, Noh et al. 2015). However, there are stability and efficiency advantages for different cation and anion mixtures, and the cost differential between perovskite compositions is well within the margins of uncertainty in this model. 


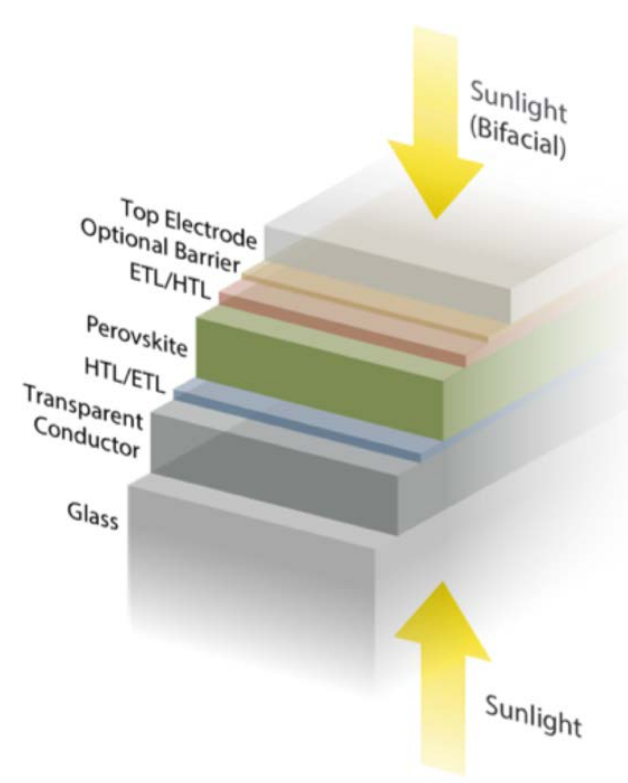

Figure 37. Single-junction perovskite reference design

\subsubsection{Process Flows and Costs by Step}

The process flow for manufacturing an S2S single-junction perovskite module is shown in Figure 38, and the costs by step for this process are shown in Figure 39. These costs are not currently representative of commercial production and are instead serving as a hypothetical estimate of costs given the current scale of perovskite research, material, and equipment availability. The process flow for a dual-junction perovskite cell would have two additional steps for depositing a recombination layer and another sequence of ETL/HTL, perovskite ink, and HTL/ETL deposition for the second cell in the stack.

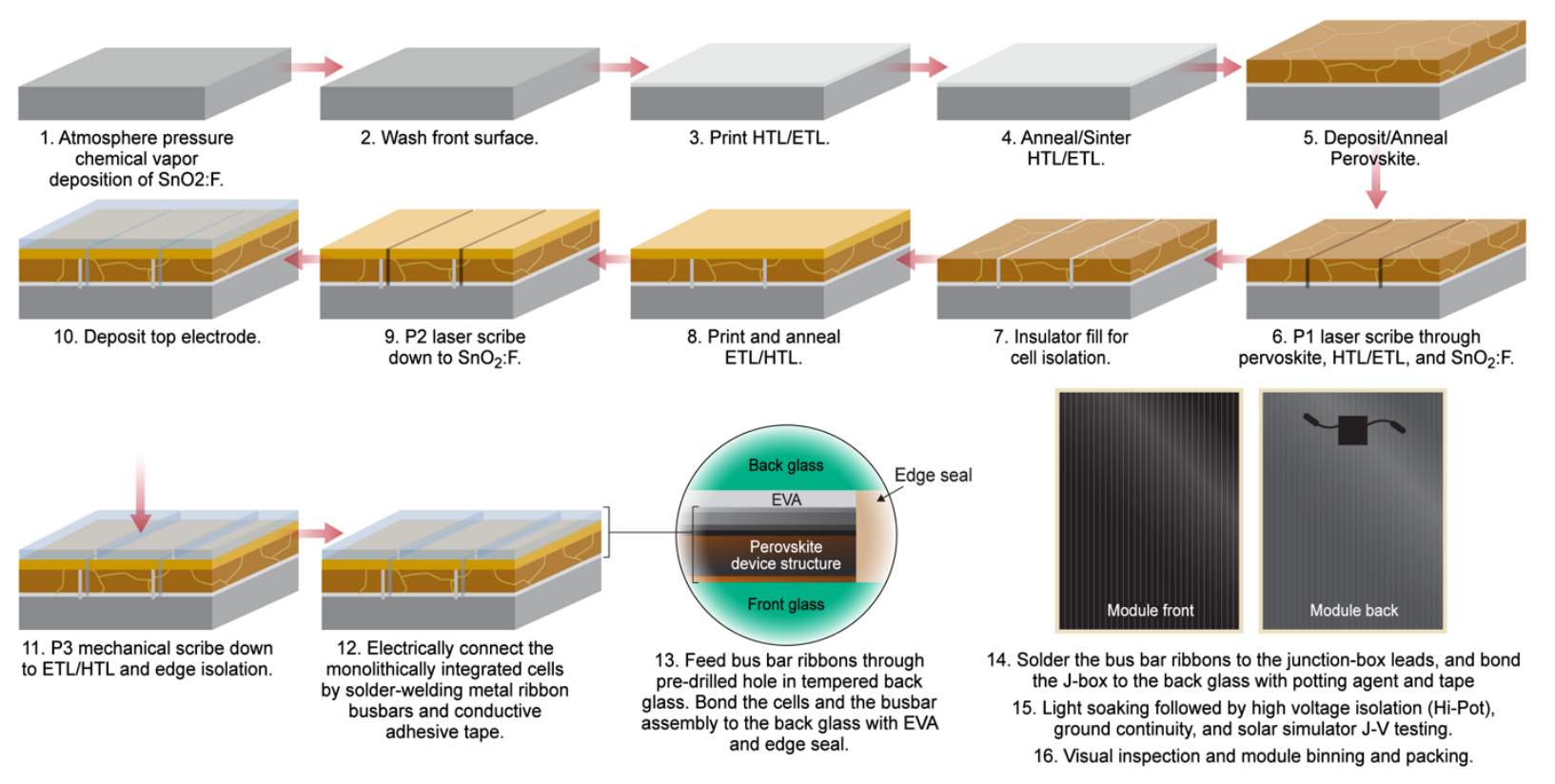

Figure 38. Process flow for S2S single-junction perovskite module 


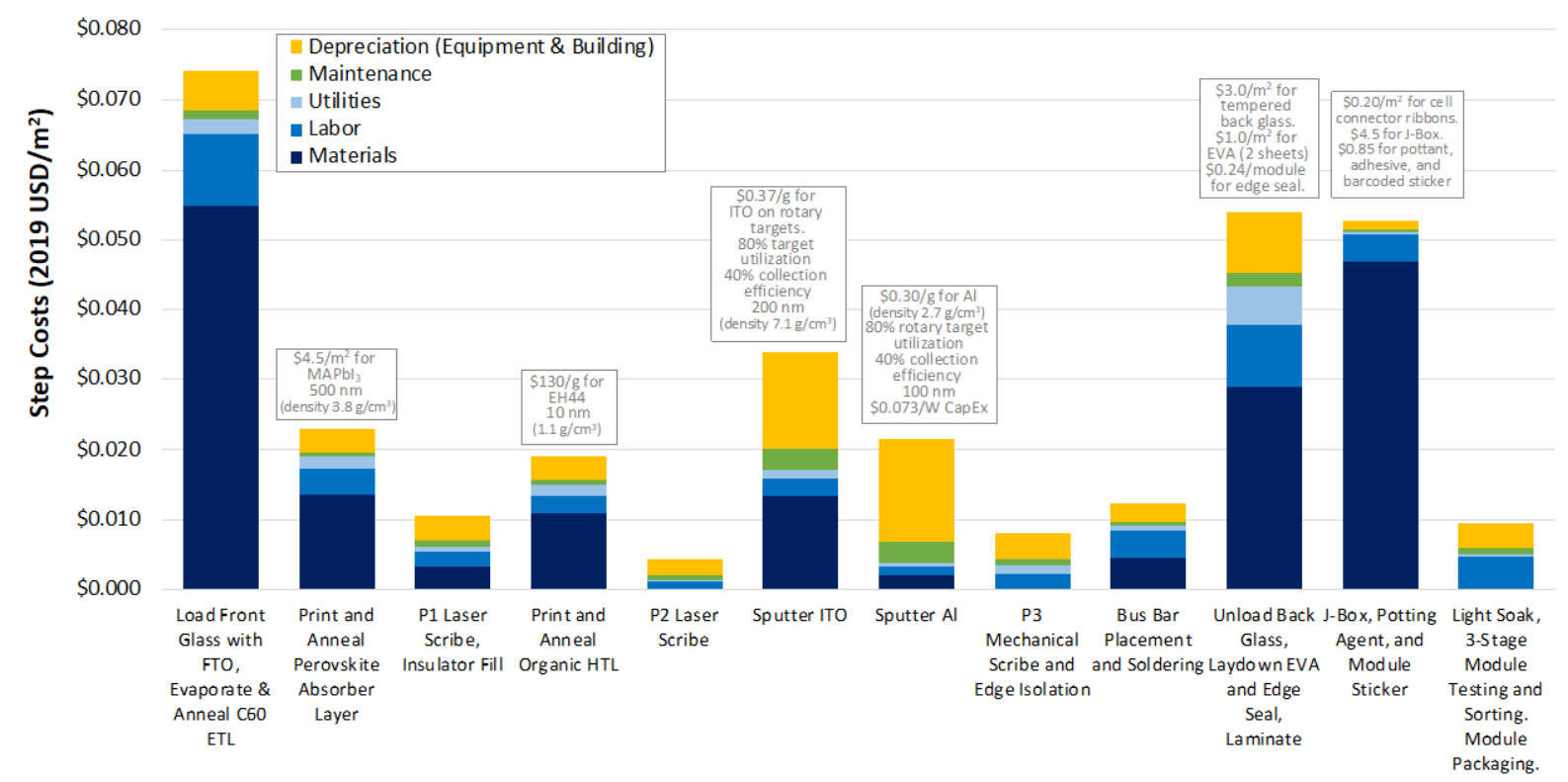

$\mathrm{C}_{60}=$ carbon-60, EH44 = 9-(2-ethylhexyl)- $N, N, N, N$-tetrakis(4-methoxyphenyl)-9H-carbazole-2,7-diamine, $\mathrm{FTO}=$ fluorine-doped tin oxide.

Figure 39. Step-by-step costs for S2S single-junction perovskite module manufacturing in the United States, 2020 (est.)

The process flow for producing a perovskite-on-Si tandem cell is shown in Figure 40, which then proceeds through a typical module assembly process such as in Figure 7. Our cost model assumes a two-terminal configuration with an n-type SHJ cell as the bottom cell and a singlejunction perovskite as the top cell. We assume a near-term module efficiency of $28 \%$ based on NREL-certified results from Oxford PV which exceed this value (Case, Beaumont et al. 2019, Osborne 2020). This process assumes a PCBM interlayer, although a $\mathrm{SnO}_{2} / \mathrm{C}_{60}$ stack is an alternative option. The costs by step for the perovskite-on-Si tandem cell and subsequent module assembly are shown in Figure 41. PCBM costs may be higher than anticipated because of low evaporation yield due to polymerization during the deposition process.

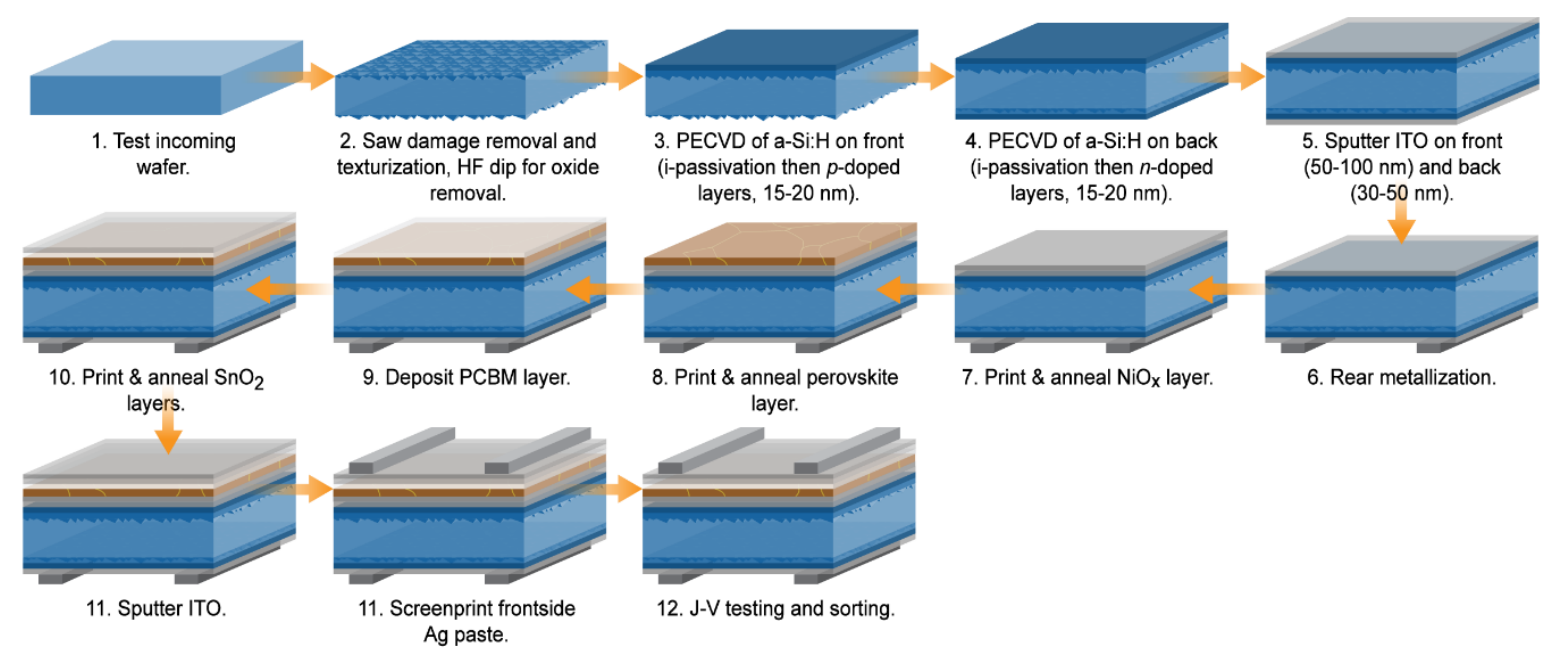

Figure 40. Process flow for perovskite-on-Si tandem cell 


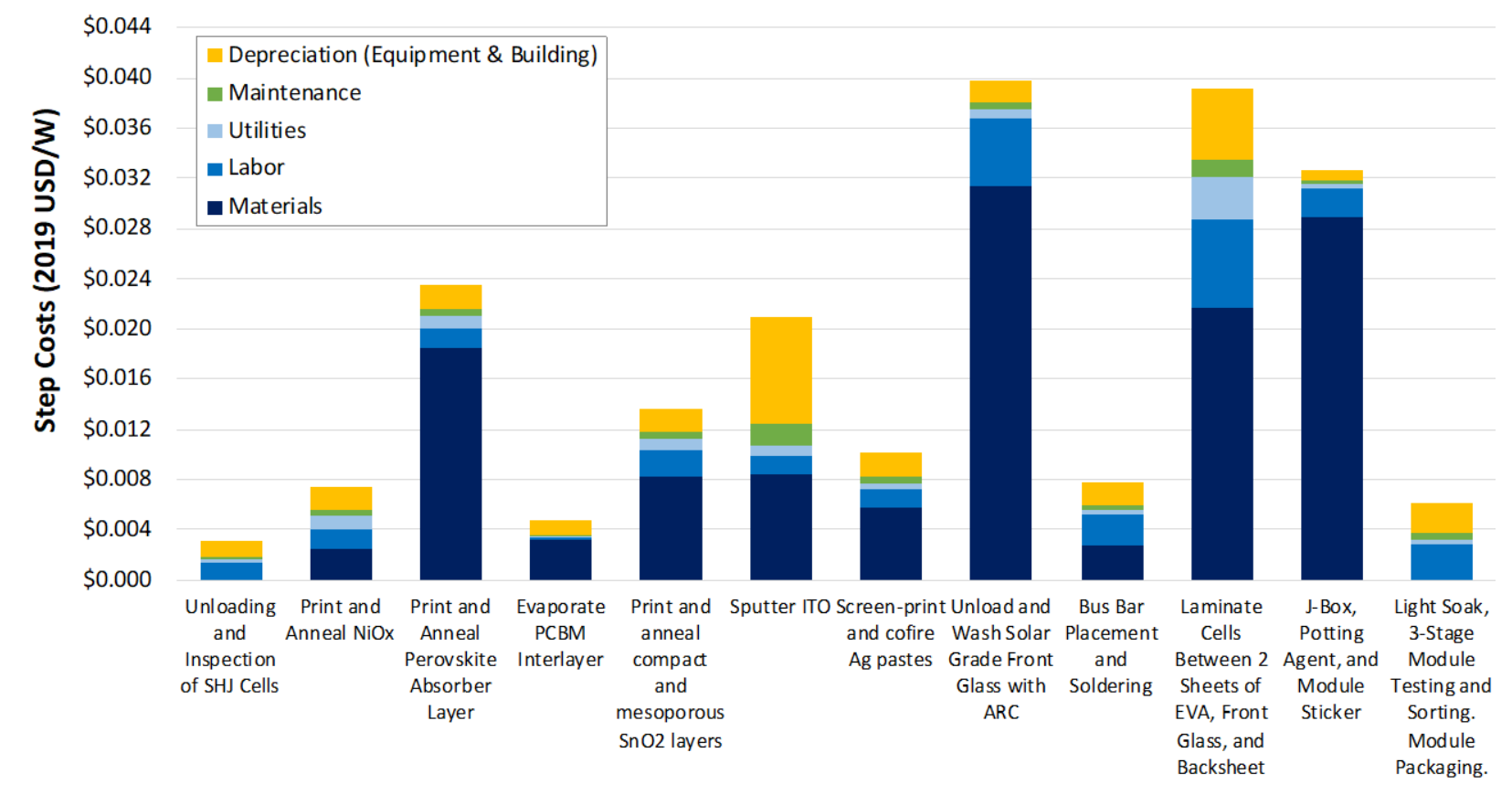

PCBM = methanofullerene phenyl-C61-butyric-acid-methyl-ester.

Figure 41. Step-by-step costs for perovskite-on-Si tandem module manufacturing in the United States, 2020 (est.)

Table 10 summarizes the inputs used to obtain the cost model results in this section, for the allperovskite architecture and the perovskite-on-Si tandem. 
Table 10. Overview of Inputs Used in NREL's Single-Junction Perovskite and Perovskite-on-Si Tandem Cost Models

\begin{tabular}{|c|c|}
\hline \multicolumn{2}{|c|}{ Product Details (in addition to reference designs) } \\
\hline Cell & SHJ architecture for c-Si bottom cell. \\
\hline Module & $\begin{array}{l}0.72 \mathrm{~m}^{2} \text { for single-junction perovskite module, } 1.97 \mathrm{~m}^{2} \text { for } 72 \text {-cell } \\
\text { perovskite-on-Si tandem module. }\end{array}$ \\
\hline \multicolumn{2}{|c|}{ Variable COGS Inputs for Cell Conversion } \\
\hline $\begin{array}{l}\text { Principal input } \\
\text { materials }\end{array}$ & $\begin{array}{l}\text { A generic perovskite ink is assumed. Several options (including } \mathrm{MAPbl}_{3} \text {, } \\
\mathrm{FAPbl}_{3}, \mathrm{CsPb}_{3} \text {, and "kitchen sink" options) were evaluated, and costs } \\
\text { were determined to have a maximum variation of } 30 \% \text {. }\end{array}$ \\
\hline Labor & 1 direct employee per MW of annual production. \\
\hline Electricity & Total $27-28 \mathrm{kWh}$ per module. \\
\hline Maintenance & Annual cost corresponding to $4 \%$ of the original investment in equipment. \\
\hline \multicolumn{2}{|c|}{ Fixed COGS Inputs for Cell Conversion } \\
\hline $\begin{array}{l}\text { Equipment CapEx } \\
\text { and depreciation }\end{array}$ & $\begin{array}{l}\text { Total capacity: } 5.2 \text { million modules/year for perovskite single-junction } \\
\text { modules ( } 2.0 \mathrm{GW} \text { at } 16 \% \text { efficiency), } 2.0 \mathrm{GW} \text { perovskite-on-Si tandems } \\
\text { ( } 28 \% \text { efficiency). See Table } 9 \text { for discussion of CapEx. Assumes } 5 \text {-year } \\
\text { straight-line depreciation. }\end{array}$ \\
\hline $\begin{array}{l}\text { Facilities CapEx and } \\
\text { depreciation }\end{array}$ & $\begin{array}{l}\text { See Table } 9 \text { for discussion of CapEx. Assumes 20-year depreciation } \\
\text { (straight line). }\end{array}$ \\
\hline \multicolumn{2}{|c|}{ Remaining Fixed Operating Expenses } \\
\hline R\&D & $3 \%$ of value-added revenues. \\
\hline SG\&A & $9 \%$ of value-added revenues. \\
\hline
\end{tabular}

\subsubsection{Projected Costs and Technology Roadmap}

Because perovskites are not yet commercially available, we estimate S2S single-junction costs at a small production scale and provide a roadmap for future commercial development in Figure 42. The estimated costs for 2020 consider a smaller-format module; significant cost savings are expected by using a larger-format module. Improving single-junction efficiency to $22 \%$ and maintaining this performance in the larger-format module could achieve a price of $\$ 0.21 / \mathrm{W}$ by 2025. Developing an all-perovskite two-junction module with an efficiency of $30 \%$ could achieve prices as low as $\$ 0.18 / \mathrm{W}$ in the long term. However, these potential cost reductions would only be possible if the performance and durability of perovskites can be improved without significant increases in expenses such as materials or processing, which is not certain at this stage of technology development.

Finally, the estimated costs and MSP for perovskite-on-Si tandem module production at small scale are shown in Figure 43. The MSP estimate assumes a gross margin of 15\%; error bars show gross margins of 25\% (high MSP) and 5\% (low MSP). This technology could benefit from progress along the perovskite and c-Si roadmaps presented in Figure 42 and Figure 13. 


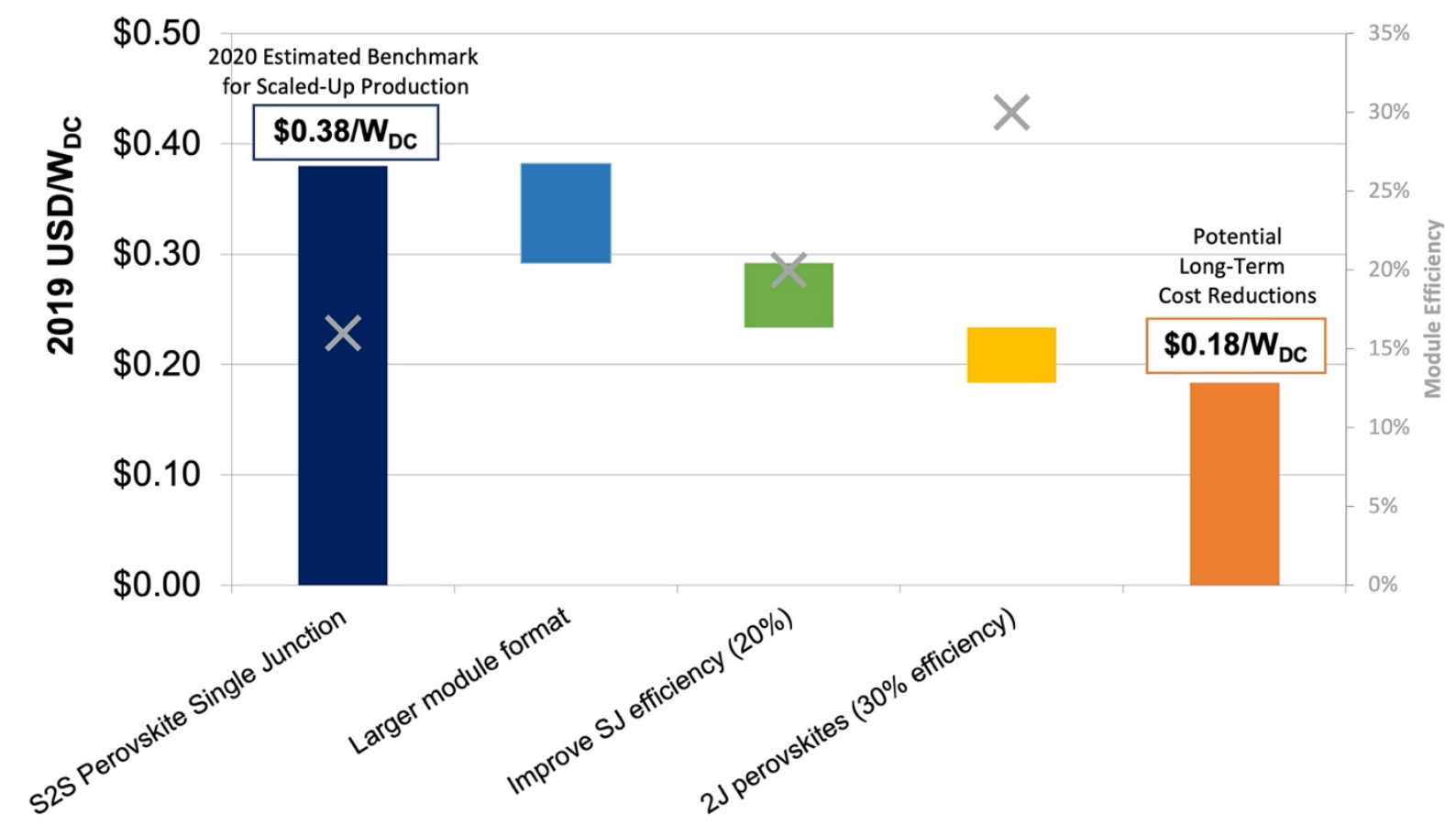

Costs assume greater than $1 \mathrm{GW}$ of annual production. $2 \mathrm{~J}=$ two-junction, $\mathrm{SJ}=$ single-junction.

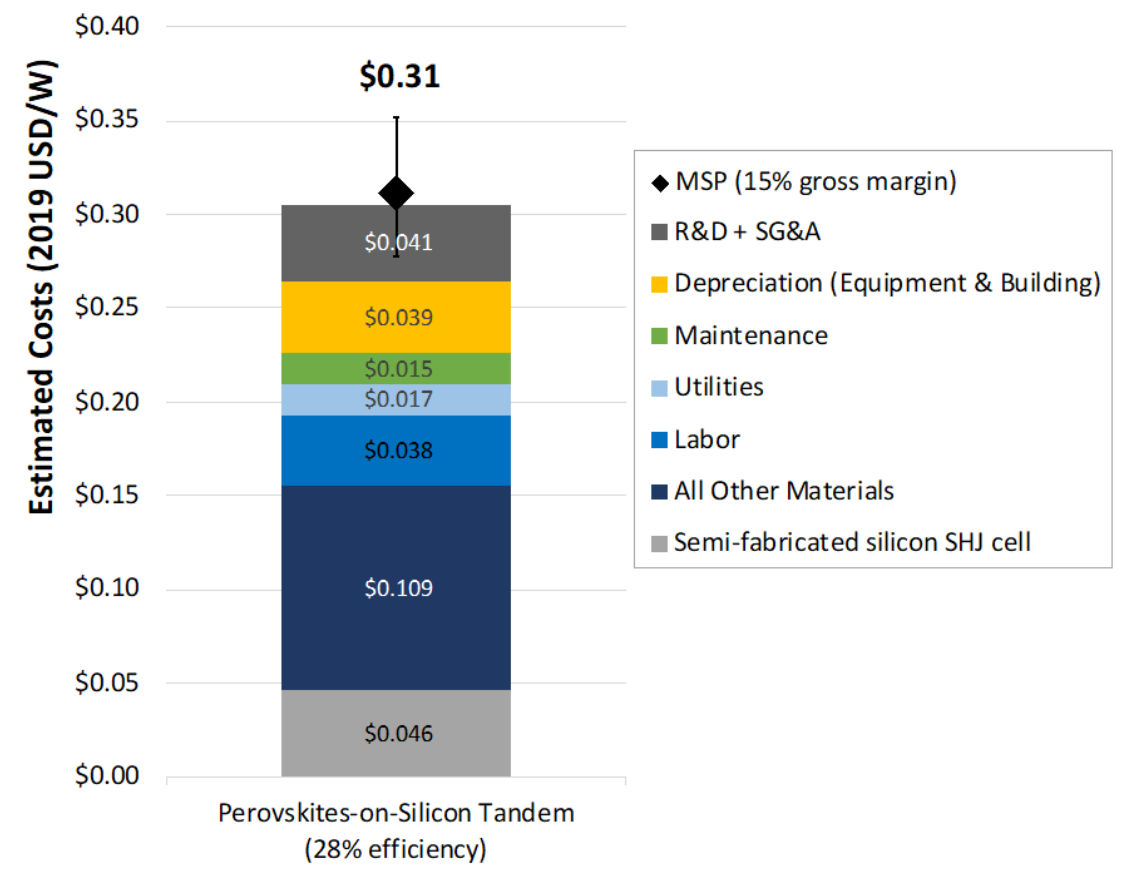

Figure 43. Estimated costs and MSP for perovskite-on-Si tandem module production in the United States 
The TEF plot for perovskites is shown in Figure 44. Because perovskite PV research is relatively new, historical data are based on early laboratory efficiencies and high costs associated with laboratory-scale production. The 2020 and 2030 data reflect the cost model results from our current work. Metrics such as power temperature coefficients and degradation rates over time were determined via discussion with experts at the 2020 NREL TEF Workshop (National Renewable Energy Laboratory 2020). Given the high degradation rates currently associated with perovskites, cost is the primary metric that must be developed to reach the 2030 LCOE target of 3 cents $/ \mathrm{kWh}$. However, given the early stage of this technology, the degradation rates achievable by perovskites over the long term are still unknown.

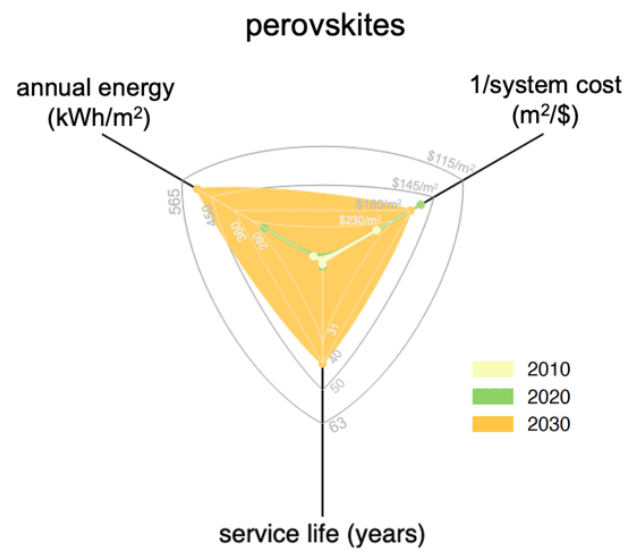

Figure 44. TEF plot for perovskite PV systems

\section{Conclusions}

We benchmark module MSPs in this report via bottom-up manufacturing cost analysis. Figure 45 summarizes our MSP benchmarks for established PV technologies in mass production. Technologies based on c-Si dominate the current PV market, and their MSPs are the lowest; the figure only shows the MSP for monocrystalline monofacial PERC modules, but benchmark MSPs are similar $(\$ 0.25-\$ 0.27 / \mathrm{W})$ across the c-Si technologies we analyze. CdTe modules have a slightly higher MSP $(\$ 0.28 / \mathrm{W})$, and the CIGS MSP represents a larger step up $(\$ 0.48 / \mathrm{W})$, largely owing to higher labor and equipment/facility costs.

We provide technology roadmaps to additional MSP reductions for these PV technologies, summarized in Figure 46. The MSPs for c-Si and CdTe modules stay similar to each other over the short and long term, while the CIGS premium shrinks but remains significant. 


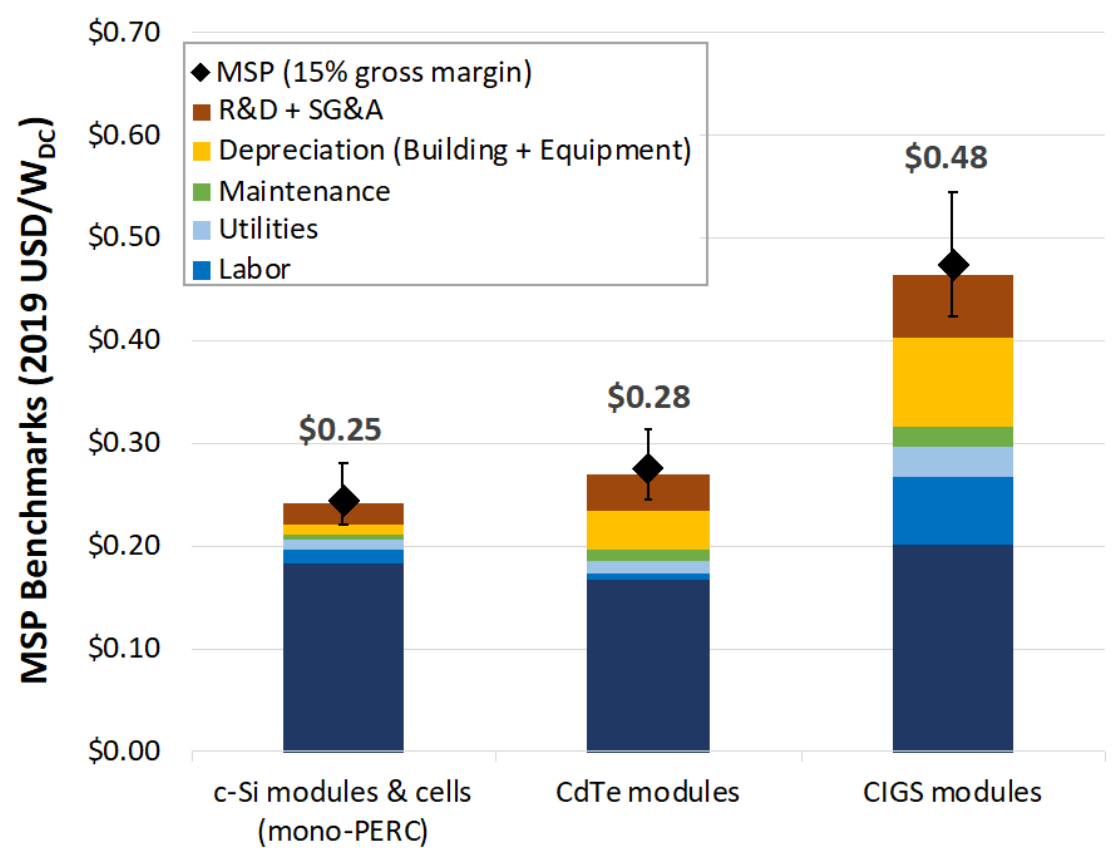

Figure 45. Summary of MSPs for established PV technologies, 2020

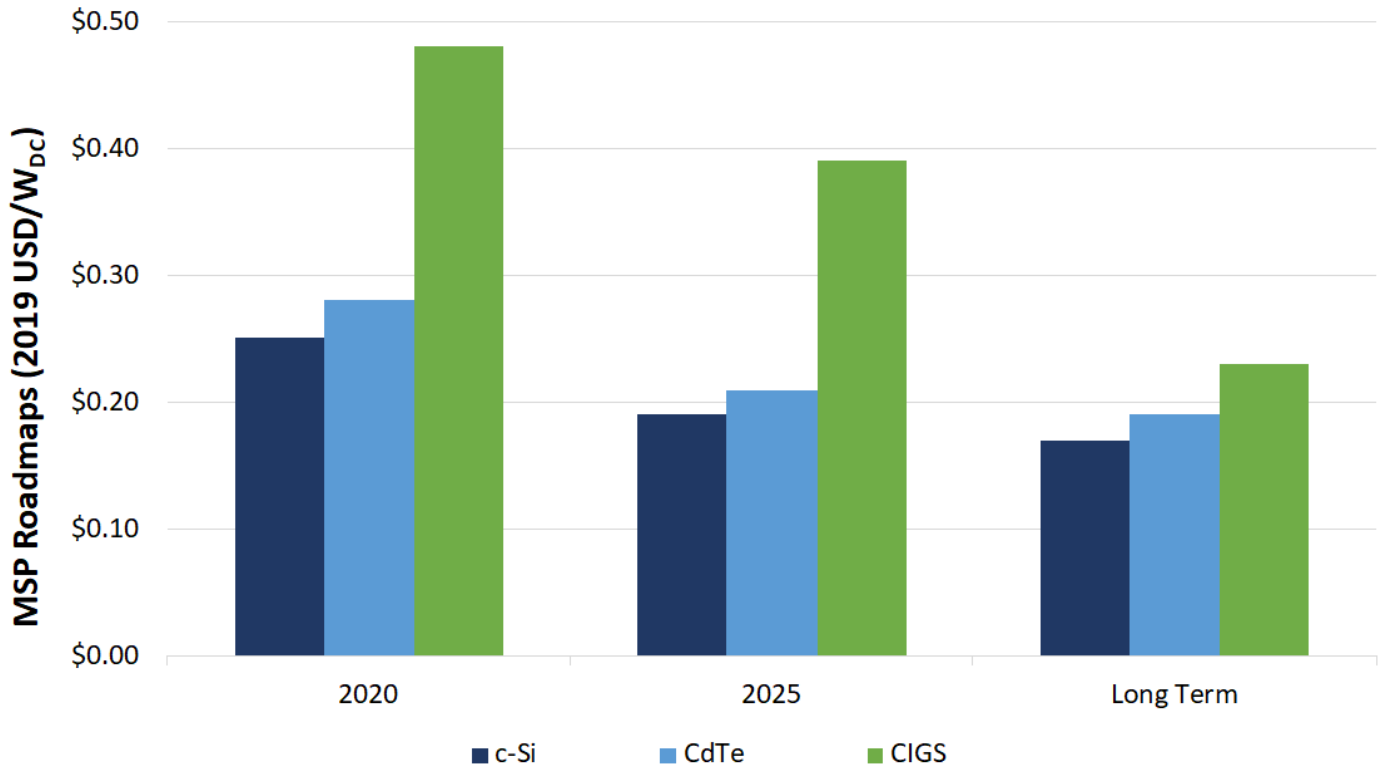

Figure 46. Summary of projected module MSPs for established PV technologies, assuming $15 \%$ gross margin

We also separately consider III-V and perovskite PV technologies, which are currently in smallscale or pilot production. This report contains our first technoeconomic assessment of perovskite PV as well. As shown in Figure 47, the III-V MSP benchmark is two orders of magnitude higher $(\$ 77 / \mathrm{W})$ than the benchmarks for established technologies, and to date such high prices have kept III-V technology in niche markets including space and terrestrial concentrator applications. This challenge is reflected in the III-V roadmap, in which several potential cost reductions still result in a long-term projection of $\$ 20 / \mathrm{W}$, two orders of magnitude higher than the long-term 
MSPs of the other technologies. As shown in Section 4.2.2, the single-junction S2S perovskite module MSP estimated at small production scale is $\$ 0.38 / \mathrm{W}$, with potential cost reductions over the long term achieving $\$ 0.18 / \mathrm{W}$ if performance is able to be improved without incurring additional costs. Perovskites can also be combined with other PV technologies in multijunction configurations. We estimate a $2020 \mathrm{MSP}$ of $\$ 0.31 / \mathrm{W}$ for small-scale perovskite-on-Si tandem module production, and this technology could benefit from progress along both the perovskite and c-Si roadmaps.
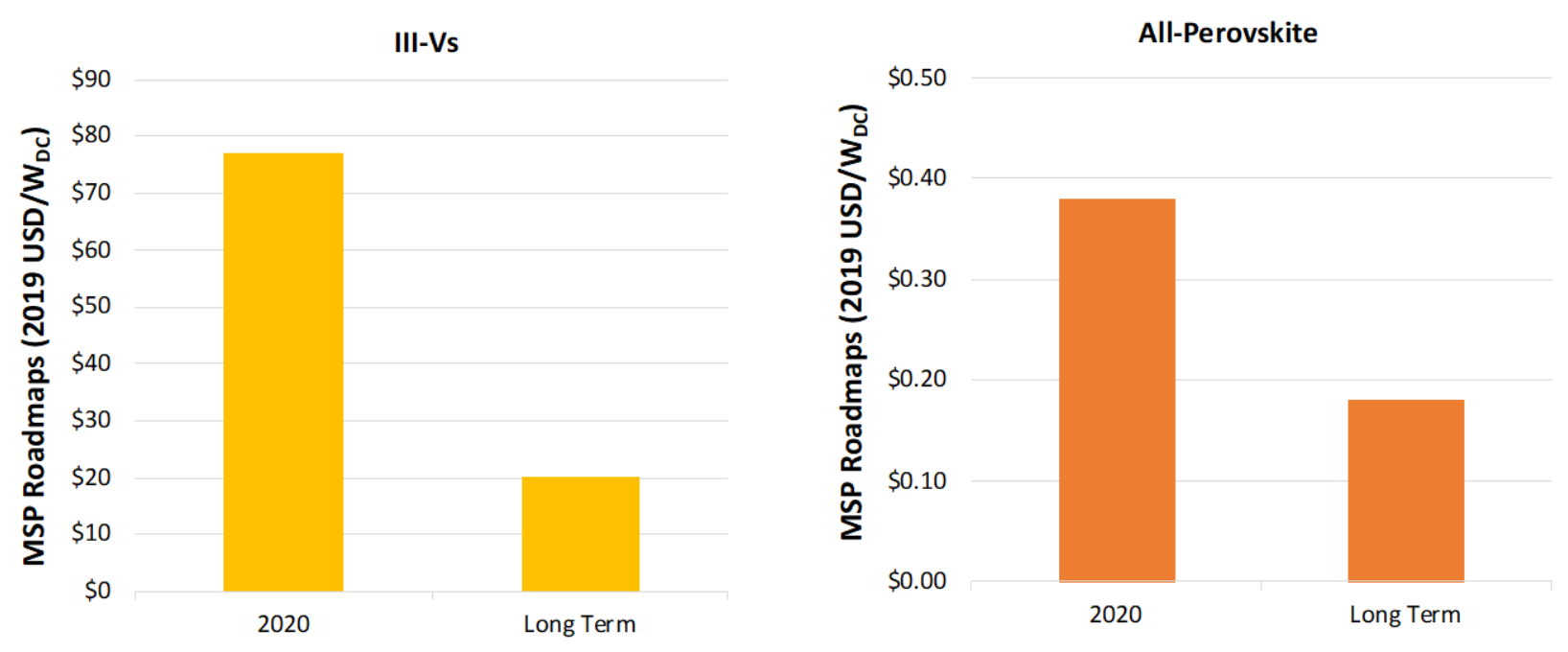

Figure 47. Estimated MSPs for III-V and all-perovskite PV technologies

The costs captured in our MSP results represent only some of the factors that determine actual module selling prices. Cost reductions related to production scale-up (economies of scale) and the accumulation of manufacturing experience (learning by doing) are important, but they are not estimated in our cost-reduction roadmaps. Other important module price drivers not captured in our bottom-up analysis include global supply and demand fluctuations, domestic policies related to PV deployment and manufacturing, trade policies, and corporate strategies. Comparing our bottom-up module MSP results with module market prices helps illuminate these other drivers.

Finally, this report developed a technology evolution framework to analyze additional drivers of LCOE reductions, including system cost—which is heavily influenced by module price-as well as service life and annual energy yield. These results highlight technology-specific challenges and opportunities related to achieving the 3 cents $/ \mathrm{kWh}$ LCOE target by 2030. CdTe and c-Si technologies are likely to achieve higher efficiencies by 2030, which increases the annual energy yield and alleviates the reductions in system cost needed to reach the 2030 LCOE target. In contrast, CIGS systems require the larger cost reductions owing to limits on annual energy yield caused by the lower long-term efficiency projection for CIGS. Similarly, both III-V and perovskite technologies require large system cost reductions to achieve the 2030 LCOE target: the III-Vs because their exceptional energy yield and service life potential cannot fully offset their extremely high current system cost, and perovskites because they currently have the shortest service life among all technologies. 


\section{References}

Batmunkh, M., Y. L. Zhong and H. Zhao (2020). "Recent advances in Perovskites-Based Building-Integrated Photovoltaics." Advanced Materials 32: 2000631.

Burschka, J., N. Pellet, S.-J. Moon, R. Humphry-Baker, P. Gao, M. K. Nazeeruddin and M. Gratzel (2013). "Sequential deposition as a route to high performance Perovskite-sensitized solar cells." Nature 499: 316-320.

Case, C., N. Beaumont and D. Kirk (2019). "Industrial Insights into Perovskite Photovoltaics." ACS Energy Letters 4(11): 2760-2762.

Compaan, A. D. (2006). "Photovoltaics: Clean Power for the 21st Century." Solar Energy Materials and Solar Cells 90: 2170-2180.

DOE (2012). "SunShot Vision Study." https://www1.eere.energy.gov/solar/pdfs/47927.pdf.

Feldman, D. J. and R. M. Margolis (2020). Q1/Q2 2020 Solar Industry Update, National Renewable Energy Lab.(NREL), Golden, CO (United States).

Feldman, D. J., E. O'Shaughnessy and R. M. Margolis (2020). Q3/Q4 2019 Solar Industry Update, National Renewable Energy Lab.(NREL), Golden, CO (United States).

Feldman, D. J., V. Ramasamy, R. Fu, A. Ramdas, J. Desai and R. M. Margolis (2021). US Solar Photovoltaic System Cost Benchmark: Q1 2020, National Renewable Energy Lab (NREL), Golden, CO (United States).

Feldman, D. J., V. Ramasamy, R. Fu, A. Ramdas, J. Desai and R. M. Margolis (Forthcoming). US Solar Photovoltaic System Cost Benchmark: Q1 2020, National Renewable Energy Lab (NREL), Golden, CO (United States).

Fu, R., D. Feldman and R. Margolis (2018). "U.S. Solar Photovoltaic System Cost Benchmark: Q1 2018." NREL Technical Report Available online: https://www.nrel.gov/docs/fy190sti/72399.pdf.

Goodrich, A., P. Hacke, Q. Wang, B. Sopori, R. Margolis, T. James and M. Woodhouse (2013). "A wafer-based monocrystalline silicon photovoltaics roadmap: utilizing known technical improvement opportunities for further reductions in manufacturing costs." Solar Energy Materials and Solar Cells 114: 110-135.

Goodrich, A., T. James and M. Woodhouse (2011). Solar PV Manufacturing Cost Analysis: U.S. Competitiveness in a Global Industry. https://www.nrel.gov/docs/fy12osti/53938.pdf, NREL Golden, Colorado.

Gratzel, M. (2003). "Dye-sensitized solar cells." J Photochemistry and Photobiology 4(2): 145153. 
Green, M. A., E. D. Dunlop, D. H. Levi, J. Hohl-Ebinger, M. Yoshita and A. Ho-Baillie (2019). "Solar cell efficiency tables." Progress in Photovoltaics 27: 565-575.

Horowitz, K., M. Woodhouse, H. Lee and G. Smestad (2015). Bottom-Up Cost Analysis of a High Concentration PV Module; NREL (National Renewable Energy Laboratory), NREL (National Renewable Energy Laboratory (NREL), Golden, CO (United States)).

Horowitz, K. A., T. W. Remo, B. Smith and A. J. Ptak (2018). A Techno-Economic Analysis and Cost Reduction Roadmap for III-V Solar Cells. United States.

Horowitz, K. A. W., R. Fu and M. Woodhouse (2016). "An analysis of glass-glass CIGS manufacturing costs." Solar Energy Materials and Solar Cells 154: 1-10.

ITRPV Working Group (2012). "International Technology Roadmap for Photovoltaics Results 2011."

ITRPV Working Group (2019). International Technology Roadmap for Photovoltaic ( ITRPV ) 2018 Results. https://itrpv.vdma.org/, SEMI, Berlin, Germany.

ITRPV Working Group (2020). International Technology Roadmap for Photovoltaic ( ITRPV ) 2019 Results. https://itrpv.vdma.org/, SEMI, Berlin, Germany.

Jeon, N. J., J. H. Noh, W. S. Yang, Y. C. Kim, S. Ryu, J. Seo and S. I. Seok (2015).

"Compositional engineering of Perovskite materials for high performance solar cells." Nature 517: $476-481$.

Jiang, Q., Y. Zhao, X. Zhang, X. Yang, Y. Chen, Z. Chu, Q. Ye, X. Li, Z. Yin and J. You (2019). "Surface passivation of Perovskite film for efficient solar cells." Nature Photonics 13: 460-466.

Jones-Albertus, R., D. Feldman, R. Fu, K. Horowitz and M. Woodhouse (2016). "Technology Advances Needed for Photovoltaics to Achieve Widespread Grid Price Parity." Progress in Photovoltaics Available online at: http://energy.gov/eere/sunshot/downloads/technologyadvances-needed-photovoltaics-achieve-widespread-grid-price-parity(DOI: 10.1002/pip.2755).

Kanevce, A., M. O. Reese, T. Barnes, S. Jensen and W. Metzger (2017). "The roles of carrier concentration and interface, bulk, and grain-boundary recombination for $25 \%$ efficient CdTe solar cells." Journal of Applied Physics 121(21): 214506.

Kinsey, G. S. (2015). "Spectrum sensitivity, energy yield, and revenue prediction of PV modules." IEEE Journal of Photovoltaics 5(1): 258-262.

LME (London Metal Exchange) (2020). LME Silver. https://www.lme.com/Metals/Preciousmetals/LME-Silver.

Mints, P. (April 2019). "SPV Market Research: Phototovoltaic manufacturer shipments, capacities, price, and revenues 2018/2019." 
Mishima, T., M. Taguchi, H. Sakata and E. Maruyama (2011). "Development status of highefficiency HIT solar cells." Solar Energy Materials and Solar Cells 95(1): 18-21.

Moseley, J., P. Rale, S. Collin, E. Colegrove, H. Guthrey, D. Kuciauskas, H. Moutinho, M. AlJassim and W. K. Metzger (2018). "Luminescence methodology to determine grain-boundary, grain-interior, and surface recombination in thin-film solar cells." Journal of Applied Physics 124(11): 113104.

National Renewable Energy Laboratory (2020). Technology Evolution Framework Workshop. Golden, CO.

Noh, J. H., S. H. Im, J. H. Heo, T. N. Mandal and S. I. Seok (2013). "Chemical management for colorful, efficient, and stable inorganic-organic hybrid nanostructured solar cells." Nano Letters 13: $1764-1769$.

Nozik, A. J. (2002). "Quantum dot solar cells." Physica E 14(1): 115-120.

Osborne, M. (2019) "Eurotron MWT cell equipment in mass production at Sunport Power's facility in China." PVTech.

Osborne, M. (2020) "Oxford PV pushes tandem SHJ/perovskite cell conversion efficiency to record 29.52\%." PVTech.

Saliba, M., T. Matsui, J.-Y. Seo, K. Domanski, J.-P. Correa-Baena, M. K. Nazeeruddin, S. M. Zakeeruddin, W. Tress, A. Abate, A. Hagfeldt and M. Gratzel (2016). "Cesium-containing triple cation Perovskite solar cells: Improved stability, reproducibility and high efficiency." Energy and Environmental Science 9: 1989-1997.

Siefer, G. and A. W. Bett (2014). "Analysis of temperature coefficients for III-V multi-junction concentrator cells." Progress in Photovoltaics: Research and Applications 22(5): 515-524.

Silverman, T. J., M. G. Deceglie and K. A. Horowitz. (2018). "NREL Comparative PV LCOE Calculator." from pvlcoe.nrel.gov.

SPV Market Research (2019). Photovoltaic Manufacturer Capacity, Shipments, Price \& Revenues 2018/2019. http://www.spvmarketresearch.com/.

SPV Market Research (2020). Photovoltaic Manufacturer Capacity, Shipments, Price \& Revenues 2019/2020. http://www.spvmarketresearch.com/.

Topič, M., R. M. Geisthardt and J. R. Sites (2015). "Performance Limits and Status of SingleJunction Solar Cells With Emphasis on CIGS." IEEE Journal of Photovoltaics 5(1): 360-365.

Tous, L., M. Aleman, R. Russell, E. Cornagliotti, P. Choulat, A. Uruena, S. Singh, J. John, F. Duerinckx, J. Poortmans and R. Mertens (2015). "Evaluation of advanced p-PERL and n-PERT large area silicon solar cells with $20.5 \%$ energy conversion efficiencies." Progress in Photovoltaics: Research and Applications 23(5): 660-670. 


\section{U.S. Department of Energy (2012) "SunShot Vision Study."}

Ward, J. S., T. Remo, K. Horowitz, M. Woodhouse, B. Sopori, K. VanSant and P. Basore (2016). "Techno-economic analysis of three different substrate removal and reuse strategies for III-V solar cells." Progress in Photovoltaics: Research and Applications 24(9): 1284-1292.

Wolf, S. D., A. Descoeudres, Z. C. Holman and C. Ballif (2012). "High-efficiency Silicon Heterojunction Solar Cells: A Review." Green 2(1): 7.

Woodhouse, M. and A. Goodrich (2013). A manufacturing cost analysis relevant to single-and dual-junction photovoltaic cells fabricated with III-Vs and III-Vs grown on Czochralski silicon, National Renewable Energy Laboratory.

Woodhouse, M., A. Goodrich, R. Margolis, T. James, R. Dhere, T. Gessert, T. Barnes, R. Eggert and D. Albin (2013). "Perspectives on the Pathways for Cadmium Telluride Photovoltaic Module Manufacturers to Address Expected Increases in the Price for Tellurium." Solar Energy Materials and Solar Cells 115: 199-212.

Woodhouse, M., K. Horowitz, R. Fu, D. Chung, D. Feldman, T. Remo and R. Margolis (2016). On the path to sunshot: The role of advancements in photovoltaics efficiency, reliability, and costs. National Renewable Energy Laboratory.

Woodhouse, M., R. Jones-Albertus, D. Feldman, R. Fu, K. Horowitz, D. Chung, D. Jordan and S. Kurtz (2016). "On the Path to SunShot: The Role of Advancements in Photovoltaics Efficiency, Reliability, and Costs " U.S. Department of Energy Available online: http://energy.gov/eere/sunshot/downloads/role-advancements-photovoltaic-efficiencyreliability-and-costs.

Woodhouse, M., B. Marion, R. Fu, D. Feldman, B. Smith, C. Deline, J. Stein, A. Mayer, S. Huang and R. Margolis (2019). "Considerations for utilizing bifacial photovoltaic technologies based upon their impact to project financial metrics." NREL Technical Report In Preparation.

Woodhouse, M., B. Smith, A. Ramdas and R. Margolis (2019). Crystalline Silicon Photovoltaic Module Manufacturing Costs and Sustainable Pricing: 1H 2018 Benchmark and Cost Reduction Roadmap. National Renewable Energy Laboratory, https://www.nrel.gov/docs/fy19osti/72134.pdf.

Yang, W. S., B.-W. Park, E. H. Jung, N. J. Jeon, Y. C. Kim, D. U. Lee, S. S. Shin, J. Seo, E. K. Kim, J. H. Noh and S. I. Seok (2017). "Iodide management in formamdinium-lead-halide-based Perovskite layers for efficient solar cells." Science 356: 1376-1379. 


\section{Appendix}

Table A-1. Input Data for TEF Plots

\begin{tabular}{|c|c|c|c|c|c|c|c|c|c|c|}
\hline & & $\begin{array}{l}\text { Mono } \\
\text { PERC }\end{array}$ & $\begin{array}{l}\text { Bifacial } \\
\text { PERC }\end{array}$ & si-IBC & $\begin{array}{l}\text { PERT/ } \\
\text { PERL }\end{array}$ & SHJ & CdTe & CIGS & III-Vs & Perovskites \\
\hline \multirow{6}{*}{2010} & $\begin{array}{l}\text { Module price } \\
(\$ / W)\end{array}$ & $\$ 2.00$ & $\$ 3.00$ & $\$ 2.00$ & $\$ 3.00$ & $\$ 2.00$ & $\$ 1.25$ & $\$ 0.80$ & $\$ 200$ & $\$ 11.20$ \\
\hline & System cost $(\$ / W)$ & $\$ 2.76$ & $\$ 3.75$ & $\$ 2.68$ & $\$ 3.74$ & $\$ 2.72$ & $\$ 2.20$ & $\$ 1.84$ & $\$ 200$ & $\$ 15.50$ \\
\hline & Efficiency at STC & $18 \%$ & $18 \%$ & $22 \%$ & $20 \%$ & $20 \%$ & $13 \%$ & $12 \%$ & $30 \%$ & $2 \%$ \\
\hline & $\begin{array}{l}\text { Power } \\
\text { temperature } \\
\text { coefficient }\left(\mathrm{K}^{-1}\right)\end{array}$ & $-0.35 \%$ & $-0.25 \%$ & $-0.30 \%$ & $-0.40 \%$ & $-0.25 \%$ & $-0.30 \%$ & $-0.40 \%$ & $-0.20 \%$ & $-0.20 \%$ \\
\hline & Efficiency at $50^{\circ} \mathrm{C}$ & $16.4 \%$ & $16.9 \%$ & $20.4 \%$ & $18.0 \%$ & $18.8 \%$ & $12.0 \%$ & $10.8 \%$ & $28.5 \%$ & $1.9 \%$ \\
\hline & $\begin{array}{l}\text { Degradation rate } \\
\text { (\% per year) }\end{array}$ & $1 \%$ & $1 \%$ & $0.7 \%$ & $1 \%$ & $1 \%$ & $0.7 \%$ & $0.7 \%$ & $0.6 \%$ & $80 \%$ \\
\hline \multirow{6}{*}{2020} & $\begin{array}{l}\text { Module price } \\
(\$ / W)\end{array}$ & $\$ 0.25$ & $\$ 0.26$ & $\$ 0.27$ & $\$ 0.25$ & $\$ 0.27$ & $\$ 0.28$ & $\$ 0.48$ & $\$ 100$ & $\$ 0.38$ \\
\hline & System cost $(\$ / W)$ & $\$ 0.97$ & $\$ 0.94$ & $\$ 0.91$ & $\$ 0.94$ & $\$ 0.92$ & $\$ 1.05$ & $\$ 1.32$ & $\$ 101$ & $\$ 1.31$ \\
\hline & Efficiency at STC & $20.5 \%$ & $22 \%$ & $25 \%$ & $22 \%$ & $24 \%$ & $18 \%$ & $16 \%$ & $33 \%$ & $13 \%$ \\
\hline & $\begin{array}{l}\text { Power } \\
\text { temperature } \\
\text { coefficient }\left(\mathrm{K}^{-1}\right) \\
\end{array}$ & $-0.35 \%$ & $-0.25 \%$ & $-0.30 \%$ & $-0.40 \%$ & $-0.25 \%$ & $-0.30 \%$ & $-0.40 \%$ & $-0.20 \%$ & $-0.20 \%$ \\
\hline & Efficiency at $50^{\circ} \mathrm{C}$ & $18.7 \%$ & $20.6 \%$ & $23.1 \%$ & $19.8 \%$ & $22.5 \%$ & $16.7 \%$ & $14.4 \%$ & $31.4 \%$ & $12.4 \%$ \\
\hline & $\begin{array}{l}\text { Degradation rate } \\
\text { (\% per year) }\end{array}$ & $0.5 \%$ & $0.7 \%$ & $0.5 \%$ & $0.7 \%$ & $0.7 \%$ & $0.45 \%$ & $0.45 \%$ & $0.40 \%$ & $10.0 \%$ \\
\hline \multirow{6}{*}{2030} & $\begin{array}{l}\text { Module price } \\
(\$ / W)\end{array}$ & $\$ 0.15$ & $\$ 0.18$ & $\$ 0.19$ & $\$ 0.17$ & $\$ 0.19$ & $\$ 0.18$ & $\$ 0.10$ & $\$ 0.29$ & $\$ 0.18$ \\
\hline & System cost $(\$ / W)$ & $\$ 0.69$ & $\$ 0.69$ & $\$ 0.69$ & $\$ 0.69$ & $\$ 0.69$ & $\$ 0.69$ & $\$ 0.69$ & $\$ 0.72$ & $\$ 0.68$ \\
\hline & Efficiency at STC & $23.0 \%$ & $25.0 \%$ & $26.0 \%$ & $25.0 \%$ & $26.0 \%$ & $25.0 \%$ & $20.0 \%$ & $35 \%$ & $28.0 \%$ \\
\hline & $\begin{array}{l}\text { Power } \\
\text { temperature } \\
\text { coefficient }\left(\mathrm{K}^{-1}\right)\end{array}$ & $-0.35 \%$ & $-0.25 \%$ & $-0.30 \%$ & $-0.40 \%$ & $-0.25 \%$ & $-0.30 \%$ & $-0.40 \%$ & $-0.20 \%$ & $-0.20 \%$ \\
\hline & Efficiency at $50^{\circ} \mathrm{C}$ & $21.0 \%$ & $23.4 \%$ & $24.1 \%$ & $22.5 \%$ & $24.4 \%$ & $23.1 \%$ & $18.0 \%$ & $33.3 \%$ & $26.6 \%$ \\
\hline & $\begin{array}{l}\text { Degradation rate } \\
\text { (\% per year) }\end{array}$ & $0.40 \%$ & $0.40 \%$ & $0.40 \%$ & $0.40 \%$ & $0.40 \%$ & $0.40 \%$ & $0.40 \%$ & $0.30 \%$ & $0.50 \%$ \\
\hline
\end{tabular}

STC $=$ standard test conditions.

Note: Efficiency of bifacial architectures is increased by $8 \%$ to account for rear-side energy yield.

Table A-2. LCOE Values Represented on TEF Plots (cents/kWh)

\begin{tabular}{|l|c|c|c|c|c|c|c|c|c|}
\hline & $\begin{array}{c}\text { Mono } \\
\text { PERC }\end{array}$ & $\begin{array}{c}\text { Bifacial } \\
\text { PERC }\end{array}$ & si-IBC & $\begin{array}{c}\text { Bifacial } \\
\text { PERT/PERL }\end{array}$ & $\begin{array}{c}\text { Bifacial } \\
\text { SHJ }\end{array}$ & CdTe & CIGS & III-Vs & Perovskites \\
\hline 2010 & 15.0 & 19.9 & 12.5 & 19.8 & 14.7 & 10.5 & 8.8 & $\$ 8.11$ & $\$ 8.62$ \\
\hline 2020 & 4.4 & 4.7 & 4.1 & 4.7 & 4.6 & 4.6 & 5.6 & $\$ 3.66$ & $\$ 4.00$ \\
\hline 2030 & 3.0 & 3.0 & 3.0 & 3.0 & 3.0 & 3.0 & 3.0 & 3.0 & 3.0 \\
\hline
\end{tabular}

